University of San Diego

Digital USD

1986

\title{
An Analysis of Perceptual Differences and Congruities between California Community College Chancellors and Presidents in Multi-College Districts Regarding the Decision-Making Role of the Presidents
}

Jeanne Davis Atherton EdD

University of San Diego

Follow this and additional works at: https://digital.sandiego.edu/dissertations

Part of the Leadership Studies Commons

\section{Digital USD Citation}

Davis Atherton, Jeanne EdD, "An Analysis of Perceptual Differences and Congruities between California Community College Chancellors and Presidents in Multi-College Districts Regarding the Decision-Making Role of the Presidents" (1986). Dissertations. 485.

https://digital.sandiego.edu/dissertations/485

This Dissertation: Open Access is brought to you for free and open access by the Theses and Dissertations at Digital USD. It has been accepted for inclusion in Dissertations by an authorized administrator of Digital USD. For more information, please contact digital@sandiego.edu. 


\title{
AN ANALYSIS OF PERCEPTUAL DIFEERENCES AND CONGRUITIES BETWEEN CALIFORNIA COMMUNITY COLLEGE CHANCELLORS AND PRESIDENTS IN MULTI-COLLEGE DISTRICTS REGARDING THE DECISION-MAKING ROLE OF THE PRESIDENTS
}

\author{
By \\ Jeanne Davis Atherton \\ A dissertation submitted in partial fulfillment \\ of the requirements for the degree of \\ Doctor of Education \\ University of San Diego
}

1986

Dissertation Committee

Wallace Cohen, Ed.D., Director

William Foster, Ed.D. Susan Zgliczynski, Ph.D. 
(C) Copyright 1986

Jeanne Davis Atherton

All Rights Reserved 
AN ANALYSIS OF PERCEPTUAL DIFFERENCES AND CONGRUITIES BETWEEN CALIFORNIA COMMUNITY COLLEGE CHANCELLORS AND PRESIDENTS

IN MULTI-COLLEGE DISTRICTS REGARDING THE

DECISION-MAKING ROLE OF THE PRESIDENTS

ATHERTON, JEANNE DAVIS, Ed.D. University of San Diego, 1986

Director: Wallace Cohen, Ed.D.

$167 \mathrm{pp}$.

\section{Purpose}

This study was designed to provide foundational information concerning the perceptions of California community college chancellors and presidents in multi-college districts, regarding the presidents' decision-making role, at both the college and districtwide levels. Factors pertaining to the chancellors and presidents' professional background, and to district characteristics were reviewed for possible relationships to perceptual congruities and differences. Methodology

Survey research methodology provided the basis for the design of the study. Eleven district chancellors and 28 presidents responded to a 24 item, two level Likert-type instrument and a professional background questionnaire. Demographic information on each of the participating districts was obtained and used in the analysis. 
Standard t-tests and chi-square analysis were used to determine if there were differences in responses of chancellors and presidents overall, by functional category and for each item at the college and districtwide levels of decision-making. The professional background questionnaire and district profile provided anecdotal information with which to compare the statistical findings. Findings and Conclusions

Some of the major findings and conclusions of the study were as follows:

1. Chancellors and presidents in California multicollege districts agreed that presidents have a great deal of decision-making autonomy at their own colleges.

2. The presidents' decision-making involvement at the district level is ambiguous and in need of clarification.

3. Some relationship can be drawn between the professional background of the chancellors and presidents and the congruence and discrepancies of their perceptions.

4. District size, age, central office location, and administrative reporting relationships do not appear to be related to perceptual differences.

\section{Recommendations}

A major recommendation of this study is that the presidents' decision-making role at the district level be formalized in their position descriptions. In addition, a similar study should be undertaken in large urban multicollege districts. Some attention should be given to 
factors such as leadership style, organizational culture, collective bargaining, and the politicizing of districts that might influence the presidents' decision-making role. 


\title{
DEDICATION
}

to my mother,

Mabel Reed Davis
a liberated lady - long before the fashions came - who loved me, taught me, encouraged me, and convinced me to reach for the stars - her influence will be with me always.

\author{
and \\ to my husband, Larry \\ who would never let me give up - \\ and whose love is equaled only \\ by his dogged determination \\ to support me in every \\ endeavor.
}




\section{ACKNOWLEDGEMENTS}

Special appreciation is extended to all of the following:

... To Ray Gorden, who spent a day of his vacation to review the design of the study and to offer invaluable suggestions.

... To Curt McCarty and Lynn Neault, who assisted me with the statistical aspects of the study, and without whom I would still be pouring over computer printouts.

... To my dissertation committee, Wally Cohen, Bill Foster, and Sue Zgliczynski, who offered advice, support and encouragement.

... To the San Diego Community College District for providing the inspiration for the dissertation topic.

... To the University of San Diego for its strong commitment to human and ethical values.

Thank you, all. 
DEDICATION . . . . . . . . . . . . . . . . 
Advantages and Disadvantages of

Multi-Unit Systems . . . . . . . 27

Locus of Control in Multi-Unit Districts . . 29

Centralization and Campus Autonomy . . . 30

Summary • • • • • • • • • • • • 37

Leadership Roles . . . . . . . . 38

Role Delineation . . . . . . . . 38

Building Relationships . . . . . . . 42

III. RESEARCH DESIGN AND METHODOLOGY . . . . . . . 46

Design of the study . . . . . . . . . 46

Selection of Sites for Data Collection . . . 47

Selection of Subject Population . . . . . 49

Instrumentation . . . . . . . . . . 49

Role Perception Questionnaire . . . . . 50

validity . . . . . . . . . . 54

Reliability . . . . . . . . . . 54

Professional Background Questionnaire . . . 54

District Profile Sheet . . . . . . . . 56

Data Collection . . . . . . . . . 56

Confidentiality . . . . . . . . 56

Data Collection Procedures . . . . . 57

Hypotheses . . . . . . . . . . . 58

Data Analysis . . . . . . . . . . . 59

Procedures: Hypotheses 1, 2, 3 . . . 59

Procedures: Hypotheses 4 . . . . . . 60

Anecdotal Information and Literature 62

V 
IV. ANALYSIS OF DATA . . . . . . . . . .

Introduction ............... 63

Role Perception Questionnaire . . . . . 63

Hypotheses 1, 2, 3, and Findings . . . 64

Additional Analysis of Statewide

Data............. . 70

Hypothesis 4 and Findings . . . . . . 71

Professional Background Questionnaire . . . 80

Analysis of Chancellors' Responses . . . 80

Analysis of Presidents' Responses . . . 82

District Profile sheet . . . . . . . 85

District Size . . . . . . . . . 85

District Age . . . . . . . . . 86

District office Location . . . . . . 86

Administrative Reporting
Relationships . . . . . . . . . 86

Summary • • • • • • • • • • • • 87

Statewide Findings . . . . . . . . 87

Individual District Findings . . . . . 88

V. DISCUSSION OF FINDINGS, CONCLUSIONS AND

RECOMMENDATIONS • • • • • • • • • • • 92

Nature and Purpose of Study . . . . . . 92

Discussion of Findings . . . . . . . . . 94

Differences and Congruities:

Differences and Congruities:

Individual Districts . . . . . . . . 97

Conclusions . . . . . . . . . . 102

Implications of the study . . . . . . 103

vi 
Recommendations for Future Studies . . . 106 REFERENCES • . . . . . . . . . . . . . . . 162 
Table

Page

1. Chancellors and Presidents

Perceptions statewide . . . . . . . . .

2. Chancellors and Presidents Perceptions

Statewide by Category . . . . . . . 66-67

3. Chi-Square Significance Statewide by Item . • 69

4. Item Discrepancies by District . . . . . . . 72

5. Multi-College Districts with Operationally

Significant Discrepancies in the

"External Relations" Category at the

College Level, and Years of

Administrative Service . . . . . . . . 74

6. Multi-College Districts Exceeding 25\%

Discrepancies on Items at the

Districtwide Level, and Years of

Administrative Service . . . . . . . . . 


\section{LIST OF FIGURES}

Figure

Page

1. Representative Organization of

a Multi-College District . . . . . . . 3

2. Paradigm: Continuum of Multi-Unit

Development in the Junior College...... 20 
Appendix

Page

A. California Senate Bill SB 2064 . . . . . . . 111

B. Survey Instruments . . . . . . . . . . 115

C. Cover Letter for Survey . . . . . . . . . . 128

D. Statistical Computations . . . . . . . . 131

E. Chancellors' and Presidents' Years

of Administrative Experience in

Multi-College Districts . . . . . . . . . . 159 
Even in districts that have sought to provide maximum autonomy to campus units by calling them colleges and by providing the chief executive with the title of president, there is still a constant tension accompanied by the ever-present realization that the needs and priorities of the system take priority over the aspirations of the individual units.

(1972, Richardson, Blocker and Bender, p.125) 


\title{
Chapter I \\ STATEMENT OF THE ISSUE
}

\begin{abstract}
Background
Community colleges in America had their beginnings as junior colleges in the first part of the twentieth century. Since the $1930^{\prime}$ 's when approximately 450 colleges first achieved their community-based identity, their numbers have grown to approximately 1,200 with enrollments totaling close to $5,000,000$.

The philosophy underlying the community college movement was that community colleges were to be available to the people at little or no cost. Their purpose was to provide the first two years of undergraduate instruction for those wishing to transfer to four-year institutions, and to provide occupational training for those who did not. Community colleges opened the doors of postsecondary education to the middle and lower socioeconomic population of the American society, including under-represented minorities.

Community colleges reflect the diversity of the population within their communities. Some serve a large number of older adults and retired persons; still others serve a more traditional student clientele
\end{abstract}


interested in transfer (Commission for Review of the Master Plan for Higher Education, 1986a, p.2). Just as the present two year colleges are characterized by the diversity of their student bodies, their curricula, their locations, their size and their financing; so is diversity a cornerstone of their organizational structures. Although most community colleges in America are organized as single college districts - that is, one chief executive officer and a locally elected board of trustees that establishes policy - others, due in major part to the expansion of branch campuses or centers into comprehensive programs requiring their own administration, have formed multi-unit districts that encompass two or more campuses. Excluding statewide systems, there are now approximately 100 such districts as contrasted with only ten 20 years ago. In those 100 districts are more than 350 campuses (Jensen, 1984). Generally speaking the administration of multi-unit districts is far more complex than that of single college districts.

The two most common organizational structures for multi-unit districts are the single college multi-campus structure which remains a single legal entity with one catalog, one president and two or more campuses, and the multi-college structure with two or more separately accredited comprehensive colleges, each with its own catalog and a president who reports to a district CEO (Figure 1). 
Representative Organization of a Multi-College District

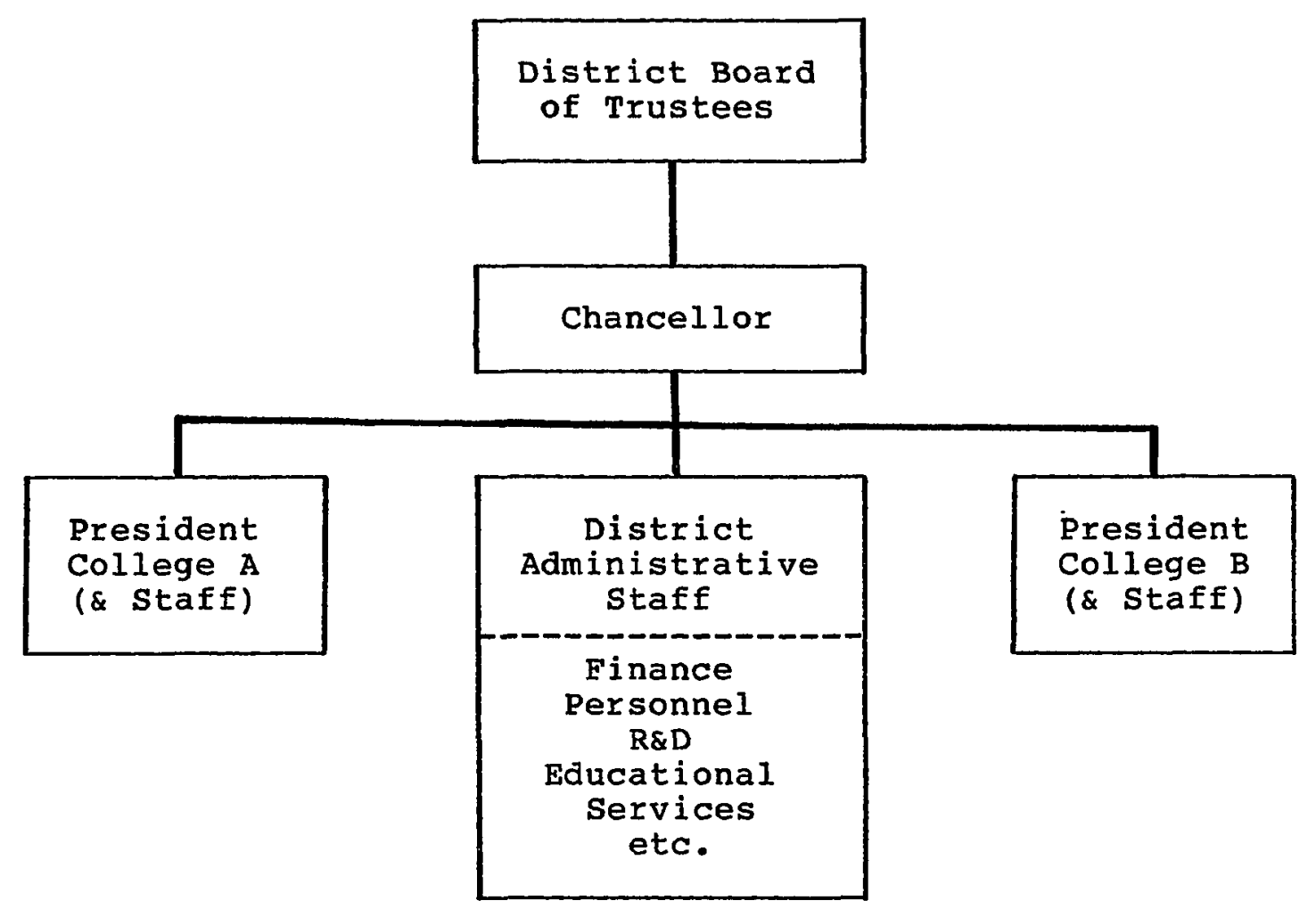

Figure 1. 
While there are now community colleges in every state which nationally enroll half the students who begin college (Cohen and Brawer, 1982), the historical leader in the development of community colleges was California (Bogue, 1950). By the late 1970 's California community colleges had become the largest college system in the country, chiefly as a result of expanded educational opportunities for that segment of the population that had not previously had access to postsecondary education. Governance of California Community Colleges

From their beginnings in 1907 to the present time, each district has been governed by its own locally elected board of trustees; a governance structure that is unique and somewhat cumbersome. The $106 \mathrm{California}$ community colleges are divided into 70 districts, 18 of which are multi-college systems governing 53 separately accredited colleges. With the exception of Los Angeles, with its nine colleges, by the end of 1986 no community college district in California will govern more than three colleges.

Since the passage of Proposition 13 in 1978, which severely limited the authority of community college districts to secure local tax revenue, the state has financed approximately $70 \%$ of community college expenditures. With the community colleges becoming the largest state-supported system of postsecondary education in California, the legislature has questioned whether it is appropriate to have such a system accountable to local 
boards rather than to the state.

In 1985, the California legislature created a commission to revise the 1960 Master Plan for Higher Education, which had set the course for the mission, structure, and governance of higher education in California. Following that action, Senate Bill 2064 (Stiern, 1985) became law. That bill required the commission to reassess community colleges as its first priority. Clearly the California legislature had become intimately involved in the affairs of the local districts.

In addition, the State Board of Governors for community colleges, a board appointed by the Governor, mandates regulations that local boards must obey. Each district has its own locally elected Board of Trustees responsible for managing and setting policy for that district. Recently, however, the state Chancellor, who reports to the Board of Governors, has attempted to take a far more active role in setting the course local districts should follow.

Local California community college districts, with their diversity of programs and local governance policies are under a great deal of scrutiny. Some see state control with regional boards of trustees as a way to "bring the system under control." Other stress the necessity of maintaining locally autonomous districts sensitive to the educational needs of their constituencies.

Among the recommendations regarding community college governance made to the legislature was the following: 
That the Board of Governors conduct a thorough review of all statutes affecting the administration and operation of the community colleges, and recommend to the legislature the amendment or repeal of those provisions regarding the management of the districts and colleges that have become obsolete in light of the increased authority being granted to the Board of Governors and of the clear postsecondary role of the colleges (Commission for Review of the Master Plan for Higher Education, 1986b, p.100).

The controversy surrounding the governance issue finds colleges within multi-college districts faced with the potential of even more centralization vis-a-vis the Board of Governors. Most multi-college districts are already large, and even if they do not grow at the same rates they did in the previous decade, they show few signs of diminishing in size. While there is evidence that neither a highly centralized nor highly decentralized distribution of authority is a primary determinant of institutional effectiveness in multi-unit community college systems (Jenkins and Rossmeier, 1974), there is the risk of depersonalization, ambiguity, and avoidance of responsibility within highly centralized systems (Kintzer, 1972). As a result, questions of major importance emerge including: Who has what decision-making role in multicollege districts? Are the components of the division of that power clearly understood by campus and district heads? 
What effect does the division of decision-making responsibilities have on the working relationships among the campus presidents and the district chancellor? Decision-Making in Multi-Unit Districts

Wattenbarger in 1977, indicated that there was a scarcity of both theoretical and applied knowledge about decision-making in multi-unit districts. Other studies that probe the types of decision-making in multi-unit districts are descriptive in nature, focusing on which decisions are made at what levels. Most of these studies, however, use small sample sizes, thus making generalizations difficult. The decision-making role of college presidents in multi-college California community college districts is not clearly defined. Unlike the presidents in single college districts who are also district superintendents, college presidents in multi-college districts are one level removed from the governing board and have limited legal status under California Education code. The code grants the superintendent/chancellor of each district the legal authority to prepare and submit the budget, to assign and transfer employees, and to enter into contracts on behalf of the district. The district chancellor reports, and is accountable to, a district board of trustees which is responsible for the management and control of that district. The chancellor then, is the chief administrative officer of the district, and is given the legal authority to implement board policies and procedures. 
In a single college district the president is tile spokesperson for the college, coordinates all aspects of the college program, meets with the board, attends state and national meetings, and handles relations with state agencies, and the community (Cohen and Brawer, 1982, p.111). In a multi-college district, however, it is the chancellor who has that authority and who delegates any portion of it to the college presidents. As a result, the decision-making authority and influence of college presidents within a multi-college district may be partially dependent upon the district chancellor's managerial style, and on his or her perceptions of what the presidents' role should be.

A communications audit conducted by the Management Association of the San Diego Community College District (1982) identified specific areas of concern between middle and upper level management. Lack of role definition and uncertainty about who had what decision-making authority were key findings of the study.

Yukl (1981) sees one condition for acceptance of a leader's authority as the "perceived legitimacy" of the person in the leadership role (p.19). Where a leader's scope of authority may be formalized in a position description, there may still be considerable uncertainty about the extent of his or her actual decision-making involvement within the organization.

An earlier study conducted by Buckner (1975) concluded that an effective management system in a multi-unit 
community college district is influenced by factors that go beyond its organizational structure. One important factor is the personal leadership style of the chief executive officer. Buckner called for further examination of the role and interrelationships of campus and unit college chief executive positions. "The role of the individual unit chief executive officer is in need of clarification" (p.168). Baldridge (1971) developed a political paradigm of the leader as a change agent in academic institutions during periods of turmoil and change. Baldridge found that at such times, formal authority decreased in effectiveness while personal influence, bargaining, political pressure and negotiated compromise emerged. The chief administrator of a college, if he or she is to effect change,". . must also be effective as a leader, mediator, negotiator, statesman, entrepreneur, and overall manager" (Richman and Earmer, p.166). In other words, the personal influence of the presidents and their ability to move the system enhances their leadership role. The ability of a president to practice such leadership within a multi-college district, whether at his or her college or districtwide, is suspect. A major problem emerges in the delineation of power of college presidents in multi-college districts. Their roles are delimited by the hierarchy in which they serve, and by that authority delegated by the system chancellor. The professional life of a college administrator in a multi-unit district is sometimes devoted to seeking those areas over 
which he or she has authority or influence (Dressel, 1981).

In 1977, Olswang established a connection between dissonance of administrative role perceptions and organizational inefficiency in institutions of higher education.

There is reason to conclude, based upon these studies and others including early works by Gordon (1955), Likert (1961) and later by Rossmeier (1976), whose work pertained directly to multi-unit districts, that an important factor in organizational effectiveness is the amount of influence individuals felt they had in the organization. In other words, the effectiveness of a multi-unit district may increase when the constituents of that district perceive they are directly involved in the decision-making process. If there is a difference between the district chancellor's perceptions of the college presidents' decision-making role and the college presidents' perceptions of that role it may cause confusion and ambiguity about the values held concerning the presidents' scope of authority, thus resulting in significant organizational dysfunction.

\section{Problem Statement}

Due to the unique organizational structure of California multi-college districts where each college president reports to a chancellor, there appears to be a great deal of uncertainty about the decision-making role of the presidents. Unlike their colleagues in single-college 
districts, they are one step removed from the district's governing board, and must share in decision-making activities at both the college and districtwide levels. The problem to be examined in the study was whether chancellors and presidents within multi-college districts differ in their perceptions of the presidents' decision-making role, and if so, what factors contribute to these differences.

\section{Purpose of the study}

The purpose of the study was to examine and analyze the perceptions of the chief executive officer (chancellor) and college presidents of multi-college community college districts relative to the decision-making involvement these presidents have in certain major functional areas at their college and districtwide. The areas selected were based upon the presidents' position descriptions and the work of Buckner (1975) who delineated broad categories of decision-making functions by presidents in multi-college districts.

The information gained from identifying and analyzing the data will form the basis for future research. Such studies can examine more closely the relationship between perceptual differences and congruities of the presidents' decision-making role and organizational effectiveness. 
The research questions that were examined in this study are:

1. Will there be differences statewide between the district chancellors' and college presidents' perceptions of the presidents' decision-making involvement at the college and district levels? Will there be differences within each multi-college district?

2. Within which decision-making functional areas, and at what level are there differences between multi-college district chancellors and college presidents?

3. What external factors pertaining to the professional background of the respondents, and district characteristics might help explain congruities or differences in perceptions?

This study focused upon the match between the perceptions of the presidents and chancellors in California multi-college districts statewide and in each district. Thus a district where both the chancellor and the presidents perceived the presidents' decision-making involvement be minimal at the college level showed the same congruity as one in which both the chancellor and presidents perceived that decision-making involvement to be very strong.

The Premise of the Study The premise of the study was that congruence of 
perceptions between the chancellor and presidents in a multi-college district raises the level of those perceptions to shared values, which in turn are transformed into a strong operational philosophy.

The chancellor, as legal head of the district has convictions about the nature of reality in that district. These convictions become the district's assumptions. If these assumptions are challenged, debated, ignored or misunderstood by the presidents, they cannot be embedded in the organization as shared values, and as a result cannot form the basis of a strong operational philosophy. If on the other hand, the assumptions are clearly communicated through the organization by the chief executive officer and his or her top level administrators, it is more likely that the resultant values will serve as a unifying force to bring the group together toward a common mission.

\section{Definition of Terms \\ Comprehensive community college. Any institution} accredited to award the associate in arts or science as its highest degree (Cohen and Brawer, 1982).

Multi-unit district. A community college district operating two or more campuses within its district under one governing board. Each campus has separate site administrators. Multi-unit districts may be multi-campus or multi-college. 
Multi-campus district. A community college district operating as one legal institution with two or more campuses, one accreditation, one catalog and one president. This type of organization is also identified in the literature as a multi-branch district.

Multi-college district. A community college with two or more separately accredited comprehensive colleges each with its own catalog and president, and a district organization headed by a chancellor.

District chancellor or superintendent. The legal head of a multi-college district reporting directly to its governing board.

College president. The highest administrative level position at a college within the multi-college district. "Typical" multi-college district. A community college district governing no fewer than two, nor more than three, colleges.

Decision-making areas or categories. These include planning, finance, communication of policies and decisions, external relations, educational leadership and evaluation. College and districtwide levels of involvement. College involvement refers to a significant decision-making role at the college level. Districtwide involvement refers to a significant decision-making role within the entire district organization, including the other colleges and centers within the district, and the central office. 
Limitations and Delimitations

The following factors posed limitations to this study:

1. All generalizations applied only to the presidents and chancellors of the colleges participating in the study. 2. The generalizations and implications of this study were dependent upon the willingness of individuals to respond trutheully and in a timely manner; and on the accuracy of the data provided in response to the questionnaires. The study was delimited to the following:

1. The investigation included 14 of the 18 California multi-college districts. Each of these districts governs no less than two, nor more than three colleges. Large urban multi-college districts were not included in the study. 2. The collection of data was limited to a Role Perception Questionnaire, a Professional Background Questionnaire and a District Profile Sheet.

3. Only college presidents and chancellors of multi-college districts were asked to respond to the Role Perception Questionnaire and Professional Background Questionnaire. 4. The list of presidential functions was drawn from the literature and position descriptions. The list is not intended to be exhaustive. 5. The areas in which data was to be collected on the District Profile sheet were drawn from the literature. 6. The study recorded perceptions of presidents and chancellors. These perceptions of the presidents' decision-making involvement were not always congruent with 
the actual responsibilities 1 isted on the presidents description positions.

7. The study was limited to California to ensure like governance structures and laws limiting the authority of presidents in multi-college districts. In California, the legislative body and the state Board of Governors set policies and regulations statewide, while locally elected boards of trustees are responsible for managing and setting policies for their individual community college districts. 
Chapter II

REVIEW OF LITERATURE

Introduction

The purpose of this literature review is to provide background into the organizational structure of multi-unit districts and the issues confronting these districts. The premise of any multi-unit district is that three major principles are foundational to their effectiveness (Jensen, 1984):

1. There must be efficiency of programs and services.

2. There must be consistency of policy and practice districtwide.

3. Campus initiative to innovate and demonstrate leadership must be encouraged.

An extensive search of the literature was conducted using both manual and computerized data base systems. Many of the studies in the area of community college multiunit districts were conducted in a 10 year period after the work of Axthur Jensen in 1965. Both the University of Florida and the University of California at Los Angeles have produced a number of dissertations, articles and unpublished reports in this area. It must be noted, however, that there is a scarcity of research dealing with this field. As a 
result, the researcher expanded the search to include all multi-unit systems in higher education (i.e., universities with branch campuses) and large public school systems. Although the former provided useful information for this study, few parallels could be drawn between multi-unit districts and public school systems.

The literature focuses on the multi-unit organizational structure, issues of centralization and factors that influence the decision-making process in multi-unit community college districts. The first two areas tend to be descriptive in nature, reporting on patterns that have been observed through case studies. The third area concentrates on the leadership problems inherent in these complex organizations.

In an effort to build upon this research, this study suggests that, to be effective, multi-college organizations must focus upon the notion of a shared relationship between colleges and districts, with its leaders understanding not only districtwide goals and priorities, but the issues unique to a multi-unit organizational structure that may impact on the decision-making process.

Organizational structure of Multi-Unit

College Districts

In a 1965 landmark study on multi-unit community college districts, Arthur Jensen described the various types of multi-unit organizational structures: 
1. Multi-college district - a district operating two or more individual comprehensive colleges.

2. Multi-branch (multi-campus) district - a district operating a single legal institution with two or more comprehensive campuses.

3. Multi-program district - a district similar in organization to multi-branch districts except that each branch (or campus) offers a different educational program; for example, a technical and vocational program on one campus, and arts and sciences on another.

Within the multi-unit organizational pattern emerged two distinct structures. First is the multi-branch or multi-campus district which operates as one legal institution with two or more branches or campuses. These districts typically have one catalog and a president in the central office. The second is the multi-college district which governs two or more individual comprehensive colleges, each with its own president, administrative staff, and catalog.

The multi-college structure according to Jones (1968) frequently evolves from the branch or campus structure, when, as branch campuses become more comprehensive, they also move toward more autonomy. Jones saw the type of organizational structures as a function of the phase of development of the district. Figure 2 illustrates the stages of growth in multi-unit systems. 
PARADIGM

Continuum of Multi-Unit Development in the Junior College

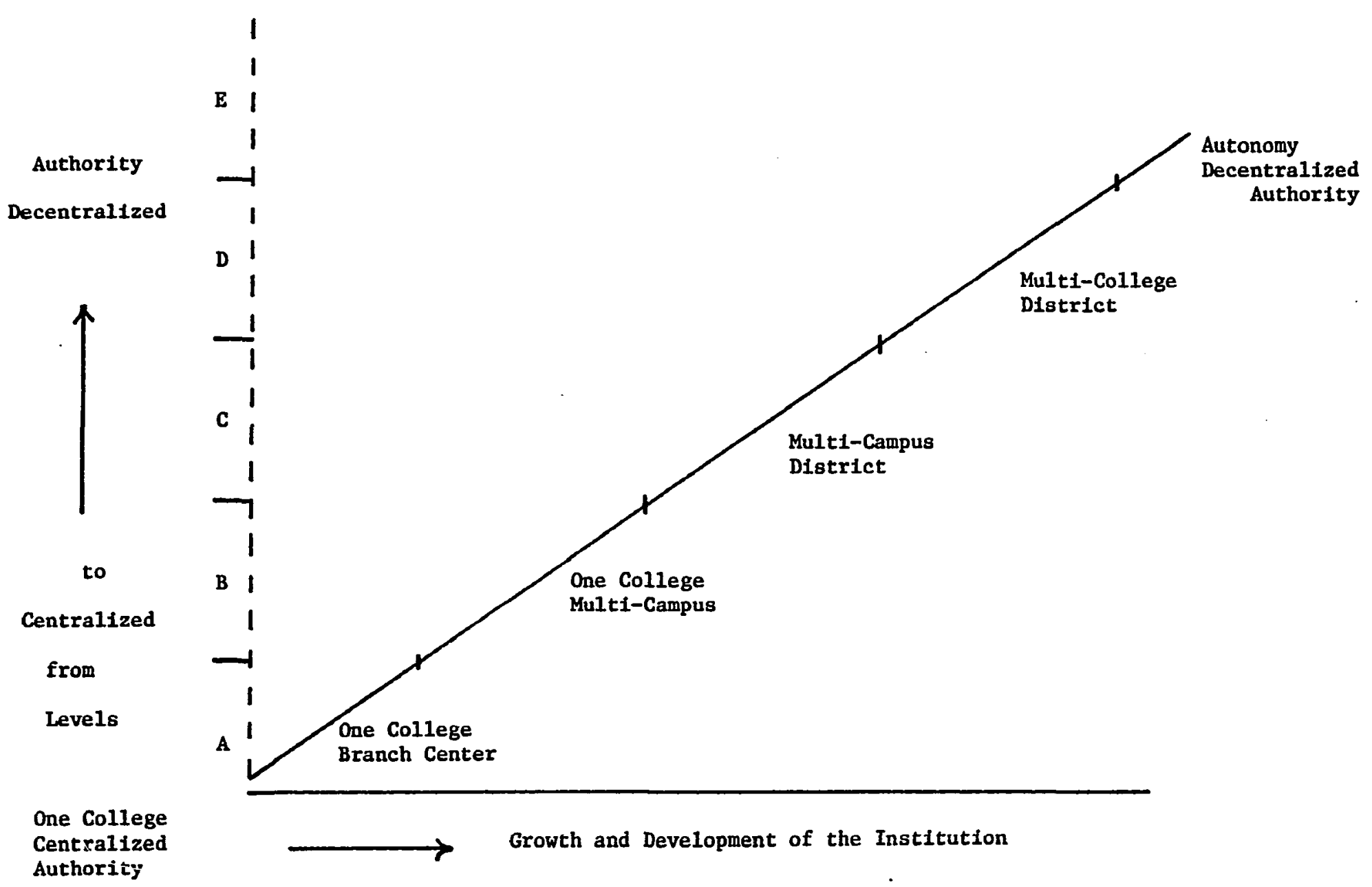

Figure 2 (Jones, 1968) 
In discussing his paradigm, Jones indicated:

Generally one institution develops off-campus centers to better fulfill its role as an educational institution, level A. As these centers grow, they begin to take on the functions of separate campuses, which is denoted on the paradigm as level B. As the single campus develops its own administrative organization and takes on many of the separate functions and services, it becomes a somewhat more autonomous organization. This leads to a de-emphasis of the one college aspect of the separate campuses and tends to view the campus as more independent members of a broadly defined district, level c. Certainly, as the multi-campus institutions within a district become stronger and more self=supporting, the natural step is toward multi-college districts, level D (pp.28-29). Jensen (1965) recommended in his study that each campus in a multi-unit district be given as much decision-making authority as the district can provide.

Under this plan, the decision-making process is placed close to the people who have at hand, the facts on the basis of which decisions can be made. These same people are responsible for carrying out decisions (p.163)

Jensen limited his comments to the campus level and did not discuss how that decision-making role relates to districtwide decision-making. 
Chang, (1978), however, was not convinced that Jensen's formula for success was quite so easy to derive.

organizational structures are a function of factors such as political, economic, and community environment; size of enrollment, number of campuses, dispersion of campuses; and the prevailing educational and administrative philosophy (p.3)

Operational Guidelines

In 1969, Kintzer, Jensen and Hansen studied 45 multi-unit districts in 17 states. While they found there was no one best organizational structure they did suggest operational rules designed to ensure harmonious relationships between the district office and the colleges within the districts.

District leve1. Guidelines suggested for the district office include:

1. That a chancellor represent the board of trustees and be responsible for general administration of the entire district.

2. That the central office have at least three administrative positions besides the chief administrator (chancellor), specifically in the areas of business affairs, instructional programs, and semi-professional education.

3. That the central office be located completely away from all campuses, preferably at a location central to the entire district. 
4. That no one at the central office, other than the chief administrative officer of the district, be at a level higher than that of the chief campus administrators (pp.51-52).

College level. Guidelines governing the effectiveness of colleges within multi-unit districts include:

1. That each campus have as much autonomy as possible.

2. That experimentation on the campus level be encouraged and supported.

3. That each campus be allowed to hire its own personnel.

4. That the people hired for the positions of chief administrators on the campuses agree with the philosophy of the organization as decided by the board of trustees.

5. That the right type of chairman be chosen for a department within the college.

6. That teachers and administrators have mutual respect for each other's responsibilities and competencies.

7. That leadership is a crucial factor in the success or failure of a district system (p.53).

The authors recommendations serve as organizational guidelines for multi-unit districts, although the data used in the analysis was obtained in most part from multi-college rather than multi-campus districts (pp.49-52). 
This study is perhaps the most influential study of multi-unit community colleges, since it focuses on the relationship between the district office and its campuses. The major conclusion of the study is that shared authority is both prevalent and desirable.

Comparing the Multi-Campus and Multi-College Structures

In 1975 Wattenbarger and Holcombe conducted a national survey of multi-campus and multi-college community college districts in an effort to clearly delineate the two types of organizational structures. They found that:

1. Multi-college districts reported permanent locations more often than did multi-campus districts.

2. Multi-campus district utilize only one-third the number of off-campus instructional facilities than do multi-college districts.

3. Ninety-two percent of multi-college districts studied had their district offices off campus.

4. Central administrative functions were similar in both kinds of districts.

5. Although multi-college districts tend to be larger than multi-campus districts, the central office of the latter retain more staff (pp.23-25).

Wattenbarger and Holcombe concluded that since the larger districts have fewer administrative staff members a lessening of district office control may be inferred. 
The authors asked a number of questions as they compared the results of their study to some previously described. Although most conclusions are consistent with Jones' development continuum, there was in the authors' minds at least one notable exception, Miami-Dade College in Florida. It is not only one of the largest multi-campus districts, it is the largest community college in the eastern United States. The authors questioned why it had not moved from a multi-campus to a multi-college structure since it is in a mature development phase. This may have more to do with the Florida higher education system than any philosophical or evolutionary trend. By state law, Florida does not allow districts to have more than one president. Arthur Jensen in a 1984 update of his 1965 study used Miami-Dade to reinforce Jones' continuum. Jensen, in fact, referred to Miami-Dade as a multi-college district despite its legal status as one institution with branch campuses. In comparing it to California and other systems:

The writer believes that Florida multicampus districts have the best of both worlds, at least those visited. Each multi-college district has one president and operates as one legal institution, with one accreditation, one catalog, one class schedule; yet the great majority of their campuses are comprehensive. The chief campus administrators are obtaining more autonomy in the operation of their campus with the opportunity to be innovative and try new ideas (p.14). 
Since Jensen's 1965 study, the trend toward multicollege districts has slowed considerably. The 1980's have seen enrollment declines and a resultant facultyadministrative retrenchment. Scigliano (1981) reported that since the system has reached a plateau, it will experience only limited growth through the next decade, resulting in a need for new organizational strategies and structures. In California alone, one college changed from a multi-college district with a chancellor and two college presidents to a multi-campus district with a district president and a provost at each campus. Another college district changed the title of one of their campus chief administrators from president to executive dean. A third now has a president only in the smaller of its two campuses, while the chief executive officer of the district has also become president of the larger campus (Jensen, 1984). Organizational Dysfunction

The development and growth of multi-unit districts were based upon the need to provide educational services to all segments of the community. Although it's clear that such districts serve a valuable function, the complexity of the organization and rivalries between the central office and campus officials, can result in dysfunctional management. The multi-unit type of organization in higher education was described a decade ago as one of the reasons for the acceleration of homogeneity among universities and colleges, the diminuation of individual campus 
identity, erosion of the chief executive's role and the encouragement of the rise of systemwide interest groups as independent kingdoms. These conditions, it was concluded, led inexorably toward politicization of the entire system (Kintzer, 1984, p.1).

Studies concerning organizational size and complexities suggest that the greater the organization's size the greater the centralization of authority to enable the organization to keep sight of its overall goals (Evan, 1966). According to Bennis and slater (1968) the result of this hierarchical structure is that employees become alienated, relationships become depersonalized and organizational procedures become bureaucratic. Rosalie Hill (1985) suggests that as the organizational structure becomes more complex, task uncertainty increases and rules become more inflexible. Advantages and Disadvantages of Multi-Unit Systems

In general, all researchers agree that the multi-unit organizational system has its good and bad features. A summary of these, that are applicable to this study are as follows:

\section{Advantages:}

1. Multi-unit districts can better serve a large geographic area than can a single college. This makes access easier for the population within that area.

2. By having more than one campus it is possible to meet the diverse needs of various segments of the 
community, through specialized courses and programs.

3. By having a number of campuses, each campus can be kept to a reasonably manageable and functional size.

4. There is a potential for more efficiency since the multi-unit structure is designed to avoid costly duplication of programs and services.

Disadvantages:

1. Size and complexity of the multi-unit district make it not well suited to change and innovation.

2. Community identification with the district is more difficult to achieve.

3. Operating costs are greater especially during the first few years.

4. There may be dysfunctional competition among the campuses in the district.

5. One campus may become oriented toward vocational or "blue collar" programs and another campus toward only college transfer programs, thereby promoting possible social stigmas.

There is no question the multi-unit district is here to stay. The pattern of organization within those districts, however, can play an important part in maximizing the strengths and minimizing the weaknesses in the structure. 
Locus of Control in Multi-Unit Districts

organization charts and rational approaches to delineation of authority in complex organizations do not adequately describe how the locus of control of these organizations is defined nor how it impacts on organizational units.

Some researchers, including contingency management theorists Lawrence and Lorsch (1967) have suggested that the size of an organization makes it difficult for the organization to act as an integrated whole. The larger the organization, and the more it differentiates functions, they claim, the more difficult it is to create relationships between parts. The authors suggested that subunits within a large organization operate in different environments. An organization such as a large multi-college district with great diversity among its units, would find it more difficult, therefore, to behave as a single entity through the integration of the units. In addition, the more unstable the environment, the more complex the organizational structure must become.

A leading organization culturist, Edgar Schein (1985), indicates that as an organization matures and expands there may be a loss of integration within the organization. He argues, however, that uniformity or diversity are neither good nor bad in themselves. The issue as he sees it is more in managing whatever pattern develops. 
Centralization and Campus Autonomy

An issue of major importance in analyzing the locus of control in multi-college systems deals with the balance between campus autonomy and centralization of decisionmaking functions. There have been a number of studies that have examined this issue as it pertains to multi-unit systems in higher education.

A study conducted by Jones in 1968, indicated that as multi-unit districts evolve and grow in size and complexity, they move toward increased campus autonomy. This was confirmed in a number of later studies including those by Kintzer (1969 and 1984), Wattenbarger and Holcombe (1975) and Henry and Creswell (1983). This notion was extended to the university setting by Baldridge (1973):

Larger colleges and universities showed a strong trend toward faculty autonomy. Larger institutions had more complex tasks and were divided into more specialized units with highly trained experts with power to demand autonomy. Larger schools had less centralization of decision-making; fewer bureaucratic regulations; more department and individual autonomy and greater production from outside demands (p.4).

Buckner, writing in 1975, refuted Jones' and Baldridge's findings; concluding instead that:

As the complexity of the operation increases, the need for greater coordination seems to become crucial to the overall successful operation of the district. The 
temptation to become more centralized and uniform, especially in policies and procedures, seems to also increase with increasing size and complexity (p.166). Richard Meeth (1971) concurred. He indicated that in larger systems with central administration, faculty and administrators lose some of their autonomy and feeling of responsibility for, and interest, in programs on their own campuses.

Multi-campus systems... can of course provide many benefits which an individual college or campus cannot possibly afford, but the dangers are ever present that... responsibility and control shift from the member institutions to the central administration $(\mathrm{p} .44)$.

Henry and Creswell (1983) expanded the research on the delineation of district and campus decision-making functions by analyzing the relationship between certain factors such as size, number of district-level personnel, number of campuses, administrative salaries, etc., and the levels at which decisions are made. One important finding of this study suggested that the level at which decisions are made vary by the number of the campuses in the system. As the number of campuses increased there was a gradual decentralization of decision-making (p.126). This appears to be consistent with Jones' study but in conflict with Buckner's and Meeth's conclusions. Kintzer's 1984 monograph showed a relationship between the maturation of a multi-unit 
system and decentralization which was, in fact, a validation of Jensen's early study in which he observed "The older the district was in years of operation, the more independence and freedom each of its campuses had" (p.162).

A large multi-unit district, like any large corporation, can experience dysfunctional behavior if there is ambiguity regarding the placement of the central office and campus functions. Some of the major criticisms of multi-unit community college systems cited by Kintzer, Jensen and Hansen (1969) are that adversarial relationships between individual colleges and the district office develop due in part to the divergent perceptions of the role each should play in district operations. These researchers found that in general, district personnel tend to be insensitive to certain program needs and may become too directive.

Richman and Farmer saw the trend toward centralization in higher education as "excessive, unwarranted, unwise, and dysfunctional to the goals, priorities, and viability of the institution" (p.247). This viewpoint, a reaffirmation of the contingency model, criticized an across-the-board standardization philosophy in favor of shared authority to maximize strengths and minimize weaknesses.

In a study conducted in 1972 by Jenkins and Rossmeier a surprising number of staff members at urban multi-unit community college districts reported a low level of trust of administrators and trustees. Their study concluded, however, that although a moderate degree of decentralization of 
authority over most activities was found to be advantageous to unit administrators, it was equally important that authority over activities which have broad impact throughout the system be retained at the district level.

Morrissey, in a 1967 article, presented his view that multi-unit community college districts should be decentralized in administrative structure.

I recommend that in complex community college systems each college established be called a college, with the privilege of naming the school reserved for the college professionals and interested citizens of the region to be served. The word "campus" calls forth the mummified ghost of higher educational mistakes; the word "college" describes what the institution is in fact $(p .40)$

Such a simple solution to a complex problem does not change the basic assumptions of a multi-unit organization. The work done in 1972 by Richardson, Blocker and Bender illustrates this concept as the authors comment about centralization in multi-unit urban districts:

Even in districts that have sought to provide maximum autonomy to campus units by calling them colleges and by providing the chief executive with the title of president, there is still a constant tension accompanied by the ever-present realization that the needs and priorities of the system take priority over the aspirations of the individual units (p.125). 
Studies conducted by Jensen (1965), Kintzer, Jensen and Hansen (1969), Jenkins and Rossmeier (1974), Buckner (1975), and Chang (1978), and Henry and Creswell (1983) on multi-unit districts indicated that in general, management functions, including business activities, data processing, personnel, warehousing, facilities planning and food services, were usually handled at the district level, while program and service functions including curriculum, student personnel services, library services, occupational programs, counseling and testing were college-based. There were of course, variations. Interestingly enough, certain functions related to instruction and student services that were centralized in the 1970's appear to have moved to the college in the $1980^{\prime} \mathrm{s}$ as reported by kintzer in 1984. The study . . verified the continuing trend toward decentralization of responsibility/authority, moving from two-year college district/central office to individual colleges. The direction while strongest at the coordination functional level, appeared consistently in other functions from policy formation through the processes of decision-making (p.24). The advantages and disadvantages of centralized systems are best summarized in studies conducted by Wynn (1973) and Chang (1978).

Wynn reviewed the placement of management authority and responsibility as perceived by campus chief executives while Chang focused on the positive and negative aspects of 
centralized versus decentralized systems.

From the district view, according to Wynn, decentralization lessens efficiency and accountability, increases ambiguity of roles, and creates uncertainty about goals. In addition, Wynn suggested that organizational change is far more difficult in a decentralized system because the locus of control is diluted. "Only the expenditure of great power causes rapid change" (p.44).

Chang's conclusion that the most effectively organized district would be one which lies somewhere between a decentralized and centralized system, was supported by his findings regarding the advantages of each of these organizational patterns.

Centralization. According to Chang, a centralized system will:

1. Facilitate a more direct communication process to one key administrator as opposed to several separate administrators. The central administrator can maintain a single focus, responsibility and authority; therefore, institutional objectives can often be more clearly delegated, defined and directed.

2. Discourage an over-emphasis on individual campus prestige by emphasizing maximum educational services districtwide.

3. Facilitate resource sharing and exchange of ideas $(\mathrm{p} \cdot 34)$ 
Decentralization. The positive aspects of a decentralized system, according to Chang are that such a system will:

1. Fix responsibility at a lower structural level thus minimizing confusion about roles and responsibilities of college personnel.

2. Avoid deferring local decision to a higher administrative level.

3. Promote the development of leadership among campus administrators who must assume a greater degree of responsibility for their decisions.

4. Improve staff morale because of greater participation of decision-making (p.47).

Advocates of the multi-unit structure argue that a centralized system results in cost savings, equity and uniformity of purpose, while those opposed claim that centralization can lead to "external intrusion in essential academic matters properly the concern of individual campuses" (Mayhew, 1977, p.303). Unfortunately, there is no formula that will guarantee a perfect system. In a 1970 article, Block suggested that since the organizational patterns of multi-unit districts are so varied, it is difficult to choose a system that would fit each case. Block concluded, however, that despite the autonomy requested by the campuses, there are still areas that require a high degree of uniformity throughout the district. Within that uniformity, however, a participative model is possible, and 
according to Richardson, Blocker and Bender (1972) most desirable. They suggest that such a model may be even more important for multi-unit districts than for one-college systems.

It is clear that the locus of control in multi-unit districts is not dependent solely upon structural considerations. There is evidence that internal and external factors including politics, the administrative style of district and college leaders, legal constraints, policy decisions, and a host of other factors influence authority relationships within such districts.

The balance between centralization and campus autonomy. according to Kintzer (1984), depends in large measure on the administrative style of the chief executive officer, while Buckner, in a 1975 study, concludes that the degree of centralization is a result of factors such as community power structure, the personal leadership style of the chief executive officer of the district, and the stage of development of the district (p.166). $\underline{\text { Summary }}$

In summary, four important conclusions can be abstracted from the research dealing with the locus of control of decision-making functions. 1. Neither a highly centralized nor decentralized distribution of authority is the best approach to organizational effectiveness. 
2. There is a great increase in effectiveness if participation in decision-making is simultaneously increased for staff members at all hierarchical levels. 3. Factors such as size, organizational complexity, institutional maturity, leadership style, politics, and legal constraints can influence the location and extent of the decision-making authority within an institution. 4. There must be an understanding of the organization and congruent perceptions among its leaders of how their roles in the decision-making process contribute to organizational goals.

The more effective institutions tended to be those in which various members as well as each administrative unit had a clear understanding of the authority and responsibilities of the other (Kintzer, 1984, p.9).

\section{Leadership Roles}

Role Delineation

Role ambiguity is indigenous to college presidents in a multi-college district. While the presidents are, on the one hand, considered the educational leaders of their separately accredited colleges, they can, on the other hand, merely be expeditors of district decisions.

Richman and Farmer (1977) identified a president's job as "defining, redefining, supporting, and implementing the goals, priorities, and changing programs of the institution" (p.239). In a multi-college district, the term 
"institution" may in fact be defined and viewed differently by the presidents and chancellor. As a result the role the presidents play in the decision-making process may be ambiguous and not clearly understood by either party.

A monograph by Whiting (1980) described the restrictive atmosphere in which college leadership is expected to function.

Dilemma arises from a condition in which leadership is expected and imperative, but is attenuated and occasionally abrogated by the central administration - - There is a kind of psychological debilitation of campus executives. For example, in systems where an appointment of major administrative officers below the level of chancellor or president must be sent to the central administration and governing board for final approval, the potential veto of the campus executive's selection creates an attitude of resentment (pp.26-27). In a multi-college district can leadership roles be effectively delineated to minimize conflict? Although there has been little research in this area at the community college level, there are some studies that attempt to deal with role delineation.

Buckner (1975) found that in urban multi-college districts the chief executive officer's role is generally well understood by constituents. He or she is involved more with external matters than with the day to day operation of the colleges. Areas include board and community 
relations and overall district planning. Daily operations are delegated to others including the college presidents. Buckner further noted that those closest to the chief executive officer of the district were most accurate in their perceptions of his or her role. Morrissey in 1967, indicated that the chief executive officer is too far removed from any of the individual campus to make any controlling decisions.

Most systems do not pretend - in their own retreats that the nominal head of a multi-unit college system actually makes the controlling decisions affecting the operations of the specific schools (p.39). An earlier study by Shannon (1962) focused on the role of community college presidents. He asked the presidents on what areas they spend most time and what areas were the most neglected. He found presidents spend most time on matters relating to (1) staff, (2) public relations, (3) finances, and (4) students. Those areas most neglected were (1) alumni, (2) legislation, (3) students, and (4) professional activities. Two major conclusions from that study were:

1. Presidents believe their colleges should be autonomous units.

2. Presidents see their roles as educational leaders and as formulators of policy.

An article by Cohen and Roueche (1969) described a study in which they attempted to determine if community college presidents (primarily in single college districts) 
were in fact assigned educational leadership responsibilities by their boards of trustees, and if the presidents actually gave their attention to this area. After Cohen and Roueche reviewed presidents' job descriptions, board minutes, and college policy manuals, they concluded that, "In general, the (community) college president is neither assigned responsibility nor held accountable for educational leadership" (p.18). The primary duties of the presidents in those districts were, (1) campus development, (2) implementation of board policies, (3) fiscal management, (4) supervision of administrative staff faculty, and (5) supervision of safety on the campus.

A perusal of position descriptions for the presidents within California multi-college district (1986) indicated that the majority of these documents identified educational leadership as a responsibility of college presidents. It may be inferred that because most presidents within these college districts have fewer responsibilities in overall district management than their colleagues in single college districts, there is an expectation by the governing board and chancellor that the presidents will take on more of an educational leadership role at their campuses. Perhaps the best summary of the relationship between the district chancellor/superintendent and the college presidents in multi-college districts can be found in Jensen's 1984 update to his earlier study in which he quotes 
Dr. William J. Moore, former superintendent of South Orange Community College District:

- . the key points are specialization of function and delegation of responsibility in district and college administrative functions. By this I mean that it is fundamentally necessary to distinguish between the functions, i.e., roles, of superintendent and president so that the superintendent does not feel the need to do many of the same jobs as the presidents do and vice versa - . Naturally the president needs to consult with the superintendent and keep him informed... and in the final analysis, live with the superintendent's wishes - . But (certain) jobs are necessarily the primary responsibility of the president. If not, then there is no substantive, functional distinction between the superintendent and president. Moreover, if the superintendent does not permit such a delineation of functions he cannot do well the things that only he is in a position to do and at the same time forces the president into the untenable role of being nothing more than an administrator and expediter of district decisions. What is needed is a separation of function which gives the superintendent an opportunity to be a leader and developer at the board and statewide levels while permitting the president to be a leader and developer at the campus level. Both, of course, have plenty of routine, administrative chores. But both must have "territories" within which they have responsibility which is not constantly intruded upon by the other (pp. 35,36$)$.

Building Relationships

A major aspect of the ambiguity of college presidents' decision-making roles can be traced to the chancellors' and presidents' perceptions of the presidents' decision-making involvement within multi-college districts. In 1972 Van Trease looked at the relationship between district CEOs and chief campus administrators. Van Trease asked both groups to respond as to how they perceived district participation in nine functional areas. In only two areas was there concurrence between district and campus administrators. 
Although it is not an easy task to build a relationship between chancellor and presidents that will guarantee congruence of perceptions regarding their decision-making roles, such a relationship is key to goal attainment in a multi-college district. George Odiorne (1965), in defining management by objectives, identified the need for a cooperative understanding among the organizational leadership.

The superior and the subordinate managers of an enterprise . . (must) . . jointly identify its common goals, define each individual's major areas of responsibility in terms of the results expected of him, and use these measures as guides for operating the unit and assessing the contribution of each of its members (p.111)

An organization's expectations are a manifestation of its system of values. Hersey and Blanchard (1977) view those expectations as most effective when organizational perceptions are shared:

To say that a person has shared expectations with another person means that each of the individuals involved perceives accurately and accepts his or her own role and the role of the others (p.135). The size of an organizational system, however, can affect leadership behavior and as a result impact on these shared expectations. Yukl (1981), Blankenship and Miles (1968) and others found that as the leaders' span of control increases 
in a large organization they rely more heavily on those they delegate to initiate action, but have less time to spend with them to engage in interpersonal behavior necessary to maintain effective relationships. In addition, the interdependence between or among the colleges in a multi-college district affects leadership behavior. Such interdependence, according to sayles (1979) represents a threat to each of the colleges within the district since the actions of leaders within each college might require modification to accommodate the needs of others within the organization. Just as community college chancellors experience discomfort when their governing board intrudes on their districtwide management system, so do presidents in multi-college districts resent the intrusion of the chancellor or others at the district level into what they consider to be their decision-making domain.

Peters and Waterman (1982) suggest that each professional needs to feel a sense of purpose in what he or she is doing within the organization, and Rosabeth Moss Kanter (1983) states that "actual involvement in a decision-making process... tends to teach people to articulate corporate goals" (p.259).

organizational culture expert Edgar schein cautioned in 1985 that the process of leadership cannot be separated from the process of building organizational culture; those basic indisputable underpinnings of the organization that direct its system of values. Leadership as distinguished 
from management is the "creation of management of culture" (p.171). Schein's "culture" (1985), Argyris' "Theories in Use" (1976), and McGregor's "Theories X and $Y "$ (1960) all identify those implicit assumptions that guide behavior in an organization.

This aspect of the literature review is foundational to the premise of this study. The chancellors' and presidents' sense of purpose; their cooperative involvement in the decision-making process; their interdependent relationship and the transformation of shared values into an organizational culture; all will act as a unifying force to move the leadership of the district toward a common mission to create a more effective organization. 


\section{Chapter III \\ RESEARCH DESIGN AND METHODOLOGY}

Design of the study

The objective of this analytical study was to determine in which functional categories and on what items within those categories there were congruities and discrepancies between the chancellors' and presidents' perceptions of the presidents' decision-making role in multi-college districts. In addition, the study was to identify, through the use of descriptive data, those factors that might help to interpret those congruities or discrepancies.

A nonexperimental design was determined to be appropriate for achieving the objective. Survey research methodology provided the basis for the design of the study. This method was chosen as the most suitable to elicit and compare perceptions of chancellors and presidents. Districts that were selected met the criteria for a multi-college organizational structure.

A 24 item Likert-type scale was developed for the study. This scale was similar to the one developed by Tyne (1984) who compared superintendents' and secondary principals' perceptions of the role of the principal. 
The study was designed to provide foundational data for the development of new research questions dealing with the relationship between the differences or congruities in perceptions and certain external factors. The resultant research questions will be of value for future studies of multi-college districts.

\section{Selection of Sites for Data Collection}

California multi-college districts were chosen as typical of multi-college organizational structures. California does not have a state-controlled community college system, and 18 of its 70 districts are organized as multi-college districts.

Because such districts are complex organizationally, with a district governance structure intervening between the colleges and board of trustees, decision-making must be shared by the college presidents and district chancellor. The study limited itself to California multi-college districts that had no more than three colleges in each district. In addition, the literature has identified urban districts as being unique in their local governance structure and, therefore, they were not part of the study. As a result 14 districts and 34 colleges were contacted for inclusion in the study. They were: 


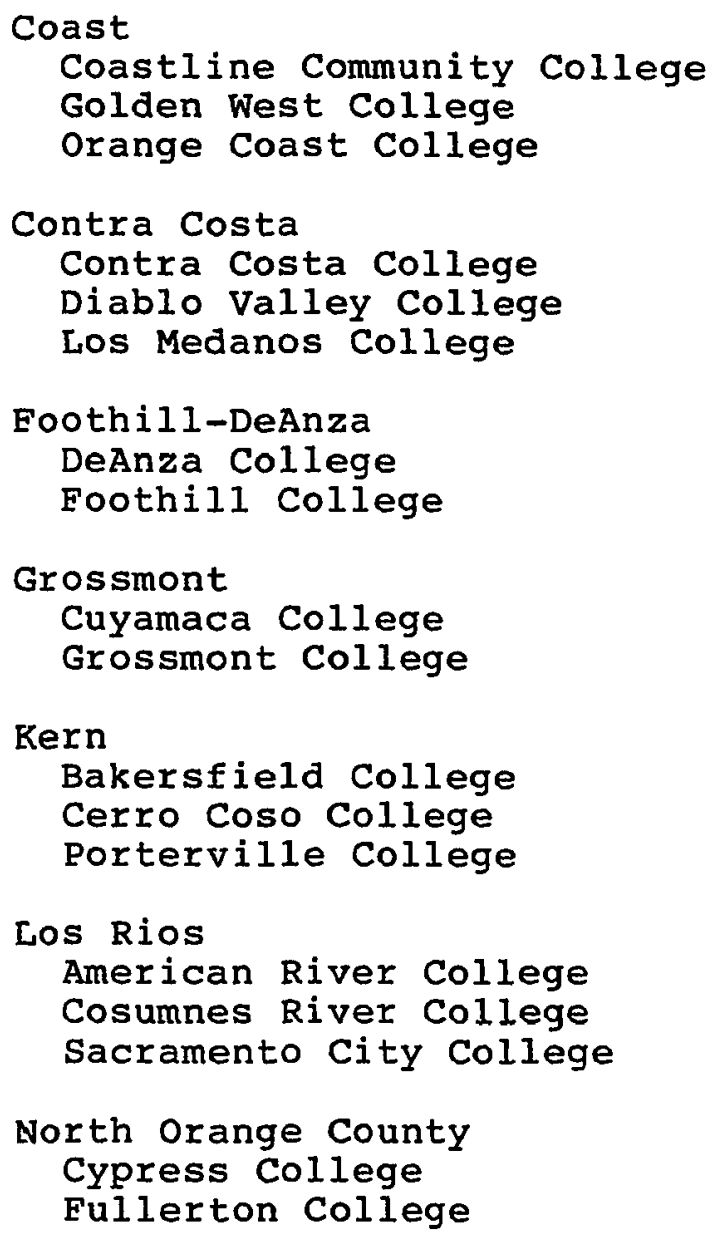

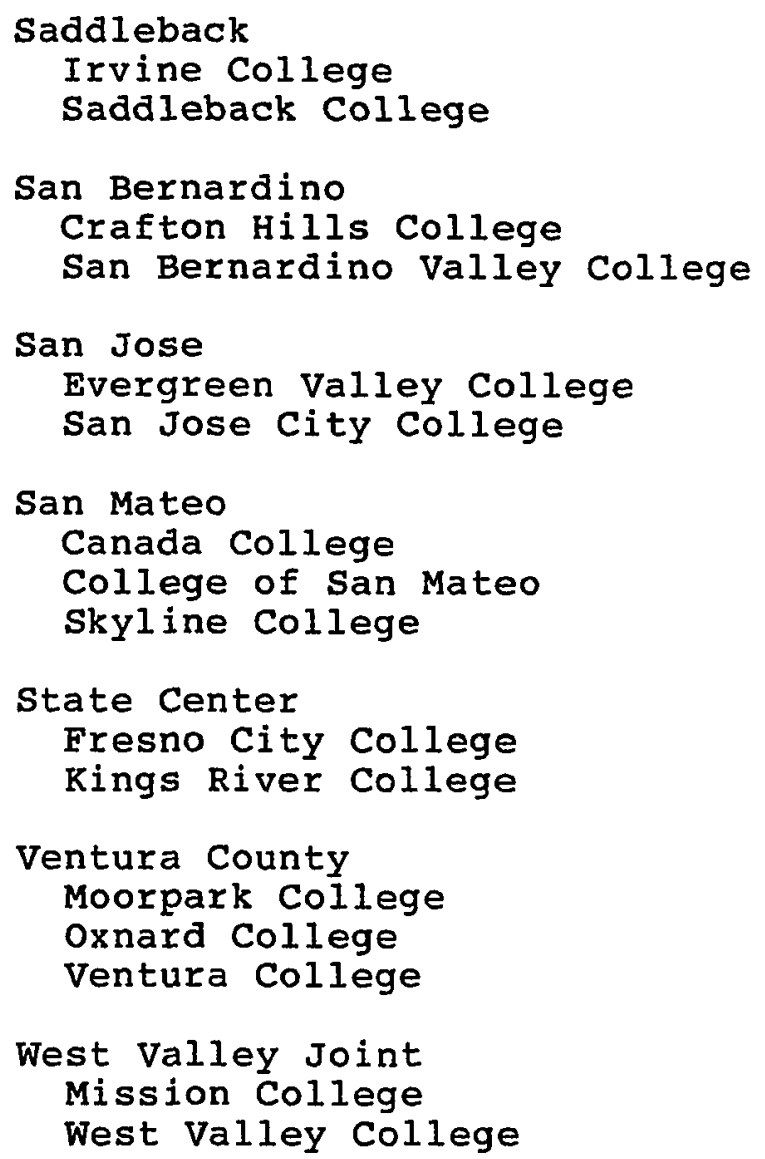

Los Angeles, Peralta, Yosemite and San Diego were excluded from the study. The Los Angeles Community College District with nine colleges is atypical. Peralta is currently undergoing a major reorganization of its five college system with an expectation that two of the colleges will be absorbed within the Peralta District or another neighboring district by late 1986. Although the Yosemite District has two colleges, the superintendent serves as both the chief executive officer of the district and the president of one of the colleges. This organization is not 
typical of multi-college structures. Finally, San Diego Community College District was eliminated from the study since the district chancellor and college presidents took part in the validation of the survey instruments.

\section{Selection of Subject Population}

All chancellors and presidents within California multi-college districts were contacted, with the exception of those noted previously. The population included 14 chancellors and 34 presidents.

Each president and chancellor was asked to complete the Role Perception Questionnaire and to respond to the Professional Background Questionnaire.

The criteria for selection of the colleges for this study were:

1. The community colleges must be located in California to ensure like governance patterns.

2. Each district must have a separate chief executive officer appointed by the Board of Trustees.

3. Each college must be separately accredited.

4. Each college must be headed by a president.

Instrumentation

The researcher constructed three instruments. The first was the Role Perception Questionnaire used to record the perceptions of the presidents and chancellors relative to the decision-making involvement of the presidents at the 
college and district levels.

The Role Perception Questionnaire required the

participants to rank order the extent of decision-making

involvement the college president has in a variety of

functional areas.

The second instrument designed for use in this study

was the Professional Background Questionnaire which

requested data on the professional experience of each respondent.

The final element was a District Profile sheet prepared for each of the multi-college districts responding.

The Professional Background Questionnaire and District Profile sheet enabled the researcher to analyze a variety of external factors to determine if they appeared to have a relationship to the responses by presidents and chancellors to the Role Perception Questionnaire.

\section{Role Perception Questionnaire}

An analysis was made of the presidents' decision-making responsibilities as indicated on their official position descriptions and in the literature. Those duties common to all thirty-four presidents were extracted and placed into appropriate groupings or "functional categories." These categories were developed after reviewing the work of La Vire (1961), Graham (1965), Buckner (1975) and Kintzer (1984). All had analyzed administrative functions found in community colleges and placed them into general groupings. 
For purposes of this study the categories defined by Buckner were the most appropriate. The title of one category, legitimization of institution policies and decisions, was simplified for purpose of clarity. The general categories used in this study were: planning, finance, communication of policies and decisions, external relations, educational leadership and evaluation. These areas are consistent with the general functions contained in the 34 presidents' position descriptions. An explanation describing each of the general categories was included on the questionnaire.

There were six functional categories with four items contained under each. They were:

1. Planning:

a. Future or long-range planning activities.

b. Activities related to program expansion, addition, reduction, and contraction.

c. Planning of physical facilities for the present and immediate future.

d. Setting operational priorities.

2. Finance:

a. Activities concerning budget preparation.

b. Activities related to matching budget to program.

c. Activities concerning budget administration.

d. Activities related to the priority ranking of resource allocation levels. 
3. Communication of Rolicies and Decisions:

a. Activities pertaining to the maintenance of openness in the decision-making process.

b. Activities concerning cooperative participation in governance.

c. Activities concerning improving human relations or general morale.

d. Activities concerned with the improvement of communication networks.

4. External Relations:

a. Activities concerning accrediting agencies.

b. Activities involving state agencies, leaders and specific office holders.

c. Activities concerning groups, leaders, events within the local community or district.

d. Activities with various professional associations or other educational leaders in the state or nation.

5. Educational Leadership:

a. Presenting policy recommendations and alternative strategies to the Board of Trustees.

b. Activities concerning the initiation of educational policy and innovations in programs, operations, and management techniques. 
c. Activities involving administration, faculty, and staff; providing motivational leadership and support on their behalf.

d. Activities with student groups, councils, and individuals of the student body.

6. Evaluation:

a. Activities regarding decisions or evaluative judgments on the progress of the organization.

b. Activities concerning evaluative judgments on the efficiency of organizational operations.

c. Activities relating to judgments on personnel matters.

d. Activities concerning the assessment of perceived or real problems within the organization.

Presidents and chancellors in multi-college districts were asked to rate the level of decision-making involvement of the college presidents for each of the items, on a Likert-type scale from 1-5, from (1) no involvement to (5) total involvement. Gorden, writing in 1977 indicated: The value of the likert method is mainly in its use of the respondents themselves as the basis of item selection and in the use of the intensity-scaled response to each item. The former makes the scale more valid for the ultimate respondents, and the latter makes it possible to have a wider range of scores with fewer items (p.39). 
Validity

A pilot study was conducted to validate the items on the Role Perception Questionnaire. Both the items and categories were reviewed by six presidents of multi-college districts in the San Diego and Los Angeles areas who, after making some minor changes, verified that the items were directly related to the official position descriptions of presidents in multi-college districts. These items had been previously validated within their functional categories by 77 respondents in Buckner's 1975 study.

\section{Reliability}

Reliability was confirmed using a test-retest procedure. Twelve pilot subjects, including the presidents in the validity study who were asked to complete the questionnaire, responded again one month later. Rankings on the both the test and retest followed similar patterns.

\section{Professional Background Questionnaire}

Research had shown a relationship between the development of technical, human relations and conceptual skills and managerial effectiveness (Mann, 1965). The relative importance of these skills varied from one situation to another, and such skills were not the only factors contributing to one's ability to exercise leadership. There was, however, evidence that individuals identified as having an appropriate combination of skills and prior experience based upon the requirements for a given 
managerial position, had a high potential to succeed. The accuracy of prediction labout likely success in higher management positions) is increased when the skills, traits and knowledge especially relevant for a position are determined in advance (Yukl, 1981, p.89). The identification of possible connections between the professional background of the chancellors and presidents and their perceptions about the presidents' decision-making involvement was thought to yield valuable insights into the managerial strengths of the respondents. In addition, there was some evidence that indicated knowledge of the district or previous experience in multi-unit organizations might contribute to a better understanding of decision-making functions within the district (Kintzer 1984).

The Professional Background Questionnaire was designed to obtain a comprehensive profile of the professional background experience of the presidents and chancellors. A study by Shannon in 1962 looked at community college presidents' perceptions of their roles. As part of this study, educational and professional background information was obtained about each of those presidents. Although generalizations were made, there was little attempt to draw any relationships between perceptions of the presidents' roles and background. The questions posed on the Professional Background Questionnaire were similar in scope to Shannon's, but were utilized in this study to investigate possible relationships. 
District Profile sheet

Jensen (1965), Graham (1965), Buckner (1975) and Henry and Creswell (1983) were among those who found a connection between the location of decision-making functions in multi-unit community college districts and certain characteristics of those districts. The elements included size, history, location of the district and the administrative structures and reporting relationships within the systems. By gathering this information, it was possible to determine if connections could be made between district characteristics and decision-making role perceptions. Profile data was collected from the multi-college districts responding to the survey, from the California Community Colleges' State Chancellor's office, and from the Association of California Community Colleges Administrators.

\section{Data Collection}

\section{Confidentiality}

Following dissertation committee approval of the proposal, provisions to ensure confidentiality of the subjects were approved by the University of San Diego Human Subjects Committee. Subjects were assured that their responses would be anonymous. For purposes of the research design it was necessary to identify each district and the colleges within that district through coding. However, information specifically identifying the district, college, president and chancellor did not appear in the study. Since 
the researcher was employed in a multi-college district (not included in the study), it was determined that subjects might view the survey as something other than a general research project. Therefore, subjects received the survey instruments from University of San Diego and returned them to the same address. Respondents wishing to obtain the results of the study returned a postcard which was included with the questionnaire but mailed back to the university separately.

\section{Data Collection Procedures}

The Role Perception Questionnaire and Professional Background Questionnaire were mailed to the 14 chancellors and 34 presidents in California multi-college districts. A letter was included from a retired California community college president urging a response, and directions were included by the researcher explaining the purpose of the study and of the procedures to be followed. Each respondent was provided with a return postage paid envelope.

Additional questionnaires and a letter from the researcher were sent to those who did not respond within a two week period. A telephone follow-up to the secretaries of non-respondents was made 10 days later.

Eleven chancellors and 28 presidents responded to the survey. This sample represented $79 \%$ of the chancellors and 82\% of the presidents contacted. One chancellor's response was unopened, when the researcher learned that an assistant to the chancellor had responded to the questionnaire. 
The District Profile Sheet was completed for each of the 11 responding districts where both the chancellor and at least one president had responded. Information regarding salaries of presidents and district administrative personnel was available to the researcher from only 8 of the 11 districts. The most recent organization chart for each of 10 districts was obtained, however, one district indicated it was in the process of revising its chart and could send nothing. The information about that district was obtained by telephone from the chancellor's office of the district.

Hypotheses

Four hypotheses were developed from the research questions, and were formulated as follows:

1. There will be no differences statewide between the district chancellors' and college presidents' perceptions of the presidents' overall decision-making involvement at the college level and districtwide.

2. There will be no differences statewide between the chancellors' and college presidents' perceptions of the presidents' decision-making involvement by functional categories at the college level and districtwide.

3. The observations of the chancellors and presidents statewide concerning the presidents' decision-making involvement on each item on the Role Perception Questionnaire will not differ at the college level or districtwide. 
4. The observations of the chancellor and the presidents in each district concerning the presidents' decision-making involvement on each item on the Role Perception Questionnaire will not differ at the college level or districtwide.

\section{Data Analysis}

\section{Procedures: Hypotheses 1, 2, 3}

The quantitative data on the Role Perception Questionnaire was analyzed using the statistical Package for the Social Sciences (SPSS). Tuckman (1978), among others, has identified its appropriateness for use in educational research. Because of the small population, however, it is recommended that similar analyses be conducted in the future using larger samples.

The t-test was applied to the first two hypotheses that there would be no differences statewide between the district chancellors' and college presidents' decision-making involvement at the college level and districtwide, overall, and by functional categories.

The third hypothesis stated that the observations of the chancellors and presidents statewide concerning the presidents' decision-making involvement on each item in the Role Perception Questionnaire would not differ at the college level or districtwide. To test this hypothesis a $\left(\underline{x^{2}}\right)$ test was applied to summarize relationships in cross tabulation tables. 
Due to the nature of the study, and the intent of the researcher to provide foundational data for the development of research questions and directional hypotheses, significance was tested at a liberal .20 level. This level is supported by Hinkle, Wiersma and Jurs (1979).

In (certain) settings, indicators of direction or a trend might be important and would be evidenced by a less substantial departure from the null hypothesis. In these cases, a less conservative level of significance $(.10$ or .20) might be used (p.150).

Procedures: Hypothesis 4

Background. Hypothesis 4 indicated that the perceptions of the chancellor and the presidents in each district concerning the presidents' decision-making involvement on each item on the Role Perception Questionnaire would not differ at the college level or districtwide.

Prior to establishing analytical procedures for this hypothesis, it was necessary to review the meaning of the question posed by the first three hypotheses in relation to that posed by the fourth.

By testing the first three hypotheses, perceptual congruities and differences between the chancellors and president statewide were investigated.

The fourth hypothesis, posited a different relationship. The chancellor of each district is, by law, given the authority by the district's board of trustees, to 
implement the board's policies by managing all operational aspects of the district (Jensen, 1965). It is the chancellor then, who determines what level of involvement the presidents of that district will have in the decision-making process. The power to make this determination elevates the "chancellor's perceptions" to "district assumptions" about what the presidents' decision-making involvement is to be in the district.

Analysis. Given this relationship, district assumptions (as identified by the chancellor) about each item on the Role Perception Questionnaire were compared to the mean of the presidents' responses to each item.

An interval scale is assumed on the 5-point Likert-type instrument. Points on the scale ranged from (1) "no involvement" to (5) "total involvement." Therefore, a 1.5 deviation between responses on the scale would represent a $30 \%$ difference in perceptions. The researcher defined these discrepancies as significant enough to merit further investigation. In addition, if two of the four items within any functional category showed discrepancies in a given district, the researcher identified those categories as "operationally significant" for that district.

In these instances, arithmetical procedures were preferable over statistical ones so that patterns, which would not have been apparent in a "statistically significant" sense, could be analyzed. 
The following conditions applied in the analysis of hypothesis $4:$

1. Only those districts in which a chancellor and at least one president responded were included.

2. If there was a deviation of 1.5 on the 5-point Likert-type scale between the response by the district chancellor and the mean of the presidents' response to each item, it was operationally identified as a discrepancy.

3. If two of the four items within a category showed discrepancies, that category was considered to be operationally significant.

4. If there was a wide disparity between individual presidents' responses, thus producing a misleading mean, it was noted in the analysis.

5. If a chancellor and only one president of a given district responded, that president's rankings on each of the items were used in the comparisons against the district assumptions.

Anecdotal Information and Literature Review Anecdotal information obtained from the presidents and chancellors, individual district demographics and findings from other related studies, were reviewed with the quantitative data analysis to enable the researcher to develop a base of knowledge for the development of research questions leading to further study of specific areas. 


\section{Chapter IV \\ ANALYSIS OF THE DATA}

\section{Introduction}

For purposes of clarity, the analysis of the data on the Role Perception Questionnaire was separated in this chapter from the anecdotal information contained in the Professional Background Questionnaire and District Profile Sheet. This anecdotal information identified factors relating to the chancellors, presidents and districts, and was designed to assist in the interpretation of the results of the statistical findings.

Eleven chancellors and 28 presidents completed the questionnaires. This sample represented $79 \%$ of the chancellors and $82 \%$ of the presidents of the 14 districts surveyed. All responses provided useable data. Information on the District Profile Sheet was obtained from each of the 11 districts in which a chancellor and at least one president responded.

\section{Role Perception Questionnaire}

The statistical analysis of the Role Perception Questionnaire was divided into four sections in response to each of the hypotheses posed by the research questions. The 
level of significance, as discussed in Chapter Three, was at the $(\underline{a}=.20)$ level since the results are designed to provide direction for more definitive research in the area. Hypotheses $1,2,3$, and Findings

Hypothesis: 1. There will be no differences statewide between the district chancellors' and college presidents' perceptions of the presidents' overall decision-making involvement at the college level and districtwide.

A t-test comparison of chancellors' and presidents' responses statewide is shown in Table 1. Although there was no significant difference at the $(\underline{\alpha}=.20)$ level between those two groups in their responses to the presidents' decision-making involvement at the college level, there was a difference districtwide. Hypothesis one was tenable for the college level but not for the district level. Table 1 Chancellors and Presidents Perceptions Statewide

\begin{tabular}{ccccc}
\hline Category & $\begin{array}{c}\text { Number } \\
\text { of Cases }\end{array}$ & Mean & value & $\begin{array}{c}\text { 2-Tail } \\
\text { Prob. }\end{array}$ \\
\hline $\begin{array}{c}\text { College } \\
\text { Chancellors } \\
\text { Presidents }\end{array}$ & 11 & 108.5455 & 0.09 & 0.929 \\
$\begin{array}{c}\text { District } \\
\text { Chancellors } \\
\text { Presidents }\end{array}$ & 11 & 108.1786 & & \\
& 28 & 74.1786 & 2.12 & $0.041 *$ \\
$* \underline{\alpha}=.20$ & & & &
\end{tabular}


Hypothesis: 2. There will be no differences statewide between the district chancellors' and college presidents' perceptions of the presidents' decision-making involvement by functional categories at the college level and districtwide.

The t-test showed significant differences at the $(\underline{\alpha}=.20)$ level statewide between chancellors' and presidents:' perceptions in the evaluation category at the college level. Districtwide differences were found in four of the six categories. These were planning, communication of policies and decisions, leadership and evaluation. It should be noted that both chancellors and presidents concurred that presidents have a great deal of decision-making involvement at the college level. Generally, however, at the districtwide level, chancellors perceived that presidents had greater decision-making involvement than the presidents perceived they had. Table 2 illustrates these findings. Hypothesis 2 was tenable for the categories of planning, finance, communication of policy and decisions, external relationships and leadership at the college level. It was rejected in the category of evaluation at that level. Hypothesis 2 was tenable for the categories of finance and external relationships at the district level. It was rejected in all other categories at that level. 
Table 2

Chancellors'and Presidents' Perceptions

statewide by Category

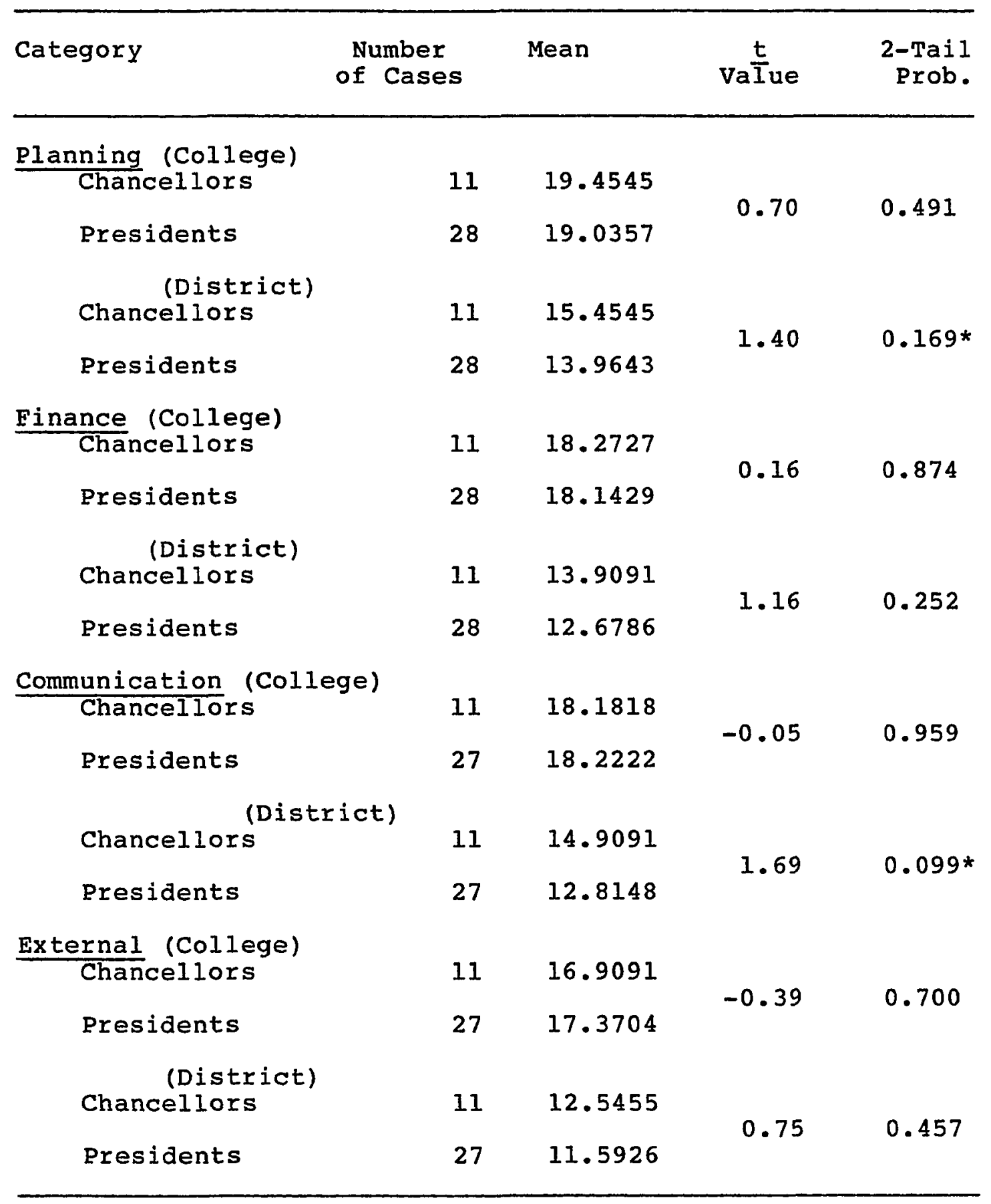


Table 2 (continued)

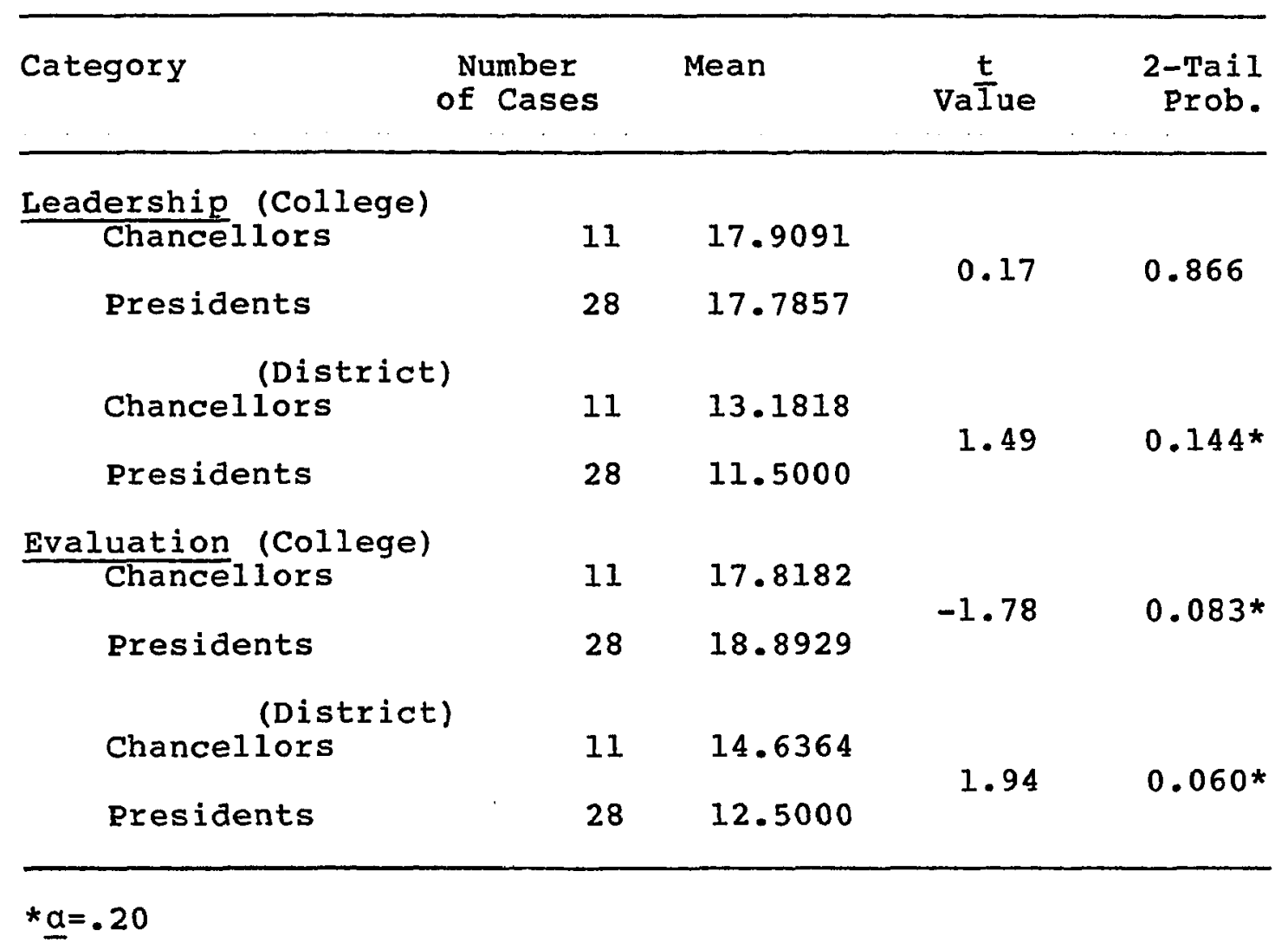

Hypothesis: 3. The observations of the chancellors and presidents statewide concerning the presidents' decision-making involvement on each item in the Role Perception Questionnaire will not differ at the college level or districtwide.

Hypothesis 3 was found to be tenable for $83 \%$ of the items pertaining to the presidents' decision-making involvement at the college, and only $67 \%$ of the items pertaining to the presidents' decision-making involvement districtwide. 
The following items were the exception:

1. Activities relating to matching budget to program (college and districtwide).

2. Activities pertaining to the maintenance of openness in the decision-making process (districtwide).

3. Activities pertaining to cooperative participation in governance (districtwide).

4. Activities involving state agencies, leaders and specific office holders (districtwide).

5. Presenting policy recommendations and alternative strategies to the Board of Trustees (districtwide).

6. Activities involving administration, faculty, and staff; providing motivational leadership and support on their behalf (districtwide).

7. Activities with student groups, councils, and individuals of the student body (college and districtwide).

8. Activities concerning evaluative judgments on the efficiency of organizational operations (college and districtwide) .

9. Activities concerning the assessment of perceived or real problems within the organization (college).

Table 3 summarizes the findings in response to the third hypothesis. The items showing significance $(\underline{\alpha}=.20)$ are indicated. 
Table 3

$\chi^{2}$ significance statewide by Item

$\begin{array}{lccc} & \text { Questionnaire Items } \\ \text { a } & \text { b } & \text { d }\end{array}$

1. Planning

$\begin{array}{lrrrr}\text { College level } & .6624 & .8212 & .5802 & .4947 \\ \text { Districtwide } & .7135 & .7219 & .5031 & .5918\end{array}$

2. Finance

$\begin{array}{lllll}\text { College level } & .5576 & .4955 & .0300 * & .6591 \\ \text { Districtwide } & .5528 & .2461 & .1605 * & .7675\end{array}$

3. Communication

$\begin{array}{lcccc}\text { College level } & .7783 & .2628 & .7670 & .7321 \\ \text { Districtwide } & .1297 * & .1938 * & .6201 & .7517\end{array}$

4. External

$\begin{array}{lllll}\text { College level } & .9780 & .5280 & .4529 & .3024 \\ \text { Districtwide } & .8510 & .1268^{*} & .3473 & .7788\end{array}$

5. Leadership

$\begin{array}{lllll}\text { College level } & .2004 & .2573 & .6591 & .0723 * \\ \text { Districtwide } & .0039 * & .2106 & .1711 * & .0916 *\end{array}$

6. Evaluation

\begin{tabular}{lllll} 
College level & .4355 & $.1197 *$ & .3204 & $.0220 *$ \\
Districtwide & .3967 & $.0238 *$ & .6181 & .2837 \\
\hline
\end{tabular}

$\star \underline{\alpha}=.20$ 


\section{Additional Analysis of Statewide Data}

An additional analysis of the differences by item between chancellors and presidents yielded the following findings: Chancellors and presidents were in general agreement about the presidents' decision-making involvement at the college level. For the most part, both chancellors and presidents rated the presidents' involvement in all areas from "a great deal of involvement" to "total involvement." Minor perceptual differences at the college level of decision-making did occur, however, on a few items. Budget administration showed one such discrepancy, where 91\% of the chancellors believed the presidents have very strong decision-making involvement in budget administration at the college level as compared with $75 \%$ of the presidents who believed they play a very strong role.

Another difference emerged when the percentages of like responses were viewed in the general area of external relations. More than $80 \%$ of the presidents surveyed felt they had a very high level of decision-making at the college level in activities involving state agencies, leaders and specific office holders. Only $63 \%$ of the chancellors agreed with the presidents' assessment.

The perceptions of the chancellors and presidents differed to a greater extent on items relating to the presidents' decision-making involvement districtwide.

On the items dealing with the planning of physical facilities for the present and immediate future, and 
activities concerning budget preparation, only $42 \%$ of the presidents viewed themselves as having a very strong decision-making role districtwide as compared with $72 \%$ of the chancellors. Widely divergent views were held by chancellors and presidents concerning evaluative judgments on the efficiency of organizational operations. Seventythree percent of the chancellors viewed the presidents as playing a strong decision-making role districtwide compared to only $28 \%$ of the presidents with the same opinion.

Based upon the responses to each item on the Role Perception Questionnaire, with few exceptions, chancellors statewide appeared to believe their presidents have greater decision-making involvement districtwide than the presidents perceived they have. On the other hand, chancellors and presidents were in general agreement on the presidents' decision-making involvement at the college level. Hypothesis 4 and Findings

Hypothesis: 4. The observations of the chancellor and the presidents in each district concerning the presidents' decision-making involvement on each item in the Role Perception Questionnaire will not differ at the college level or districtwide.

As shown on Table 4, there was congruence on a majority of the items on on the Role Perception Questionnaire at both the college and districtwide levels. 
Table 4

Item Discrepancies by District

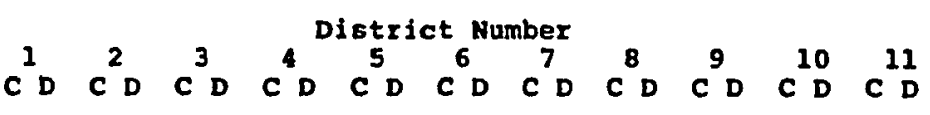

\section{Planning}
a. Long Range
b. Program
c. Facilities
a. Priorities

$\begin{array}{lll}\mathbf{D} & \mathbf{D} & \mathbf{D} \\ \mathbf{D} & & \mathbf{D} \\ \mathbf{D}\end{array}$

$\mathbf{D}$
$\mathbf{D}$
$\mathbf{D}$

D

\section{Finance}
a. Budget Prep.
b. Prog/Budg Match
c. Budget Admin.
d. Resource Alloc.
D

D $\begin{array}{ll}\mathbf{D} \\ \mathbf{D} \\ \mathbf{D}\end{array}$
D $\quad$ D
D
D C D
C D D

3. Communications
a. Openness
b. Governance
c. Human Relations
d. Networks
D C

C

$\begin{array}{lll}\text { D } & & \\ \text { D } & & \\ \text { D } & \text { C }\end{array}$

D

$\begin{array}{lll} & \text { D } & \\ \text { D } & \text { D } & \text { D }\end{array}$

4. External Relations
a. Accreditation
b. State
c. Communication
d. Prof. Assoc.

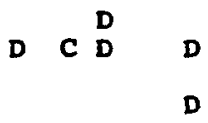

D C

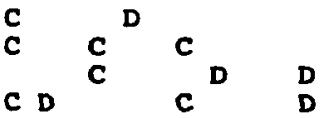

5. Leadership
a. Bd. of Trustees
b. Initiation
c. Motivation

d. Students

D

c

c c

D

$\begin{array}{lll}\text { C } & & \text { D } \\ \text { C } & \text { D } & \text { D } \\ & \text { D } & \text { D } \\ & & \text { C }\end{array}$

6. Evaluation

a. Progress

b. Org.Efficiency

c. Personnel

a. Problems

D

D

D

D

D

D

$\begin{array}{lll} & \text { D } \\ \text { D } & \text { D }\end{array}$

$C=$ college level discrepancy

D = districtwide discrepancy 
In analyzing the data supporting Hypothesis 4, the researcher identified as "operationally significant" functional categories with two or more item discrepancies (50\%), as areas of perceptual disagreement between the chancellor and presidents of a given district. This is consistent with the level established by kintzer (1984) in a similar analysis in which a comparative format was used to present the results of a study on centralized/decentralized responsibility in multi-unit community colleges.

College level decision-making involvement. Although there were few discrepancies concerning the presidents' decision-making involvement at the college level, one functional area is worth noting. One of the 11 districts showed discrepancies on three of the four items under the category of external relations, while two others showed discrepancies on two of the items in the same category (see Table 5). The item within that category in which a discrepancy appeared most frequently (36\% of the districts) was that concerning activities involving state agencies, leaders, and specific officeholders (item 4B). This may indicate some uncertainty about the chancellors' and presidents' roles in this area, since the chancellors have become more involved in political activities at all levels in recent years. The district showing three discrepancies at the college level in the external relations category. however, showed no other discrepancies at the college level in any other category on the Role Perception Questionnaire. 
Table 5

Multi-College Districts with Operationally significant Discrepancies in the "External Relations" Category at the College Level, and Years of Administrative Service

\begin{tabular}{llll}
\hline Years as & Years as & Chanc's years & Pres' years \\
Chanc/Pres & Chanc/Pres & as admin. in & with current \\
any M-C dist. & present dist. & present dist. & Chancellor
\end{tabular}

District 8

Chancellor

President 1

5
4

President 2

19

5

19

District 9

Chancellor

President 1

6

12

12

*District 10

Chancellor

President 1

President 2

4
12
1

4

12

12
1

22

5

4

5

5

10

4

*Also showed operationally significant discrepancies in the

finance and leadership categories at the college level. 
Three districts (27\%) showed differences on item 5d, which deals with activities with student groups, councils, and individuals of the student body. Interestingly, the assumption at each of these districts was that the presidents had "total decision-making involvement" on these items, while the presidents perceived only a "moderate level" of decision-making involvement.

one district indicated two discrepancies at the college level within each of two other categories; finance and leadership. However, no other district showed any college level discrepancy in the former area and there were few discrepancies from other districts in the latter category. This same district had seven items on which there were discrepancies at the college level. This represented $29 \%$ of all items on the Role Perception Questionnaire. This was far higher than any other district, the closest of which had three items (13\%). The former district has a chancellor who has been in the position for four years. Both presidents have worked for him for his entire tenure although one of the presidents worked in another administrative capacity for three of those years. One president and the chancellor agreed that the needs of the district should take priority over those of the colleges and one had disagreed with this statement. This district's assumption was that the presidents have a lower level of decision-making power at the college level than the presidents perceived they have. This was atypical of other chancellors' assumptions for 
their districts. The same district also had a high number of discrepancies at the districtwide level of decisionmaking. This will be discussed in the next section. Two of the 11 districts showed no college level discrepancies at al1.

Hypothesis 4 was tenable at the college level for $100 \%$ of the items within the planning category, $95 \%$ of the items within the finance category, $93 \%$ of the items within the communications category, $82 \%$ of the items within the external relations category, $86 \%$ of the items within the leadership category, and $98 \%$ of the items within the evaluation category.

Districtwide decision-making involvement. There were far more discrepancies at the districtwide level than at the college level. Of 264 possible responses to the 24 items, $27 \%$ showed discrepancies between the district's assumptions and college presidents regarding the presidents' decision-making involvement at the districtwide level. This compares with just over $14 \%$ discrepancies at the college level. It must be noted, however, that these percentages were not evenly distributed among the districts and there were a greater number of discrepancies in some districts than in others.

At the districtwide level, all six functional categories showed operationally significant discrepancies by two or more districts, as compared with just one category at the college level. 
In the planning category, four districts (36\%)

identified non-congruence on two or more items. Within that category, item lc, planning of physical facilities, appeared as a discrepancy in 6 (55\%) of the 11 districts. It might be speculated that the uncertainty of state funding for facilities may have influenced the responses. Within each of the categories of finance, communications, and external relations, $27 \%$ of the districts showed discrepancies on two or more of the four items. On item $2 c$ in the finance area, activities concerning budget administration, 6 (55\%) of the 11 districts showed disagreement between the district's assumptions and the presidents' perceptions of the presidents' decision-making involvement at the districtwide level. This finding is distracting since in all of the districts, there is a high level administrator who coordinates the budget districtwide. Activities concerned with the improvement of communication networks, item $3 d$, was an area in which five districts (45\%) showed discrepancies.

In one district where there had recently been a change from a multi-campus to a multi-college organizational structure, the district's assumptions for all items in the functional category of communications and three of the four items in the finance category, districtwide, were higher than the presidents' perceptions. However, there was an acting chancellor in that district who had been in that role for only a few months. 
One district showed 11 discrepancies which represented $46 \%$ of the total number of items on the Role Perception Questionnaire. This was the same district that had seven discrepancies at the college level.

Another district had 12 (50\%) districtwide level discrepancies while only one was noted at the college level. That district had both a chancellor and president who had been in these positions for less than one year. The response ratings of that college president was generally lower than that of the other president in the district which, in turn, was lower than the district's assumptions in all but the evaluation category.

Two other districts had nine items in which discrepancies occurred and one had seven (see Table 6). The remaining districts ranged from two to five item discrepancies.

Hypothesis 4 was tenable at the districtwide level for $68 \%$ of the items in the planning and finance categories; $70 \%$ of the items in the communications category, $75 \%$ of the items in the external relations and evaluation categories, and $82 \%$ of the items in the leadership category. The analyses suggested that Hypothesis 4 be rejected in the planning and finance categories since within each of these categories are specific items which showed discrepancies in more that half of the districts. 
Table 6

Multi-College Districts exceeding 25\% Discrepancies on Items at the Districtwide Level, and Years of Administrative Service

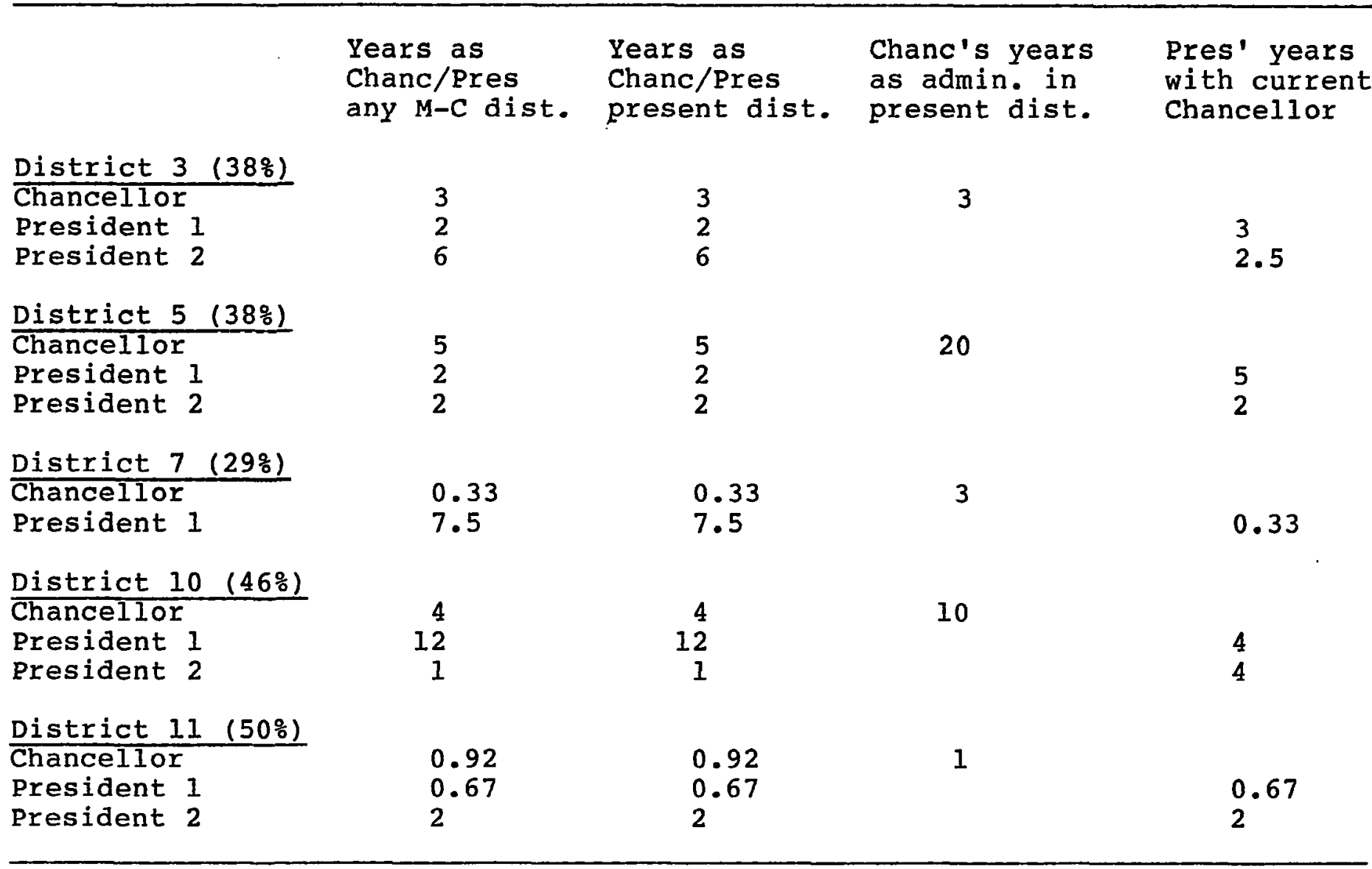

Percentages indicate item discrepancies 
Professional Background Questionnaire

The purpose of the Professional Background Questionnaire was to provide descriptive data about chancellors and presidents in the 11 districts in which the chancellor and at least one president responded.

Summary data for each question for the 11 chancellors and 22 presidents within the 11 districts is presented herewith.

Analysis of Chancellors' Responses

1. How long have you been a chancellor in a multi-college district?

The chancellors had a mean of 4.31 years and a median of 4 years as chancellors of multi-college districts. The range was from 2 months to 13 years.

2. How long have you been a chancellor in this district?

Chancellors averaged 3.85 years with a median of 4 years in their present positions. The range was from 2 months to 13 years.

3. How long have you worked in an administrative position in this district?

Chancellors had worked in administrative positions in the same district for an average of 10.63 years with a median of 8 years and a range from 1 year to 30 years. of the 11 chancellors responding, six (55\%) had worked in the district in a different capacity from 2.9 to 28 years with a mean of 12 years prior to becoming chancellor of that district, two had worked for less than one year prior to 
becoming chancellor and three had not worked in the district prior to becoming chancellor. In all, $73 \%$ of the chancellors responding had worked in the same district in an administrative capacity prior to becoming chancellor.

4. What position did you hold directly before your present position?

Three chancellors had previously been presidents within the same multi-college district (one for only one month), two had held posts as superintendent/presidents of single college districts, one had been a university president and one had been a chancellor of another multi-college district. In all, seven $(64 \%)$ had been presidents or chancellors of a college or college district, and four (36\%) had been vice-chancellors or assistant chancellors.

5. If you held your former position for less than two years, what was your position prior to that time?

There were two responses to this question. The district chancellor who had held the position of president for one month prior to becoming chancellor, had been a president for 10 years in another state. One who had been a vice-chancellor had previously served as the executive director of a community college statewide association for four years.

6/7. Have you held an administrative position at a campus in a multi-college district? If yes, was it a staff or line position? 
Nine (82\%) previously had administrative experience at a campus in a multi-college district. of those all had either line, or staff and line positions.

8. Have you had administrative experience (dean or above) in a single college district?

of the 11 chancellors, nine (82\%) had held positions of dean or above in single college districts. Only two chancellors had held no administrative position on a campus in a single or multi-college district.

9. What skills do you have that contribute to your effectiveness in your present role?

Communication and interpersonal skills were mentioned most often. Organization skills, leadership and experience also appeared frequently in the responses.

10. Do you agree that the needs and priorities of your district take priority over aspirations of the individual colleges? Should they? Other comments.

Five chancellors (45\%) responded positively that district needs take priority over those of the individual colleges. Three, (27\%) responded negatively to this question, while three did not respond directly but qualified their responses in the comments section. Analysis of Presidents' Responses 1. How long have you been a president in a multi-college district?

Presidents' responses ranged from 2 months to 20 years. The mean was 6.39 years and the median 5 years. 
2. How long have you been president in this district?

All but two of the presidents had their entire presidential experience at the college in which they were presently working. Their mean was 6.12 years and the median 4 years.

3. How long have you worked in an administrative position in this district for this chancellor?

Presidents had worked in administrative positions for the existing chancellor an average of 3.6 years. The median was 4 years and the range was from two months to eight years.

4. What position did you hold directly before your present position?

Prior to assuming their present positions, two had been presidents of community colleges, and one an acting college president. Ten ( $45 \%$ ) had been vice-presidents or deans of instructional or academic affairs; three deans in the student services area; four assistant or associate superintendents or vice-chancellors; one a director of research and planning. One who had most recently been an instructor, had prior administrative experience. 5. If you held your former position for less than two years, what was your position prior to that time?

Four presidents responded to this question. One had been assistant to the president; one an associate dean; and one a director of an extended day program.

6. Have you held an administrative "central office" 
position in a multi-college district?

Nineteen of the 22 presidents ( $86 \%$ ) had no central office experience.

7. Was it a staff or line position?

Two had held staff positions and one a line position.

8. Have you had administrative experience (dean or above)

in a single college district?

Twelve (54\%) had no administrative experience in single college districts.

9. What skills do you have that contribute to your effectiveness in your present role?

The skills most frequently mentioned were communication, interpersonal relations, financial, organizational and planning.

10. Do you agree that the needs and priorities of your district take priority over aspirations of the individual colleges? Should they? Other comments.

Sixteen (73\%) of the presidents indicated that district needs took priority over college needs, and all but three of those felt they should. Another three indicated that district needs did not and should not take priority. six of the respondents added that there must be a balance, since the needs of the district should evolve from the needs of the individual colleges. 
District Profile sheet

The purpose of the District Profile sheet was to gather descriptive information about each of the districts whose chancellor and at least one president had responded to the Role Perception Scale and Professional Background Questionnaire. The information was gathered from the California State Chancellor's Office, The Association of California Community College Administrators and individual districts' central administrative offices. The data presented concerning each district's size (average daily attendance) was based upon 1984-85 figures from the state Chancellor's office. Information about districts' organizational structures was taken from current organization charts.

Four areas that had previously been cited in the literature as having a connection to multi-college districts' organizational effectiveness, were examined by the researcher. These were district size, district age (history), location of the district office and administrative reporting relationships. District Size

Seven districts governed two colleges and four governed three colleges.

$A D A$, the unit used to measure full-time equivalent students, ranged from districts with approximately 8,000 ADA to those with close to 23,000 ADA. The mean was 14,545 ADA. 
District Age

The oldest multi-college district had been established as such in 1964, thus making it 22 years old at the time of this writing. The newest was established in 1985, as a result of its changing from a multi-campus institution with two branch campuses, to a district with two colleges.

The oldest college in this study had been established in 1922, and the newest, except for the two previously mentioned, in 1979 .

\section{District Office Location}

Five district offices are located on college campuses, while six are located elsewhere.

\section{Administrative Reporting Relationships}

Ten of the 11 districts, or $91 \%$ had vice-chancellors or assistant chancellors/assistant superintendents reporting directly to the district chancellor. These positions were on the same organizational level as the college presidents in these districts. In the eight districts where administrative salary information was made available through the ACCCA Management Report (1985-86), only one district reported a vice-chancellor's salary to be higher than its presidents' salaries. This in fact may be because the district has recently changed from a multi-campus organizational structure to a multi-college structure. Two districts reported the same salaries for presidents and vice-chancellors, but one of these provided the president with an automobile. 
Seven districts had a vice-chancellor for business or finance. A few districts also had high level managers in areas such as personnel, instruction, data processing, administrative services and legal services.

Four districts had vice-chancellors who supervise most district functions. All presidents of the multi-college districts surveyed report directly to the chancellor.

\section{Summary}

\section{Statewide Findings}

1. Multi-college district chancellors and presidents were in general agreement about the presidents' overall decision-making involvement at the college level. They showed less agreement about the presidents' decisionmaking involvement at the districtwide level.

2. Evaluation was the only functional category at the college level where statistically significant differences occurred between multi-college district chancellors and presidents. This category also showed significance at the districtwide level.

3. Multi-college district chancellors and presidents agreed that presidents have a great deal of decision-making involvement to total involvement on most items at the college level.

4. There was far less agreement on functional categories and on items within those categories at the district level of decision-making than at the college level. 
Al1 but the categories of finance and external relations showed statistically significant discrepancies between chancellors and presidents at the district level. There were, however, operationally significant discrepancies in the finance category within individual districts (see the next section).

5. In the area of external relations, both chancellors and presidents agreed that the presidents have limited formal responsibility at the district level.

6. Chancellors and presidents held strongly divergent views on an item concerning budget preparation and another on organizational evaluation at the districtwide level. A majority of chancellors felt the presidents have a great deal of involvement in these areas while a minority of the presidents shared that view. Individual District Findings

1. Chancellors had an average of just under four years in their present positions. Most had worked in an administrative capacity in the same district prior to becoming the chief executive officer. They saw skills such as communication, interpersonal relations, organization, leadership and experience as contributing to their effectiveness. They were divided equally about whether districtwide needs took priority over those of the individual colleges.

2. Presidents averaged 5.5 years in their present position and had worked in an administrative role for the 
current chancellor for four years. The vast majority had no district office experience. Presidents saw skills such as communication, interpersonal relations, financial, organization and planning as contributing to their effectiveness. Seventy-three percent of the presidents indicated that district needs take priority over those of the individual colleges.

3. Districts ranged in size from approximately 8,000 to 23,000 ADA. For the most part, they were well established with district offices located both on and off college campuses. All but one district had either vice-chancellors or assistant chancellors reporting directly to the chancellor. In only one reporting district was the salary of that individual higher than the presidents' salaries in that same district. In all districts, there was a high level manager that supervised the business function. All presidents reported directly to the chancellor.

4. The presidents' perceptions of their decision-making involvement at the college level were, in general, congruent with the districts' assumptions about that involvement.

5. The most number of discrepancies at the college level were in the external relations category. Within that category, the item dealing with state agencies, leaders and specific officeholders showed the greatest disparity.

6. There were many more discrepancies found at the districtwide level between the presidents' perceptions of their decision-making involvement and the district's 
assumptions of that involvement.

7. Planning of physical facilities and budget administration were the two items showing discrepancies at the districtwide level among the majority of the districts.

8. The two districts showing most congruence had. no discrepancies at the college level and only three and two, respectively, at the districtwide level.

9. In one district, there were discrepancies on $50 \%$ of the items at the districtwide level. Most of these fell in the categories of leadership and evaluation. Within this district, both the chancellor and one president had been in their respective positions for less than one year.

10. One district was found to have a large number of item discrepancies at both the college and districtwide levels. Twenty-nine percent of its college level responses and forty-six percent of its districtwide level responses showed discrepancies. There was no evidence that either the chancellor's or presidents' professional background, or district demographics, had any relationship to the large number of discrepancies.

11. In a district in which an acting chancellor had been in his position for only a few months, the district's assumptions about the level of the presidents' decisionmaking involvement districtwide were higher on most items than the president's perceptions. However, it must be noted that only one president in this district responded to the survey. 
12. With the exceptions noted above, no district characteristics (district size, age, district office location and administrative reporting relationships) appeared to be related to the perceptual congruities or differences found in this study. 


\begin{abstract}
Chapter V
DISCUSSION OF FINDINGS, CONCLUSIONS AND RECOMMENDATIONS
\end{abstract}

\begin{abstract}
Nature and Purpose of the study
Multi-college district organizational structures in community college systems have unique governance patterns which may carry with them ambiguities in the decision-making process. Since the college presidents' decision-making authority in such systems is delegated by the chancellor of the district, a dependency relationship exists that may affect efficiency and effectiveness within individual colleges and districtwide.

Although much of the research in this area has concentrated on the issue of district centralization versus campus autonomy, this study focused instead on the ambiguities of perceptions that may occur in key functional areas between chancellors and presidents. Within a multi-college district, conflicts may arise between the colleges and central office when there is a lack of understanding of the basic assumptions of the organization as a whole. If the chancellor has not adequately communicated the district's assumptions about the decision-making involvement of the college presidents, such conflicts can result in dysfunctional ambiguities.
\end{abstract}


Understanding and buying into these assumptions are key to maximizing organizational effectiveness in a multi-college district to ensure that the three foundational principles of such districts will prevail:

1. Efficiency of programs and services.

2. Consistency of policy and practice districtwide.

3. Campus initiative.

The premise of the study, then, was that congruity of perceptions between chancellors and presidents regarding the presidents' decision-making involvement will result in a better functioning district organization, whether or not that district's assumptions espouse strong central governance or maximized campus autonomy. The purpose of the study was to provide foundational information concerning perceptual differences and congruities between chancellors and presidents in six functional areas. This information will enable future studies to examine more closely the relationship of those differences or congruities to organizational effectiveness. An effort was made to determine if any factors pertaining either to the chancellors' or presidents' professional background, or to district characteristics, had an influence on perceptual differences or congruities. Since previous studies had concluded that such factors can influence the level of campus autonomy in multi-unit districts, information regarding these factors was gathered by the researcher. 
The general research questions posed by this study were:

1. Will there be differences statewide between the district chancellors' and college presidents' perceptions of the presidents' decision-making involvement at the college and district levels? Will there be differences within each multi-college district?

2. Within which decision-making functional areas, and at what level are there differences between multi-college district chancellors and college presidents?

3. What external factors pertaining to the professional background of the respondents, and district characteristics might help explain congruities or differences in perceptions?

\section{Discussion of Findings}

\section{Differences and Congruities: Statewide}

The 11 chancellors and 28 presidents included in the study were in overall agreement about the presidents' decision-making involvement at the college level but not at the districtwide level.

For the most part, both chancellors and presidents judged the presidents' decision-making role at the college level to be very high. Since community college presidents' position descriptions formed the basis of the items on the Role Perception Questionnaire to which chancellors and presidents responded, it can be concluded that both 
accurately reflected the role of the presidents at the college level. Although the chancellors and presidents agreed on $83 \%$ of the items dealing with the presidents' decision-making involvement at the college level, there were some discrepancies that are worth noting. These included matching budget to program, relationships with student groups, and items dealing with the evaluation of organizational operations and problems.

In some multi-college districts, presidents feel somewhat detached from the formation of the budget. All multi-college districts in California have a high level district administrator who has fiscal responsibility districtwide. The lack of congruence in "matching program to budget" might be a reflection of the ambiguity of the president's involvement in this area, even on his or her own campus.

Chancellors felt, in general, that presidents have more direct involvement with student groups than the presidents perceived they have. The isolation of the chancellors from the colleges may be a factor contributing to these perceptions. The post Proposition $13 \mathrm{climate}$ has increased the involvement of chancellors with budgetary matters, which may partially explain the disparity between chancellors and presidents in the area of matching budget to program at the college level. Jensen's 1984 study found, "The majority of the chief executives of the districts felt they were too far removed from the campuses" (p. 36). 
The researcher has found in her experience in multi-college districts that generally speaking, little time is spent on formal evaluation of the organization, unless dysfunctional elements interfere significantly with the efficient operation of the college. The ambiguity shown in this area may also be a result of conflicting definitions of "evaluation" by chancellors and presidents, rather than simply a quantitative reflection of the level of evaluation at the colleges.

Since there were few item responses that showed discrepancies between chancellors and presidents at the college level, an assumption can be made that the role of the presidents at their campuses is clearly understood. More discrepancies were found statewide between chancellors' and presidents' perceptions regarding the presidents' decision-making involvement at the districtwide level than were found at the college level. It is important to reiterate that the issue was not whether the chancellors felt presidents should have more or less decision-making authority but rather it was whether or not there was agreement between both groups about the level of authority they do have.

Whereas the presidents and chancellors were in agreement on all but one category and four items at the college level, there was disagreement on four categories and eight items at the districtwide level. Although the position description of the presidents delineated their 
decision-making role at their colleges, there was no such delineation of that role at the district level; yet, each president indicated that he or she was a member of the chancellor's cabinet, and participated in the policy level decision-making process for the entire organization.

Statewide, there were discrepancies on one-third of all districtwide level responses to items on the Role Perception Questionnaire. A closer review indicated that the functional categories of educational leadership and communication contained five of those items.

No clear directional patterns emerged in these responses relative to the chancellors and presidents views on the level of decision-making involvement in these two areas. Gross (1958) in his study of the role relationship between school superintendents and school board members found,". - a lack of consensus among group members in their role definitions is a major dysfunctional element affecting the achievement of a group's goals" (p.177). This is not to say that a formal delineation of the presidents' role at the districtwide level would automatically achieve congruity of perceptions, but if, as 01swang states,". . consensus of understanding is a prerequisite to good communication" (1977, p.118), then at least the foundation would be in place. Differences and Congruities: Individual Districts

Changing the focus of the research problem from a statewide point of view to an individual district 
perspective, brought with it some subtle changes. The "chancellor's perspective" of the presidents' decisionmaking role in his or her own district was transformed into the "district's assumptions" about that involvement. Although one might suspect that the longer the chancellor (as a leader) has held his or her position, the more likely his or her views would be embedded in the culture of the organization, and the better articulated the assumptions would be, this was not immediately apparent in the study. Generally speaking, there appeared to be as many discrepancies noted at both the college and districtwide levels in individual districts where the chancellor had held that position for more than five years, as there were in districts where the chancellor had been in the job only two months.

But this finding can be misleading. A closer investigation of background information indicated that within the 11 individual districts studied, $73 \%$ of the chancellors and $63 \%$ of the presidents have held other administrative positions in the same districts, with another $14 \%$ of the presidents coming from other California multicollege districts. For all but one in each group, their careers as chancellors and presidents had started at the institution in which they are now employed. And $82 \%$ of the presidents within these districts have worked for the same chancellor for two or more years. As a result, the chancellors have had ample opportunities to communicate 
district assumptions to their presidents, who have enough longevity in the district to understand and to deal with those assumptions. It must be assumed, also, that both chancellors and presidents have a good understanding of the constraints and benefits of the multi-college district structure.

The researcher cautions about conclusions being drawn strictly on the basis of length of service and familiarity of surroundings, however, because of the small numbers in the population and the variety of factors pertaining to leadership style and organizational culture that were not included in the study.

A good example about drawing such conclusions is exemplified by the diversity of two districts in the study, each of which showed total congruence between the chancellor's and presidents' perceptions at the college level and almost total congruence at the districtwide level. In one of these districts was a chancellor who had been in his position for eight years, and two presidents who had been in their positions for three years and seven years respectively. It was one of the largest districts in the study with a large central office administrative staff. The other district had a chancellor who had been in his role only two months and in the district only one year. Both presidents in the latter district had been in their positions eight and nine years respectively. It was one of the smaller districts in the study and had a small central 
office administrative staff. In this instance, it would appear that factors beyond the scope of this study may have been related to the congruity of perceptions. The most powerful primary mechanisms for culture embedding and reinforcement are (1) what leaders pay attention to, measure, and control; (2) leader reactions to critical incidents and organizational crises; (3) deliberate role modeling, teaching, and coaching by leaders; (4) criteria for allocation of rewards and status; (5) criteria for recruitment, selection, promotion, retirement, and excommunication (Schein, 1985, pp.224-225). None of these factors were included as part of this research. Although both the presidents' perceptions and the districts' assumptions showed almost total congruity at the college level, there was one operationally significant finding worth noting, namely external relations.

A review of individual districts indicates there were a number of districts showing item discrepancies in the external relations category at the college level. Clearly, there was some uncertainty between chancellors and presidents about the presidents' decision-making involvement with outside agencies. Of particular interest was the item dealing with activities with state agencies, leaders, and specific officeholders. In recent years, CEOs in California community colleges have become more politically involved at the state level. The confusion between chancellors and 
presidents might result from uncertainty about whether college or district leaders in multi-college districts should take the principal role in California's legislative arena.

At the districtwide level, there were discrepancies in enough areas to warrant further discussion about the decision-making involvement of the presidents in the total district organization.

Fifty-five percent of the districts showed discrepancies at the districtwide level on two items. The first dealt with planning of physical facilities. Uncertainty about state funding in this area might have contributed to the disparity between district assumptions and presidents' perceptions. It may be speculated that some of the respondents were comparing the president's decision-making authority with that of forces beyond the control of the district, while others were looking only at the presidents' decision-making role within the district. The other item showing a great number of discrepancies referred to activities concerning budget administration. since all California multi-college districts have a high level budget administrator at the district level, the ambiguity of responses may be related to how the chancellor and presidents perceive the authority of that administrator, and how the presidents interact with that individual. There was a far greater range of responses in assessing the districtwide decision-making involvement of the 
presidents than there had been at the college level, where almost all items had been rated 4 or 5 on the 5 -point scale by both chancellors and presidents. In addition, unlike the college level, where individual district assumptions were very similar to the presidents' perceptions, no clear pattern emerged at the districtwide level.

\section{Conclusions}

Several conclusions can be drawn from this study.

1. Chancellors and presidents in multi-college districts agree that presidents have a great deal of decision-making autonomy on their own campuses.

2. Presidents' position descriptions accurately reflect their decision-making functions at the college level.

3. The presidents' decision-making involvement at the districtwide level is not clearly defined and is in need of clarification.

4. Since a majority of chancellors and presidents in California multi-college districts have previously held other administrative positions in the same districts, there may be a relationship between that experience and their acknowledgement that districtwide needs and priorities must be placed before the aspirations of individual colleges.

5. District size, age, location of the district office, and administrative reporting relationships do not appear to be related to the perceptual differences between chancellors and presidents. 
6. Although some relationship can be drawn between the professional background of chancellors and presidents, and the congruence and discrepancies of their perceptions of the presidents' decision-making role, other factors pertaining to leadership and organizational culture should be explored.

\section{Implications of the study}

In many respects, multi-college districts represent "systems within systems" (Kintzer, 1984). The college president, who operates within such a structure as both a CEO and a district manager, may be faced with role ambiguity in certain areas at both the college and district levels.

Regardless of the degree of autonomy or centralization in a multi-college district, it is important that the role of the college president is clearly understood and is consistent with district assumptions about that role. The results of this study indicate that the presidents' decision-making role is, on the whole, clearly defined and operationally functional at the college level. There is, however, less agreement about the presidents' decisionmaking involvement as a district manager.

The findings of this study, while reinforcing the concept of the presidents' decision-making autonomy within their own institutions, do raise some other operational concerns. One of these is the issue of the role of the presidents in their colleges' external affairs, particularly in the political arena at the state level. Who speaks for 
the units within the multi-college district? Are the interests of a large, middle-class institution the same as those of a small rural college simply because they are administratively tied together? Is it better that a chancellor, who may be as Jensen (1984) has described, too far removed from the campuses, serves as spokesperson? or should the presidents of these colleges represent the special needs of their separate institutions with little thought to districtwide needs and priorities? Districts, not colleges, are recognized as the legal entities by the Legislature and State Chancellor's office. Are presidents within multi-college districts limited, therefore, in their dealings with external agencies? How does this affect the relationship between the chancellors and presidents?

since this study did not include large urban districts in its population, no inferences may be drawn concerning these districts. However, Buckner (1975) suggested that urban, multi-unit community college districts require more central coordination rather than individual autonomy. Whether there is more uncertainty about the presidents' decision-making role within those districts is an issue that should be explored in future studies.

A major conclusion of the study was that the presidents' decision-making involvement at the district level is ambiguous and in need of further clarification. There was an assumption in the 11 districts participating in this study, that the presidents do have some decision-making 
involvement at the district level since they, along with higher level district administrators, are part of the chancellors' policy council. The study implies that there is no formal delineation of what that involvement should be. The three categories in which there were the most discrepancies at the districtwide level were planning, finance, and communications. Although Jensen (1984) identified communications "as the greatest single problem that plagues multi-campus institutions" (p.34), most chancellors and presidents in the study believed that their personal communication skills are major contributors to their effectiveness. It may be concluded that these skills need to be applied to the articulation of the presidents' decision-making involvement at the district level as well as they appear to have been applied at the college level. Finally, the leadership of the California community college districts merits some discussion. Findings indicate that most chancellors and presidents in multi-college districts (and, in all probability, single college districts), either have moved up the administrative ladder within their own districts, or have been chosen for their positions from other California community college districts. Such homogeneity of leadership no doubt contributes to a strong organizational culture, i.e., those shared assumptions by both chancellors and presidents that guide the perceptions of other members of the organization, from which in turn, will come its future leaders. Schein (1985) 
describes it succinctly. ". . we must understand this paradox: Leaders create cultures, but cultures, in turn, create leaders" (p.313).

The California legislature has shown concern that some of the basic assumptions guiding the community college mission, structure, and governance have become dysfunctional. New leadership from outside the system has challenged many assumptions of the present institutional culture, and has called for change. Whether the present California community college network of leadership has the vision and desire to respond to that challenge by changing existing assumptions, and has the ability to involve constituents in the development of a new culture, is difficult to assess. Most of the chancellors and presidents in this study shared the assumption that district needs take priority over the aspirations of individual colleges.

Is there leadership within these districts prepared to challenge the assumptions of the multi-college structure if that becomes necessary to adapt to change? or has the present culture become so embedded by past leadership that, in turn, it has irrevocably shaped the values of the present and future leadership?

\section{Recommendations}

Based upon the findings, conclusions, and implications of this study, the following recommendations are made: 
1. Since the study was limited to multi-college districts in California, it might be well for further research to analyze perceptual congruities and differences in both multi-campus and multi-college districts throughout the United States. Since there was some evidence of a relationship between administrative experience in multicollege systems and perceptual differences and congruities, this area would be worth exploring.

2. Although this study did not include large urban multi-college districts, such districts have been noted in the literature for their unique organizational and governance patterns. While researchers are divided on the benefits of centralization versus those of increased campus autonomy in urban districts, they agree that there are many issues confronting these districts that impact on their organizational effectiveness.

A study of urban districts should focus on the college presidents' decision-making role at both the college and district levels, the relationship between the college presidents and district staff, and the politicizing of the urban multi-college district.

3. The findings of the study showed uncertainty and ambiguity in college presidents' decision-making involvement at the districtwide level. It would be beneficial for chancellors in multi-college districts to review presidents' job descriptions in an effort to clarify the presidents' districtwide responsibilities. In addition, chancellors 
should discuss with their council members, the role each plays at the district and college levels, and their relationship to other high level administrators within the district. Good communication skills, though perceived by most chancellors and presidents in this study as contributing to their management effectiveness, are not in evidence at the district level of decision-making involvement of the presidents.

4. The embedded assumptions of a community college district guide its actions, decisions, and values. The richness of the research on organizational culture provides a solid theoretical base on which to conduct further studies in this area.

The present study was constructed on the premise that congruence of perceptions between the chancellor and presidents will result in shared values which, in turn, will be transformed into a strong operational philosophy. The findings indicated that four districts stood out among the others as having either a great number or very few perceptual discrepancies between chancellors and presidents. Case studies of these districts might provide some valuable insights into their organizational philosophy, and help to determine if there is a relationship between perceptual congruities and differences of chancellors and presidents and the organization's culture.

Another valuable study would be one that looks at California community colleges statewide, to see if there are 
shared institutional values and assumptions that tie the 106 colleges together, and to examine the impact a state system might have on the presence or absence of those assumptions.

5. While this study examined professional backgrounds and district characteristics and their relationship to the perceptions of the presidents' decision-making role, there are many other factors impacting california community college organizations that should be explored. Three of these mentioned briefly in this study are the increased political and fiscal roles of district chancellors, and their leadership styles. A fourth impacting element is collective bargaining. The chief negotiator may, in many respects, be instrumental in setting organizational policy which may, in turn, have an effect on the perceptions of the presidents' decision-making authority at their colleges.

The goal of this study was to provide foundational information to help point the direction for future studies in administrative decision-making within multi-college districts. It is hoped that the findings of the study will contribute to a base of knowledge that will assist others in conducting research in this area. 
APPENDICES

110

Reproduced with permission of the copyright owner. Further reproduction prohibited without permission. 
APPENDIX A

California senate Bill

SB 2064

111

Reproduced with permission of the copyright owner. Further reproduction prohibited without permission. 


\section{SB 2064 (Stiern), Chapter 1506}

Senate Bill No. 2064

\section{CHAPTER 1506}

An act relating to community colleges, making an appropriation therefor, and declaring the urgency thereof, to take effect immediately.

[Approved by Covernor September 27,1984 . Filed with Secretary of State Sepiember 28 , 1984.1

LEGISLATIVE COUNSELS DIGEST

SB 2064, Stiern. Community colleges: reassessment study.

Existing law does not provide for community college reassessment study.

This bill would provide that a Community College Reassessment Study be undertaken, and that the study be directed. by the Commission for the Review of the Master Plan established pursuant to SB 1570 of the 1983-84 Regular Session. Pursuant to the study, a report would be prepared, as specified, and submitted to the Joint Committee for the Review of the Master Plan established pursuant to ACR 162 of the 1983-84 Regular Session for its review on or before December 31, 1985. Following the legislative review, the bill would require the commission to make other specified assessments and policy recommendations.

This bill would require the commission to complete the study by December 31, 1986. This bill would not take effect unless ACR 162 and SB 1570 are both chaptered.

This bill would take effect immediately as an urgency statute.

Appropriation: yes.

The people of the State of California do enact as follows:

SECTION 1. (a) The Legislature finds and declares that the community colleges are a large and important segment of California's system of public higher education. In the last 20 years, community colleges have not only experienced tremendous growth in the numbers of students enrolled, but have undergone a major transition in the types of students served and the types of programs and courses offered. Community colleges have also experienced un unacceptable degree of uncertainty and instability in their revenues over the last decade.

(b) The Legislature further finds and declares that legislative actions regarding community colleges have not been based on a comprehensive policy on the role that community colleges should play in public education. Community colleges have been reacting and responding to narrow changes in state policy that have shaped the functions of the colleges by defultt. rather thin by design. 
Ch. 1506

(c) It is, therefore, the intent of the Legislature to require the Commission for the Review of the Muster Plan for Higher Education established pursuant to Senate Bill 1570 of the 1983-84 Regular Session to cet the reassessment of the mission of the community colleges as its first and highest priority.

SEC. 2. The study described in this act shall be conducted as follows:

(a) The study shall be an assessment of the mission of the community colleges. The assessment shall include, but not be limited to, all of the following:

(1) A comparison of the statutory directives regarding the programs and activities required to be offered by community colleges, and the programs and activities actually offered by community colleges.

(2) An assessment of, and recommendations regarding, the appropriateness of all of the following programs, courses, and activities to the mission of the community colleges, particularly with respect to the functions of other state educational institutions, and the priorities which should be given to all of the following programs, courses, and activities:

(A) Transfer programs.

(B) Vocational programs.

(C) Programs leading to associate degrees.

(D) Certificate programs leading to employment.

(E) General education courses.

(F) Remedial and basic skills courses.

(G) Noncredit courses.

(H) Fee-supported community services courses.

(I) Student services, including, but not limited to, counseling, testing, job placement, and financial aid.

J) Other programs, courses, and activities currently offered by community colleges.

(3) An assessment of the current socioeconomic composition of community college students, and recommendations for methods to ensure that all California residents will have access to community college programs and services.

(4) Policy recommendations designed to ensure that the academic quality of community college programs and courses will be maintained and enhanced.

(3) Other policy recommendations regarding the mission of the community colleges or community college operations the commission deems appropriate.

(b) On or before December 31, 1985, the commission shall submit the findings and recommendations developed pursuant to subdivision (a) to the Joint Committee for the Review of the Master Plan for Postsccundary riduciltion.

SFic: 3. The reassessinent study, as specified in Section 2 of this act. shall br directed by the Commission for the Reviru of the Master 


\section{Plan for Higher Education.}

SEC. 4. Upon completion of the reassesoment study authorized by this act, all of the documents and working papers of the commission shall become the property of, and be muintained by, the State Archives.

SEC. 5. This bill shall not take effect unless Assembly Concurrent Resolution 162 and Senate Bill 1570, both of the 1983-84 Regular Session, are also chaptered.

SEC. 6. This act is an urgency statute necessary for the immediate preservation of the public peace, health, or af fety within the meaning of Article IV of the Constitution and shall 80 into immediate effect. The facts constituting the necessity are:

In order that the reassessment study required by this act mny be completed as expeditiously as possible so that the importent problems facing community colleges may be addressed, it is necessary that this act take effect immediately. 
APPENDIX B

Survey Instruments

115

Reproduced with permission of the copyright owner. Further reproduction prohibited without permission. 
(Chancel1or)

QUESTIONNAIRE

PERCEIVED DECISION-MAKING ROLE OF THE COLLEGE PRESIDENT

The purpose of this study is to identify the perceptions of community college presidents and chancellors regarding the decision-making involvement of college presidents in multi-college districts. You are asked to respond as a chancellor of such a district. Responses will be treated in a confidential manner, with no identification of the college or district appearing in the study.

Items have been drawn from the literature and general position descriptions of college presidents. These items are grouped into functional categories and listed on this questionnaire. Please do not discuss your responses with anyone, since the study is based upon your own perceptions of the presidents' decision-making role. If you would like a copy of the results of the survey, please complete and mail the postcard enclosed.

\section{Instructions:}

There are six categories of executive functions listed in this survey, with more specific items contained within each category. Please identify the decision-making involvement you feel your presidents have for each of the items listed, at the college level and districtwide. Rate each item from 1 "no involvement" to 5 "total involvement." Remember, the survey is seeking your perceptions of your presidents' decision-making involvement.

\section{Definitions:}

INVOLVEMENT is defined here as playing a significant role in the decision-making process.

COLLEGE INVOLVEMENT refers to the significant decision-making role you feel your presidents play at their own colleges.

DISTRICTWIDE INVOLVEMENT refers to the significant decision-making role you feel your presidents play within the entire district organization, including the other colleges, centers, and the central office.

PLEASE RETURN THE COMPLETED SURVEY IN THE ENVELOPE PROVIDED BY APRIL 21st. THANK YOU. 


\begin{tabular}{|c|c|c|c|c|}
\hline 1 & 2 & 3 & 4 & 5 \\
\hline $\begin{array}{c}\text { NO } \\
\text { INVOLVEMENT }\end{array}$ & $\begin{array}{c}\text { SOME } \\
\text { INVOLVEMENT }\end{array}$ & $\begin{array}{l}\text { MOOERATE } \\
\text { INVOLVEMENT }\end{array}$ & $\begin{array}{l}\text { A GREAT DEAL OF } \\
\text { INVOL VEMENT }\end{array}$ & $\begin{array}{c}\text { TOTAL } \\
\text { INVOLVEMENT }\end{array}$ \\
\hline
\end{tabular}

1. PLANNING: Serving an important leadership role in setting direction for the implementation of policy for the furtherance of both immediate and future goals and purposes.

$$
\begin{array}{cc}
\text { COLLEGE } & \text { DISTRICTWIDE } \\
(1-5) & (1-5)
\end{array}
$$
a. Future or long-range planning activities
b. activities related to program expansion, addition, reduction, and contraction
c. planning of physical facilities for the present and immediate future
d. setting operational priorities

2. FINANCE: The acquisition and allocation of income resources for operation and goal attainment. This includes decision-making activities in budget preparation, and budget administration.

$$
\begin{array}{cc}
\text { COLLEGE } & \text { DISTRICTWIDE } \\
(1-5) & (1-5)
\end{array}
$$
a. activities concerning budget preparation
b. activities related to matching budget to program
c. activities concerning budget administration
d. activities related to the priority ranking of resource allocation levels




$\begin{array}{cccc}\text { NO } & \text { SOME } & \text { MODERATE } & \text { A GREAT } \\ \text { INVOLVAL OF } & \text { TOTAL } \\ \text { INVOLVEMENT } & 5 & \text { INVOLVEMENT }\end{array}$

3. COMMUNICATION OF POLICIES AND DECISIONS: efforts to clarify the decisionmaking process and to obtain overall acceptance of this process and general policies made through this process.

$$
\begin{array}{cc}
\text { COLLEGE } & \text { DISTRICTWIDE } \\
(1-5) & (1-5)
\end{array}
$$
a. activities pertaining to the maintenance of openness in the decision-making process
b. activities concerning cooperative partici- pation in governance
c. activities concerning improving human relations or general morale
d. activities concerned with the improvement of communication networks

4. EXTERNAL RELATIONS: Interaction with individuals and agencies external to the district but that are potentially important to its operation and goal attainment; this includes goverment agencies and leaders at all levels, business and cormunity leaders, and any other important elements of the community that may affect the college or district in some way.

$$
\begin{array}{cc}
\text { COLLEGE } & \text { DISTRICTHIDE } \\
(1-5) & (1-5)
\end{array}
$$

a. activities concerning accrediting agencies

b. activities involving state agencies, leaders and specific office holders

c. activities concerning groups, leaders, events within the local community or district

d. activities with various professional associations or other educational leaders in the state or nation 


\begin{tabular}{|c|c|c|c|c|}
\hline-1 & $-^{2}$ & 3 & $\Omega^{4}$ & 5 \\
\hline $\begin{array}{l}\text { NO } \\
\text { INVOLVE }\end{array}$ & $\begin{array}{c}\text { SOME } \\
\text { INVOLVEMENT }\end{array}$ & $\begin{array}{l}\text { MODERATE } \\
\text { INVOLVEMENT }\end{array}$ & $\begin{array}{l}\text { A GREAT DEAL OF } \\
\text { INVOLVEMEHT }\end{array}$ & $\begin{array}{c}\text { TOTAL } \\
\text { IHVOLVEMENT }\end{array}$ \\
\hline
\end{tabular}

5. EDUCATIONAL LEADERSHIP: Providing direction for the various institutional constituencies by serving as a facilitator and catalyst for effective and efficient operation; serving an important role in coordination, organization, and motivation.

$$
\begin{array}{cc}
\text { COLLEGE } & \text { DISTRICTHIDE } \\
(1-5) & (1-5)
\end{array}
$$

a. presenting policy recomendations and alternative strategies to the Board of Trustees

b. activities concerning the initiation of educational policy and innovations in programs, operations, and management techniques

c. activities involving adninistration, faculty, and staff; providing motivational leadership and support on their behalf

d. activities with student groups, councils, and individuals of the student body

6. EVALUATION: The process of making judgments and basic determinations regarding the effectiveness and efficiency of operational aspects, and those aspects related to personnel within the organization.

a. activities regarding decisions or evaluative

$$
\begin{array}{cc}
\text { COLLEGE } & \text { DISTRICTWIDE } \\
(1-5) & (1-5)
\end{array}
$$

judgments on the progress of the organization

b. activities concerning evaluative judgments on the efficiency of organizational operations

c. activities relating to judgnents on personnel matters

d. activities concerning the assessment of perceived or real problems within the organization 


\section{PROFESSIONAL BACKGROUND QUESTIONNAIRE - CHANCELLOR}

1. How long have you been a Chancellor in a multi-college district?

2. How long have you been Chancellor in this district?

3. How long have you worked in an administrative position in this district?

4. What position did you hold directly before your present position?

5. If you held your former position for less than two years, what was your position prior to that time?

For how long?

6. Have you held an administrative position at a campus in a multi-college district?

7. If yes, was it staff position or a line position?

8. Have you had administrative experience (dean or above) in a single-college district?

9. What skills do you have that contribute to your effectiveness in your present role?

10. Do you agree that the needs and priorities of your district take priority over aspirations of the individual colleges? Yes ( ) No ( ) Should they? Yes ( ) No ( ) Other comments:

\section{LAST PAGE: THANK YOU FOR YOUR COOPERATION}


(President)

\section{QUESTIONNAIRE}

\section{PERCEIVEd DECISION-MAKING ROLE OF THE COLLEGE PRESIdENT}

The purpose of this study is to identify the perceptions of community college presidents and chancellors regarding the decision-making involvement of college presidents in multi-college districts. You are asked to respond as a president within such a district. Responses will be treated in a confidential manner, with no identification of the college or district appearing in the study.

Items have been drawn from the literature and general position descriptions of college presidents. These items are grouped into functional categories and listed on this questionnaire. Please do not discuss your responses with anyone, since the study is based upon your own perceptions of your decision-making role. If you would like a copy of the results of the survey, please complete and mail the postcard enclosed.

\section{Instructions:}

There are six categories of executive functions listed in this survey, with more specific items contained within each category. Please identify the decision-making involvement you feel you have for each of the items listed, at the college level and districtwide. Rate each item from 1 "no involvement" to 5 "total involvement."

\section{Definitions:}

INVOLVEMENT is defined here as playing a significant role in the decision-making process.

COLLEGE INVOLVEMENT refers to the significant decision-making role you feel you play at your own college.

DISTRICTWIDE INVOLVEMENT refers to the significant decision-making role you feel you play within the entire district organization, including the other colleges, centers, and the central office.

PLEASE RETURN THE COMPLETED SURVEY IN THE ENVELOPE PROVIDED BY APRIL 21st. THANK YOU. 


\begin{tabular}{|c|c|c|c|c|}
\hline 1 & 2 & 3 & 4 & 5 \\
\hline $\begin{array}{c}\text { NO } \\
\text { INVOLVEMENT }\end{array}$ & $\begin{array}{c}\text { SOME } \\
\text { INVOLVEMENT }\end{array}$ & $\begin{array}{l}\text { MODERATE } \\
\text { INVOLVEMENT }\end{array}$ & $\begin{array}{l}\text { A GREAT DEAL OF } \\
\text { INVOLVEMENT }\end{array}$ & $\begin{array}{c}\text { TOTAL } \\
\text { JNYOLYEMENT }\end{array}$ \\
\hline
\end{tabular}

1. PLANNING: Serving an important leadership role in setting direction for the implementation of policy for the furtherance of both immediate and future goals and purposes.

$$
\begin{array}{cc}
\text { COLLEGE } & \text { DISTRICTWIDE } \\
(1 \cdot 5) & (1 \cdot 5)
\end{array}
$$

a. Future or long-range planning activities

b. activities related to program expansion, addition, reduction, and contraction

c. planning of physical facilities for the present and immediate future

d. setting operational priorities

2. FINANCE: The acquisition and allocation of income resources for operation and goal attainment. This includes decision-making activities in budget preparation, and budget administration.

$$
\begin{array}{cc}
\text { COLLEGE } & \text { DISTRICTHIDE } \\
(1 \cdot 5) & (1 \cdot 5)
\end{array}
$$
a. activities concerning budget preparation
b. activities related to matching budget to program
c. activities concerning budget adninistration
d. activities related to the priority ranking of resource allocation levels 


\begin{tabular}{|c|c|c|c|c|}
\hline-1 & 2 & 3 & 4 & 5 \\
\hline $\begin{array}{c}\text { NO } \\
\text { INVOLVEMENT }\end{array}$ & $\begin{array}{c}\text { SOME } \\
\text { INVOLVEMENT }\end{array}$ & $\begin{array}{l}\text { MODERATE } \\
\text { INVOLVEMENT }\end{array}$ & $\begin{array}{l}\text { A GREAT DEAL OF } \\
\text { INVOLVEMENT }\end{array}$ & $\begin{array}{c}\text { TOTAL } \\
\text { INVOLVEMENT }\end{array}$ \\
\hline
\end{tabular}

3. COMMUNICATION OF POLICIES AND DECISIONS: efforts to clarify the decisionmaking process and to obtain overall acceptance of this process and general policies made through this process.

$$
\begin{array}{cc}
\text { COLLEGE } & \text { DISTRICTWIDE } \\
(1-5) & (1-5)
\end{array}
$$

a. activities pertaining to the maintenance of openness in the decision-making process

b. activities concerning cooperative participation in governance

c. activities concerning improving human relations or general morale

d. activities concerned with the improvement of communication networks

4. EXTERNAL RELATIONS: Interaction with individuals and agencies external to the district but that are potentially important to its operation and goal attainment; this includes government agencies and leaders at all levels, business and community leaders, and any other important elements of the comunity that may affect the college or district in some way.

$$
\begin{array}{cc}
\text { COLLEGE } & \text { DISTRICTHIDE } \\
(1-5) & (1-5)
\end{array}
$$

a. activities concerning accrediting agencies

b. activities involving state agencies, leaders and specific office holders

c. activities concerning groups, leaders, events within the local community or district

d. activities with various professional associations or other educational leaders in the state or nation 


\begin{tabular}{|c|c|c|c|c|}
\hline 1 & 2 & 3 & 4 & 5 \\
\hline $\begin{array}{c}\text { NO } \\
\text { INVOLVEMENT }\end{array}$ & $\begin{array}{c}\text { SOME } \\
\text { INVOLVEMENT }\end{array}$ & $\begin{array}{l}\text { MODERATE } \\
\text { INVOLVEMENT }\end{array}$ & $\begin{array}{l}\text { A GREAT DEAL OF } \\
\text { INVOLVEMENT }\end{array}$ & $\begin{array}{c}\text { TOTAL } \\
\text { INVOLVEMENT }\end{array}$ \\
\hline
\end{tabular}

5. EDUCATIONAL LEADERSHIP: Providing direction for the various institutional constituencies by serving as a facilitator and catalyst for effective and efficient operation; serving an important role in coordination, organization, and motivation.

$$
\begin{array}{cc}
\text { COLLEGE } & \text { DISTRICTHIDE } \\
(1-5) & (1-5)
\end{array}
$$

a. presenting policy recommendations and alternative strategies to the Board of Trustees

b. activities concerning the initiation of educational policy and innovations in programs, operations, and management techniques

c. activities involving adninistration, faculty, and staff; providing motivationat leadership and support on their behalf

d. activities with student groups, councils, and individuals of the student body

6. EVALUATION: The process of making judgments and basic determinations regarding the effectiveness and efficiency of operational aspects, and those aspects related to personnel within the organization.

a. activities regarding decisions or evaluative

$$
\begin{array}{cc}
\text { COLLEGE } & \text { DISTRICTWIDE } \\
(1-5) & (1-5)
\end{array}
$$
judgments on the progress of the organization

b. activities concerning evaluative judgments on the efficiency of organizational operations

c. activities relating to judgments on personnel matters

d. activities concerning the assessment of perceived or real problems within the organization 


\section{PROFESSIONAL BACKGROUND QUESTIONNAIRE - PRESIDENT}

1. How long have you been a President in a multi-college district?

2. How long have you been President in this district?

3. How long have you worked in an administrative position in this district for the present chancellor?

4. What position did you hold directly before your present position?

For how long? Was it in this district?

5. If you held your former position for less than two years, what was your position prior to that time?

For how long?

6. Have you held an administrative "central office" position in a multi-college district?

7. If yes, was it staff position or a line position?

8. Have you had administrative experience (dean or above) in a single-college district?

9. What skills do you have that contribute to your effectiveness in your present role?

10. Do you agree that the needs and priorities of your district take priority over aspirations of the individual colleges? Yes ( ) No ( ) Should they? Yes ( ) No ( ) Other Comments:

\section{LAST PAGE: THANK YOU FOR YOUR COOPERATION}




\section{District Profile Sheet}

1. District

2. Colleges

3. Year organized as an independent multi-college district

4. Administrative district-level positions (dean level and above)
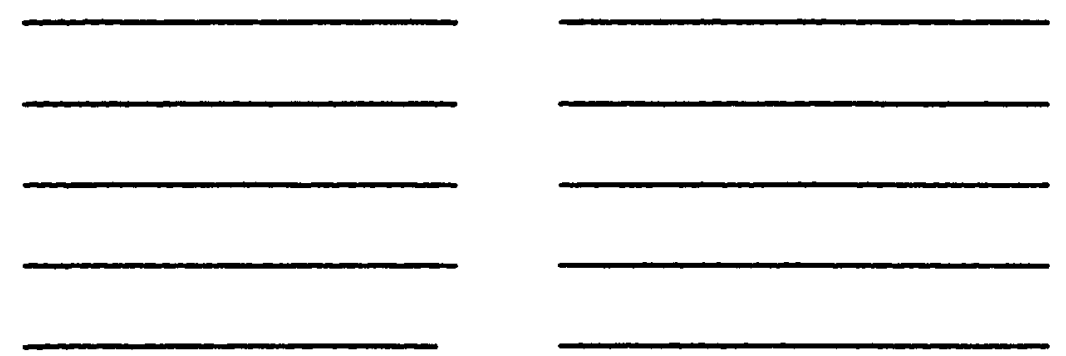

5. Comparison of highest level district salaries and presidents' salaries $(1984-85)$

Salary

Title

President:
Salary

Title

6. Location of the Central Office:

On a college campus Yes ( ) No ( ) Where

At a separate location Yes ( ) No ( ) Where

Centrally located to all:colleges Yes ( ) No ( )

7. Districtwide ADA (1984 - 85)

College ADA (1984 - 85) 
8. Administrative positions represented on Chancellor's Policy Council

9. Presidents report directly to:

10. Number of years each college has been part of the district:

College

Years 


\section{APPENDIX C \\ Cover Letter for Survey}


SCHOOL OF EDUCATION

University of San Diego DIVISION OF LEADERSHIP \& ADMINISTRATION

\author{
Dear Colleague: \\ I am writing to request your cooperation in the conduct \\ of a doctoral study titled:
}
AN ANALYSIS OF THE DIFFERENCE IN PERCEPTION BETWEEN CALIFORNIA COMMUNITY COLLEGE CHANCELLOR AND PRESIDENTS IN MULTI-COLLEGE DISTRICTS REGARDING DECISION-MAKING INVOLVEMENT OF THE COLIEGE PRESIDENTS

which is being conducted by Jeanne Atherton, a doctoral candidate at USD and Director of Instructional and Student Services in the San Diego Community College District.

This study examines an area of considerable interest and importance in community college management and we believe that the results of the study will make an important addition to the literature in the field. Your response to the survey instrument should take a minimum of time and will, of course, be held in the strictest confidence.

Thank you for your time and cooperation-it is deeply appreciated.

Sincerely,

Wallace F. Cohen

Dissertation Director

President Emeritus

Cuyumaca College

WFC: ag 


\section{Dear Colleague:}

I need your assistance! A few weeks ago you received a survey to complete which will form the basis for a study Dr. Wally Cohen and I are conducting on multi-college districts. This research will build upon the work of Arthur Jensen and Fred Kintzer who have pioneered the studies relating to this area.

Wally and I realize your time is at a premium, however your insights are valuable to our research, and we believe the results will be of interest to you as well.

I've enclosed a second questionnaire, just in case the first was mislaid. Please take ten minutes to complete the form and, if you wish, mail the post card for survey results. There is a stamped envelope for your convenience in returning your responses to us.

Thank you for your participation and contribution to our study.

PLEASE RESPOND BY MONDAY, MAY 5, 1986.

\section{Sincerely,}

Deanne L. Atherton

Director, Instructional and Student Services

Enclosures 
APPENDIX D

Statistical Computations

131

Reproduced with permission of the copyright owner. Further reproduction prohibited without permission. 
Statewide Differences ( $\underline{t}-$ test)

CHRCELLORS ARO PRESIOEMIS-SWRYEY

$06218<86$

PREE 3

FILE NOMAME (CAEATION DATE $=06 / 18 / 86)$

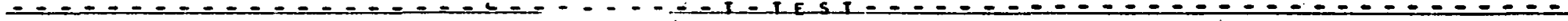
GRoup $\frac{1}{2}=$ POS POSTH

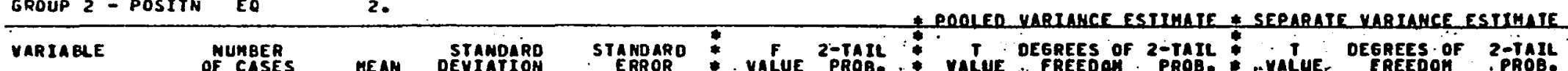

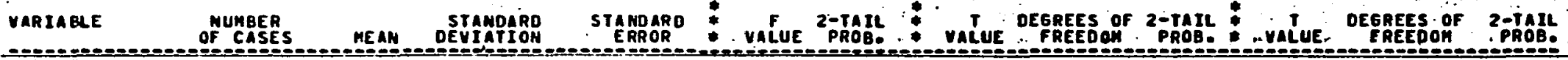

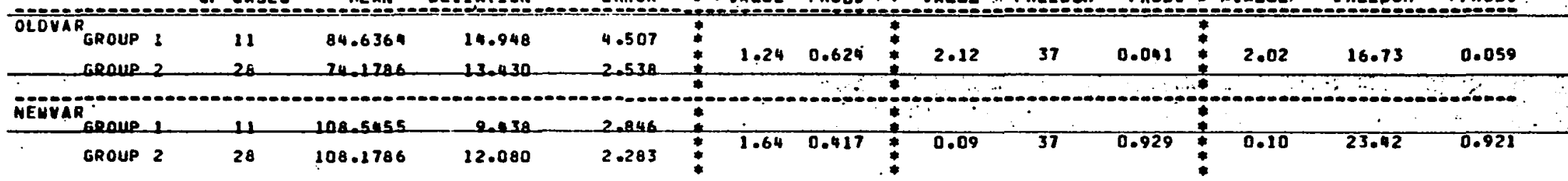

(1) 
Statewide Differences by Category (ț-test)

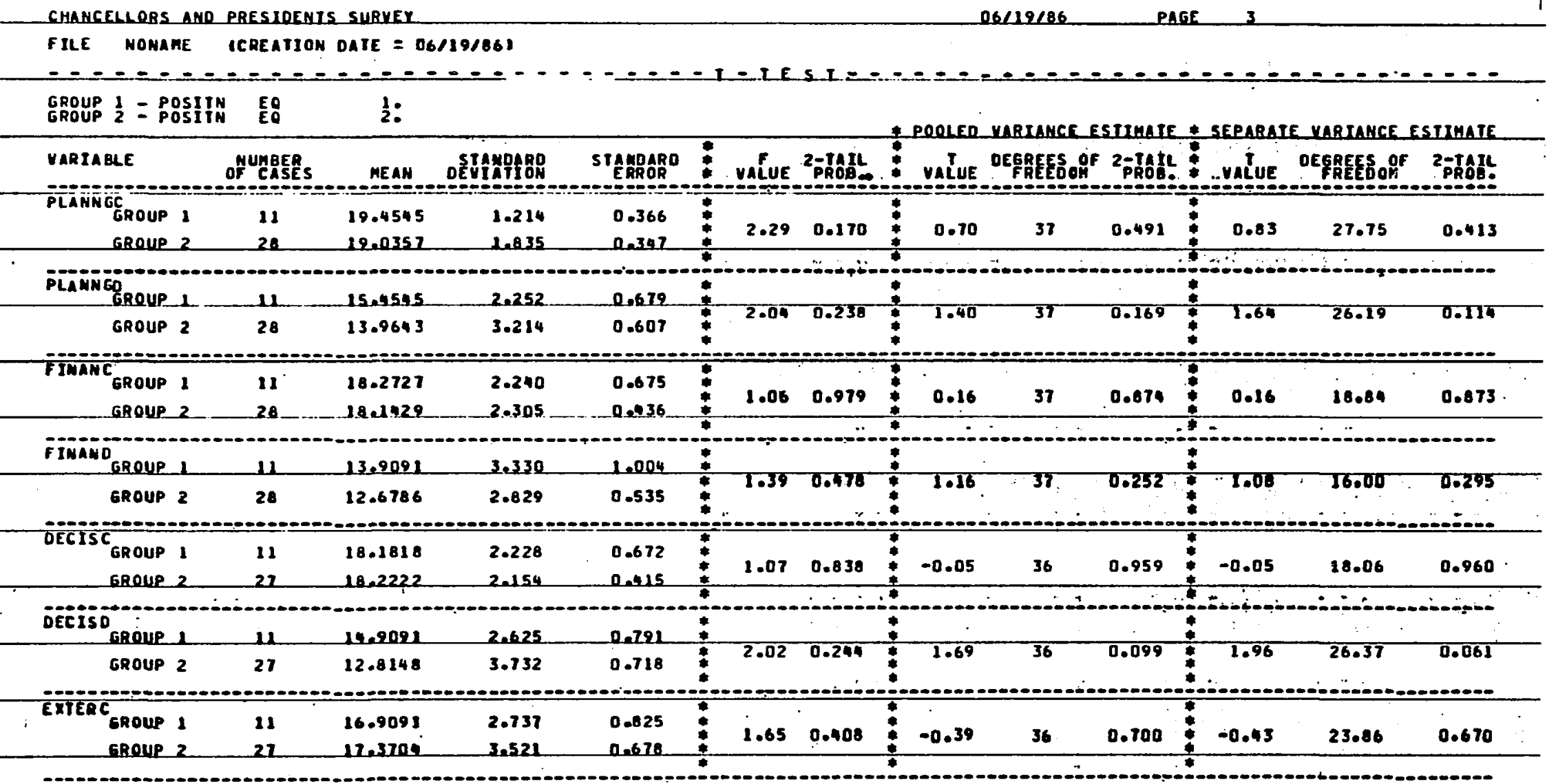


CHAMCELORS AMO PRESIOEMTS SURVEY

06010206

FILE MOMAHE ICREATION OATE $=06 / 19 / 86$

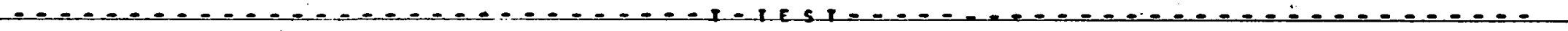

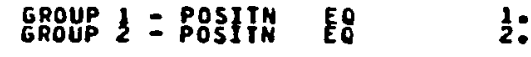

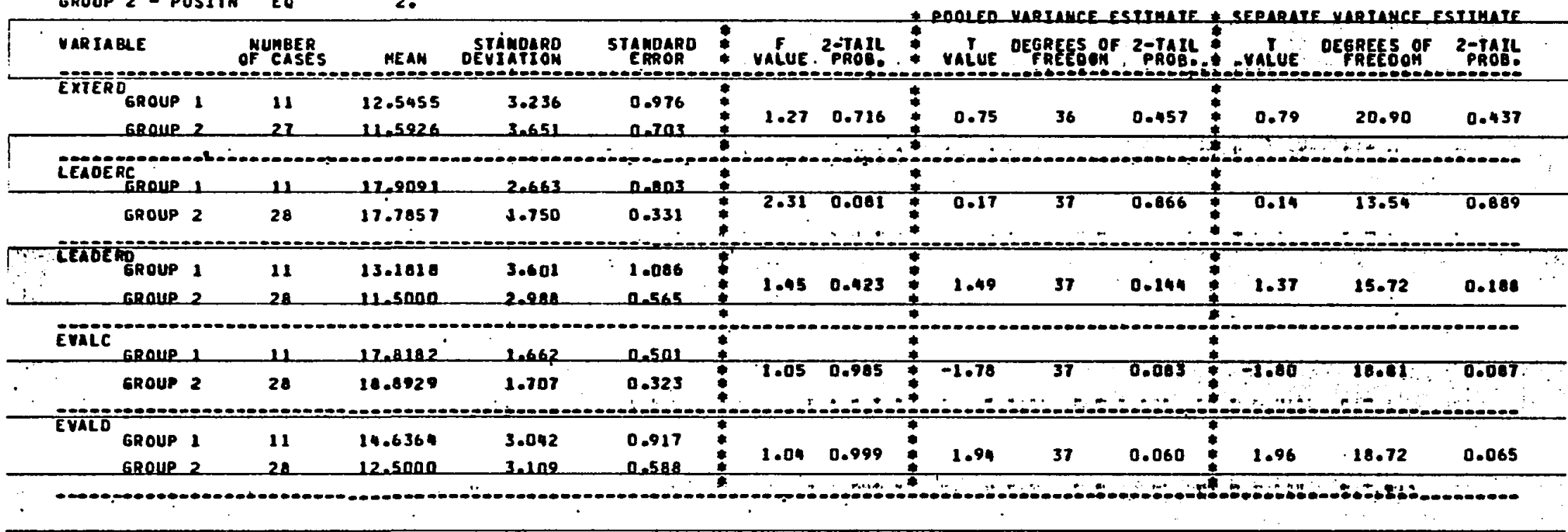


Statewide Differences by Item $\left(\mathrm{x}^{2}\right)$

1 chancellors and presioents surver

$06 / 05 / 86$

PAGE 3

FILE NOAAHE ICREATION DATE $=06 / 05 / 86)$

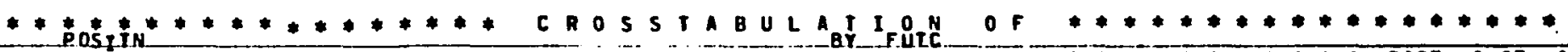

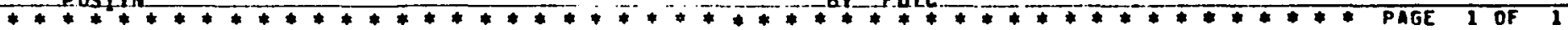
FUTC

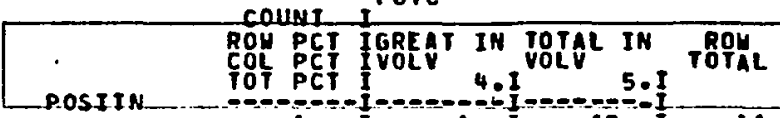

CHANCELLOR

PRESIDENT

2 .

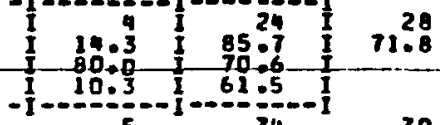

\section{coturn

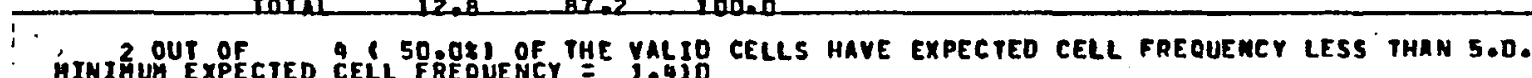

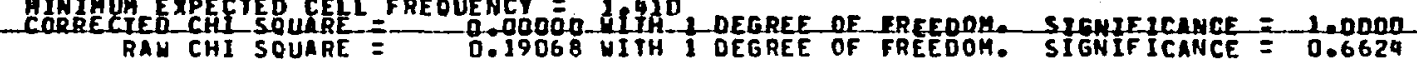

CHANCELLORS AND PRESIDENTS SURVEY

$06 / 05 / 86$ PRGE

FILE hOMAME TCREATION DATE = 06/05/86)

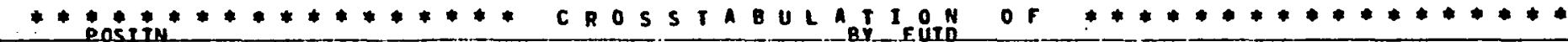

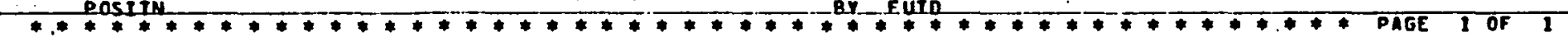
FUTO

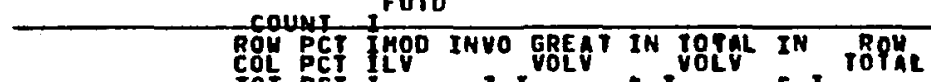

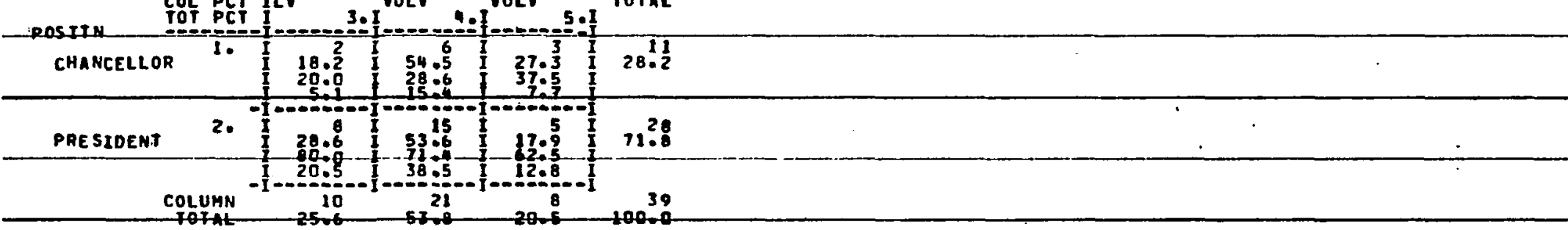

MINIT OUT EXF

CHI SOURE = 


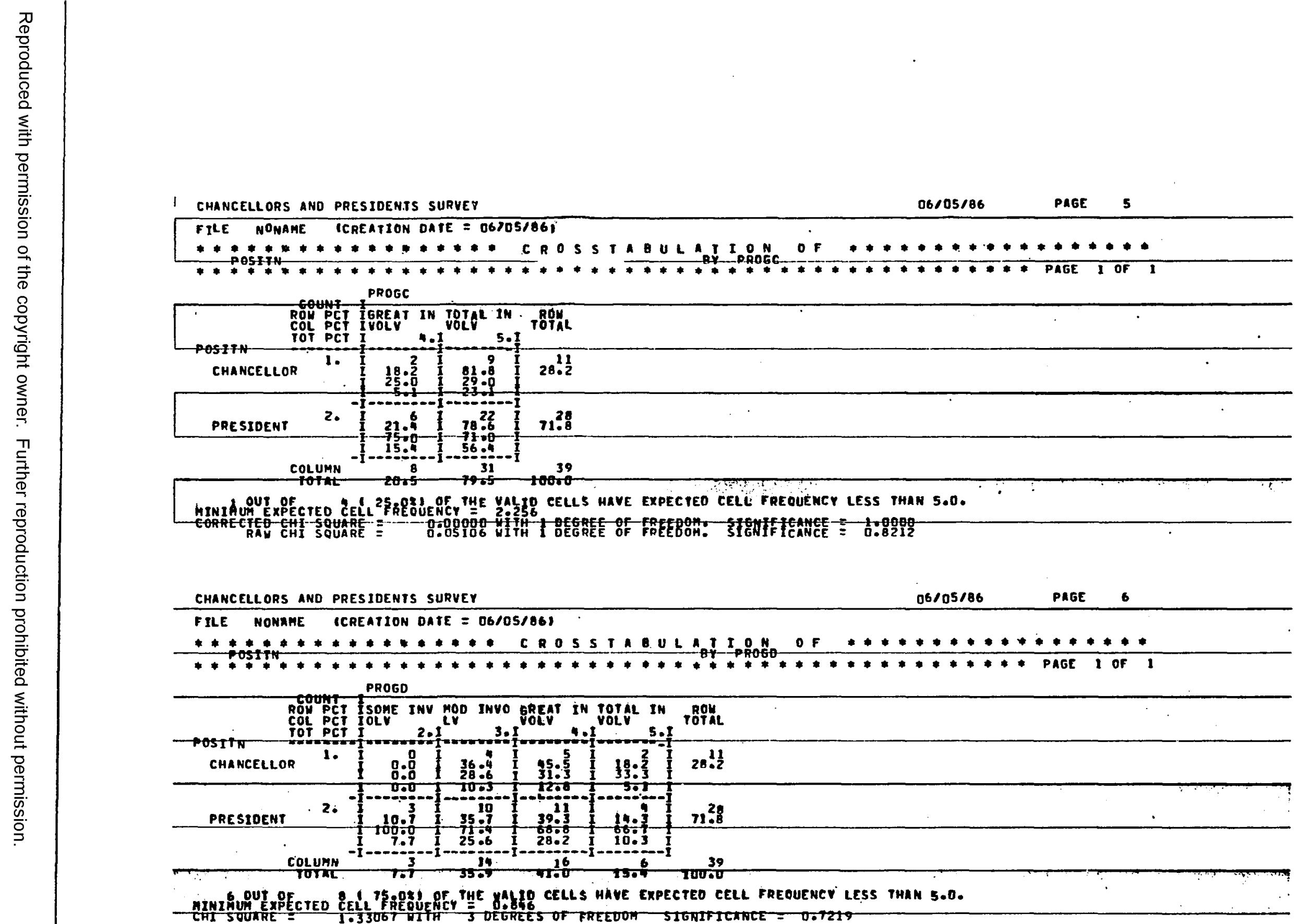


CHANCELL ORS ANO PRESIDENTS SURVEY

$06 / 05 / 86$

PAgE 7

FILE NONAME ICREATION DATE = O6/05/B6)

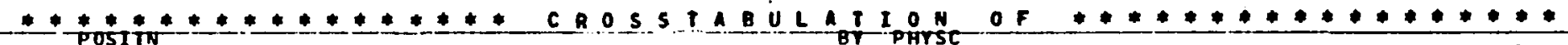

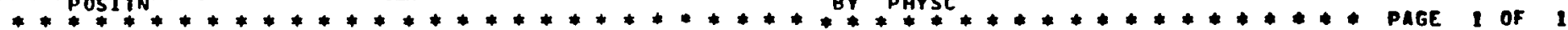

PHYSC

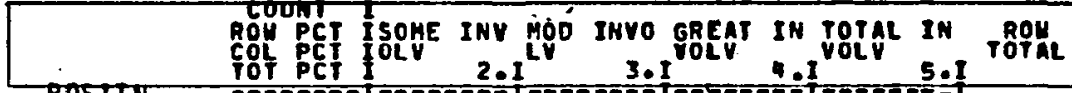

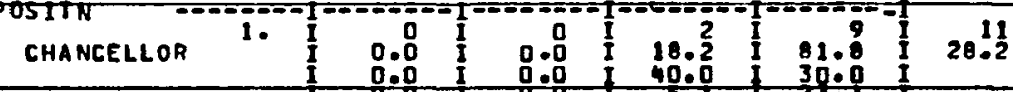

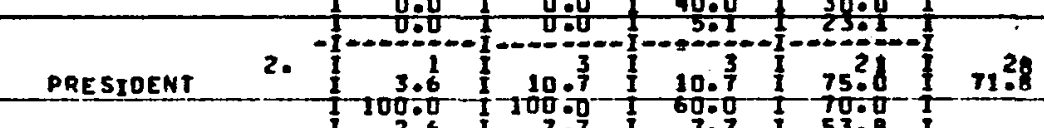

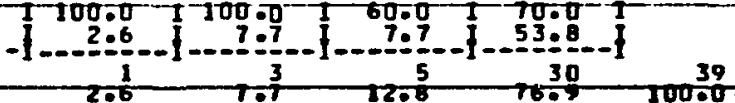

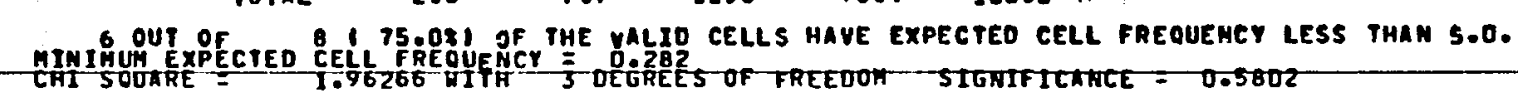

1. CHANCELLORS AND PRESIDENTS SURVEY

06105186

PAGE :

FILE MOMAME ICREATION DATE = 06/05/861

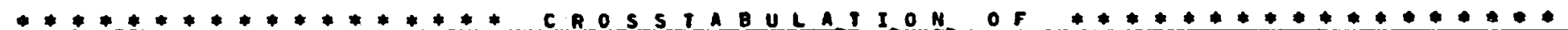

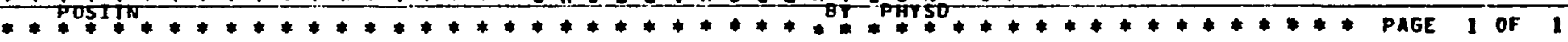

PHYSD

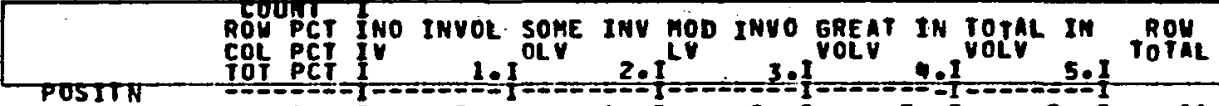

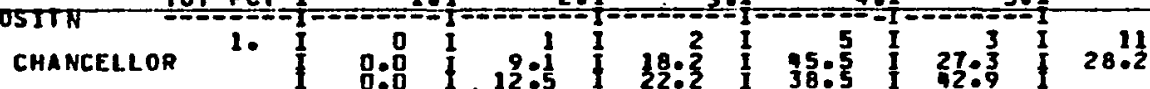

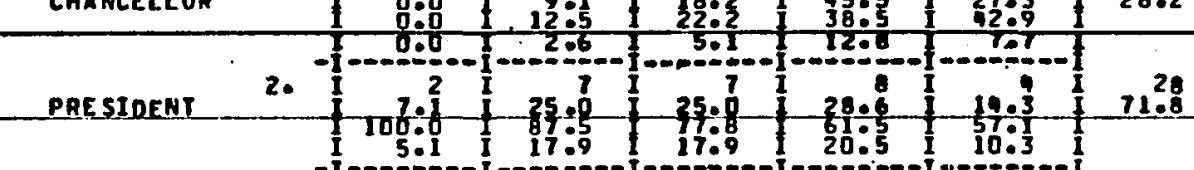

cotumi

5.120 .5

25

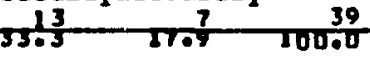

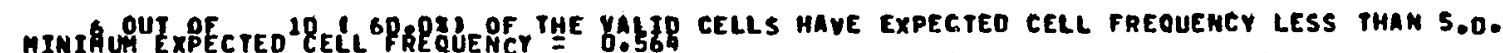

CHI SOUARE 
1 CHANCELLORS ANO PRESIDENTS SURVEY

$06 / 05 / 86$

PAGE,

FILE NOHAME ICREATION OATE $=06 / 05 / 86$ )

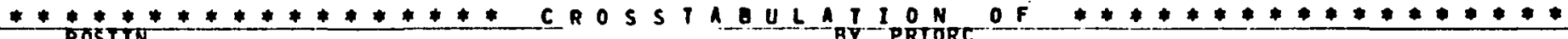

PRIORC

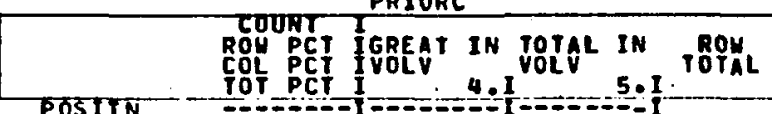

CHANCELLOR I. 10.1 1 90.01028

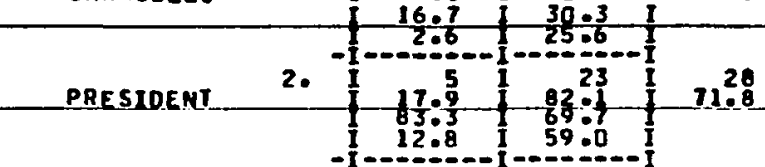

CoLUMA

$15.6^{6}-8.630100 .0$

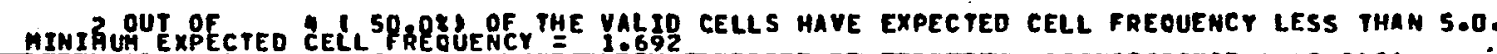

CORPECTEU CHI SODARE

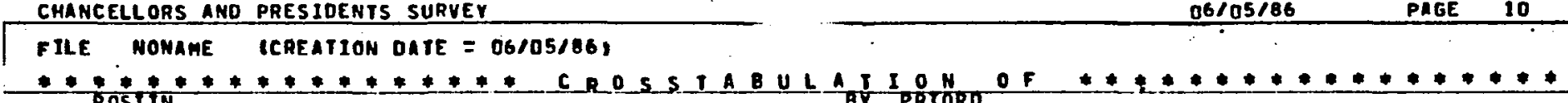

$06 / 05 / 86$

PAGE 10

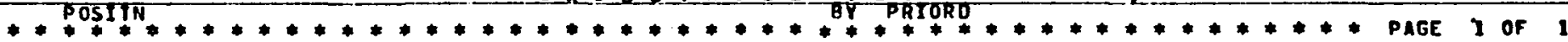

PAIORO

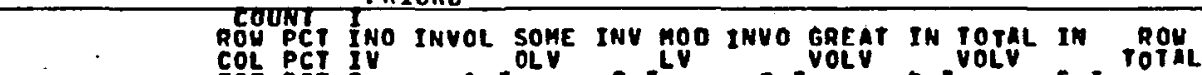

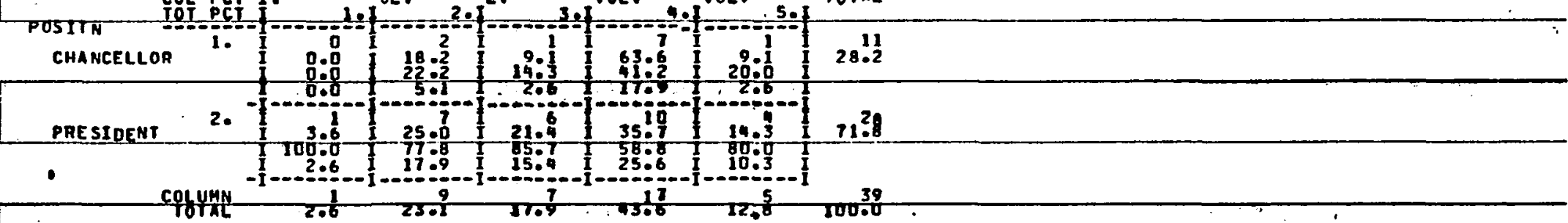

GIM OUT OF $10,70.081$ OF THE YALLO CELLS HAVE EXPECTEO CELL FREOUENCY LESS THAN S.O.

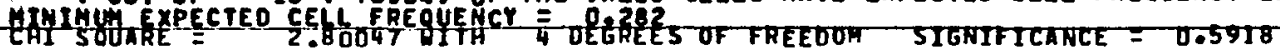


1 CHANCELLORS AND PRESIOENTS SURVEY

$06 / 05 / 86$

PAGE 11

FILE NONAME (CREATION DATE = 06/05/86)

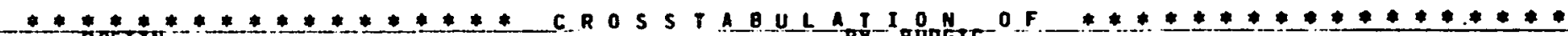

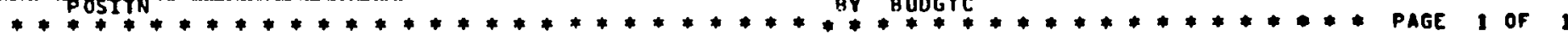

QuDgtc

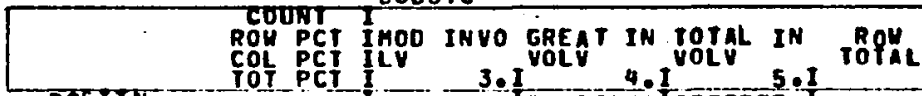

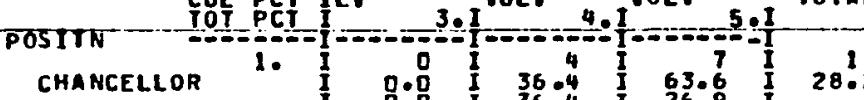

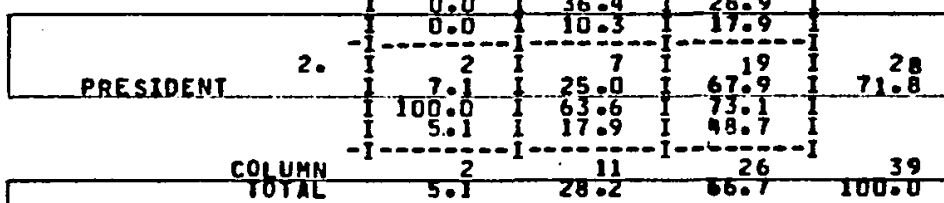

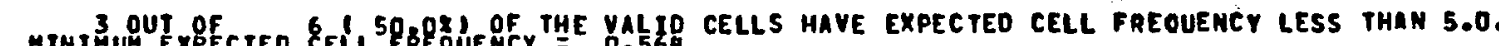

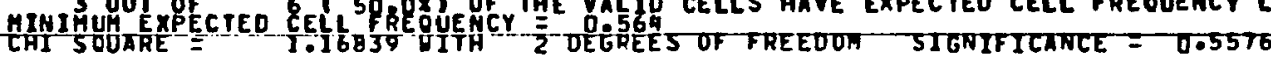

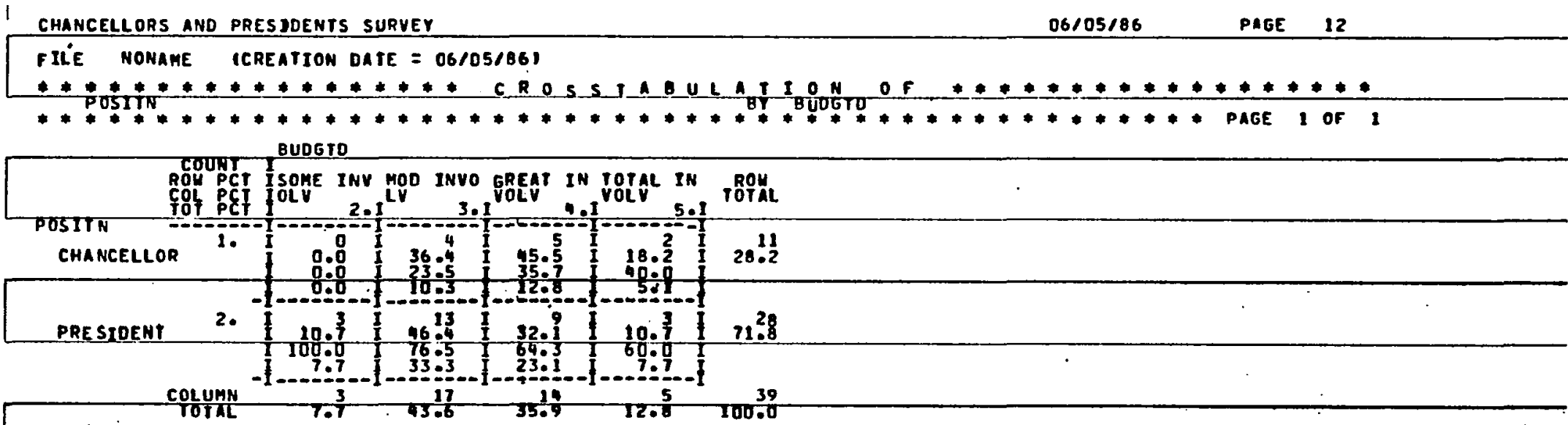

HINI 
CMANCELLLRS AND PRESIOENTS SURUEY

FILE NONAME ICREATION DATE = 06/05/86

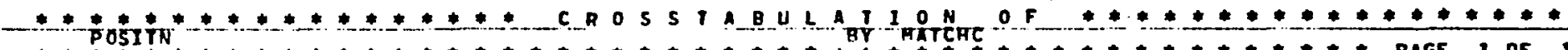

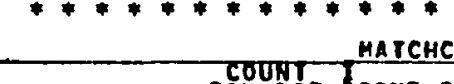

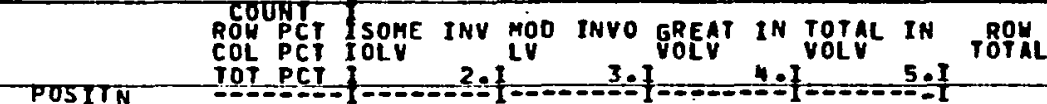

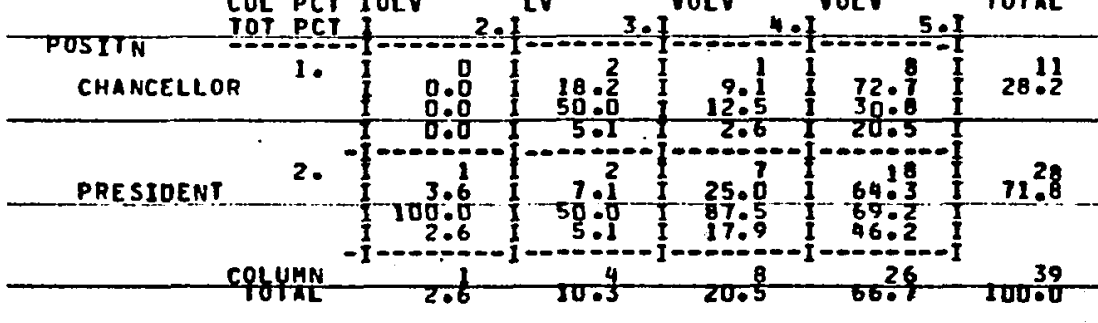

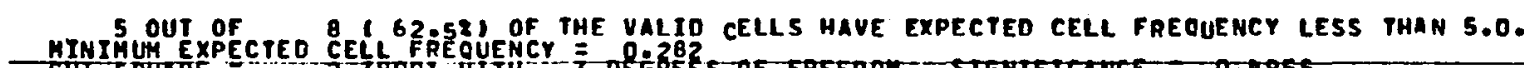

MTNTHUM EXPECTED CELL ERE

CHANCELLORS AND PRESIOENTS SURVEY

$06 / 05 / 86$

PAGE 14

FILE HONAHE ICREATION DATE = 06/05/861

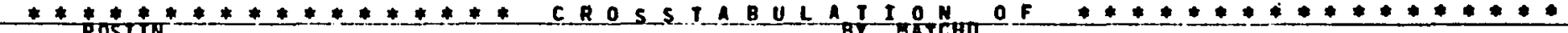

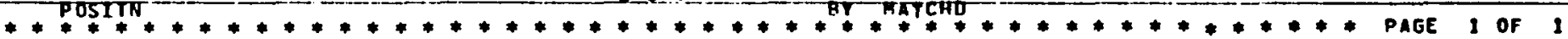
HATCHD

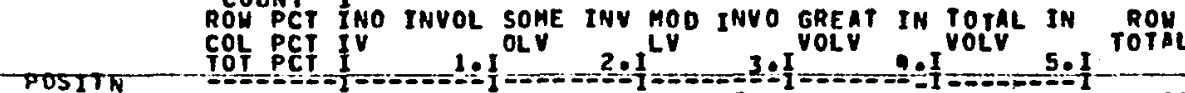

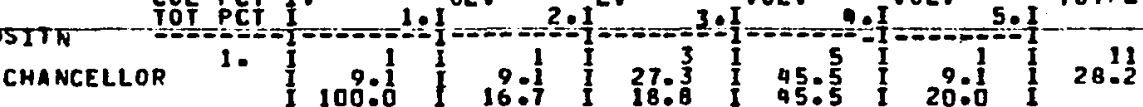

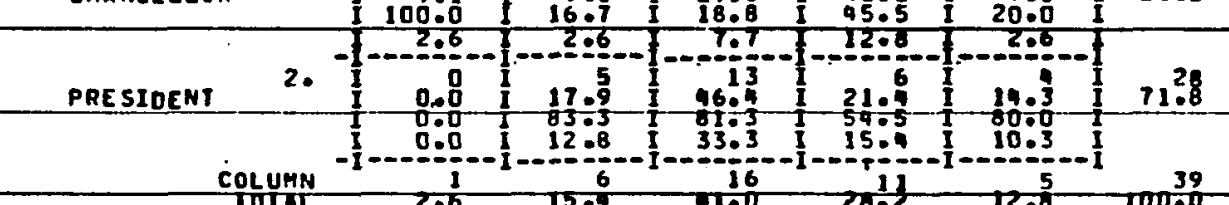

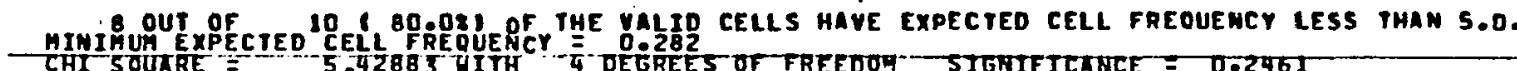


CHANCELLORS ANO PRESIDENTS SURVEY

$06 / 05 / 86$

PAGE

FILE NONAME ICREATION DATE = 06/05/86)

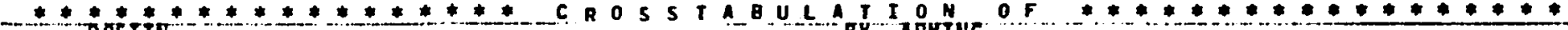

* POSTTN

AOMINC

RON PCT ISOHE INV MOD INYO GREAT IN TOTAL IN TROH TOL

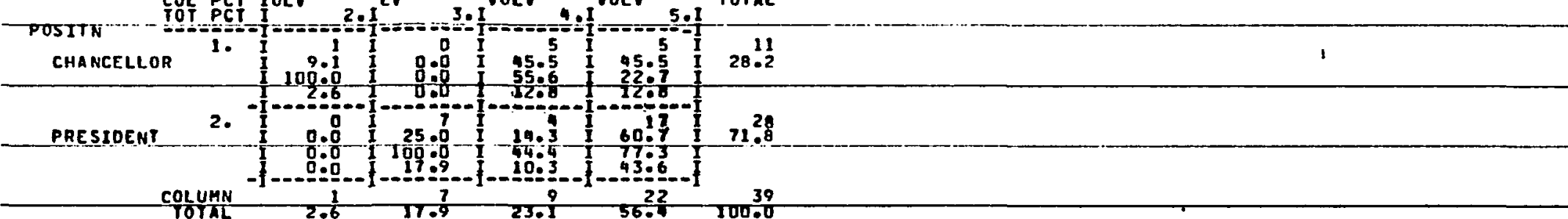

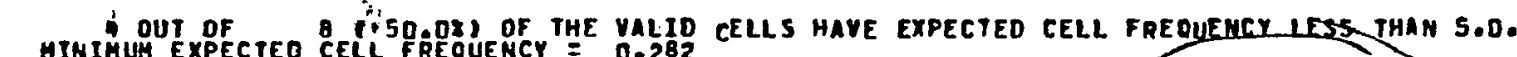

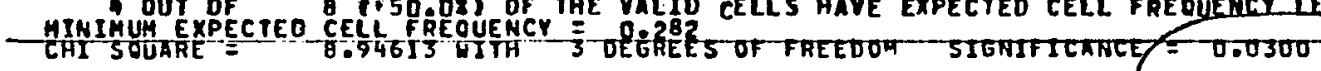

CHANCELLORS AND PRESIDENTS SURVEY

$06 / 05186$

PAGE 16

FILE HOMAME ICREATION OAYE = 06/05/86)

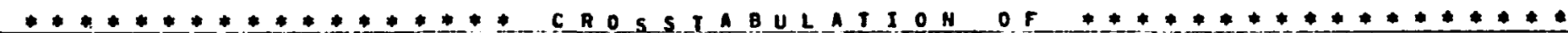

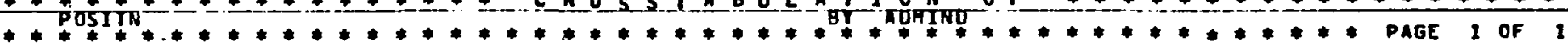

ADMIND

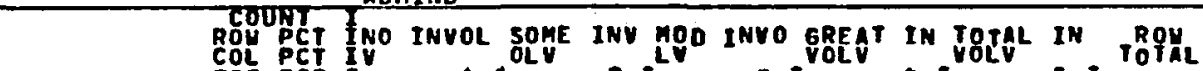

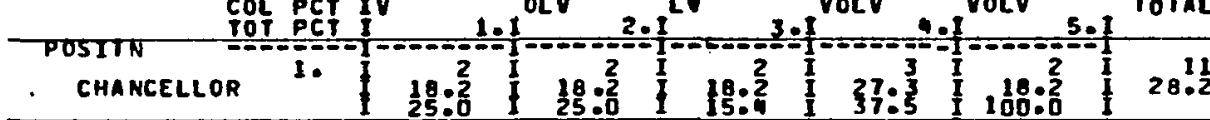

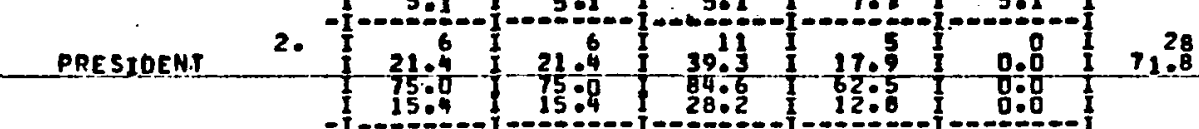

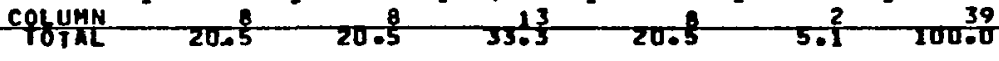

MINI 
CHANCELLORS AND PRES IDENTS SURVEY $06 / 05186$ PAGE $\quad 17$ FILE NONAME ICREATION DATE = 06/05/86)

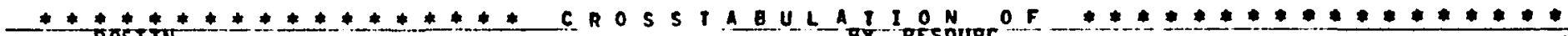

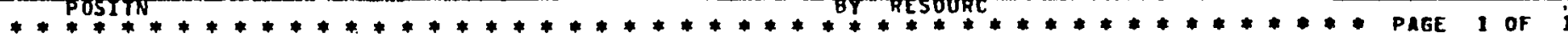

RESOURC

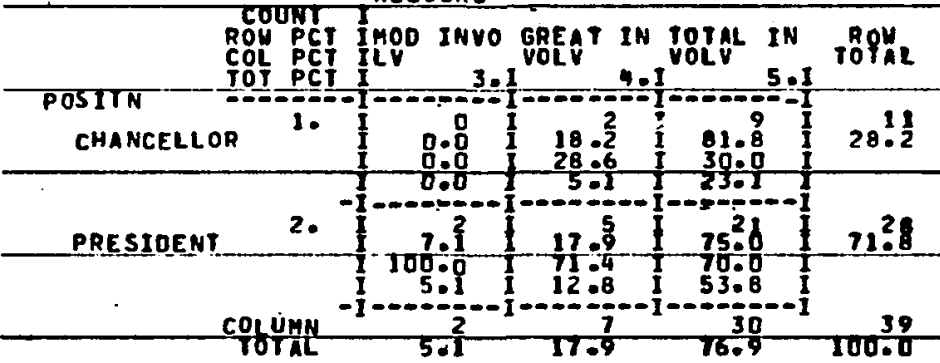

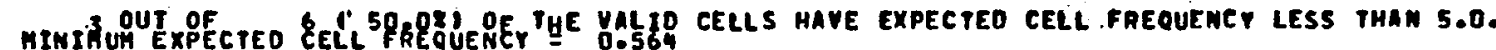

CHI SOUARE =

CHAMCELLORS AND PRESIDENTS SURVEY

$06 / 05 / 86$

PAGE 18

FILE NOMAME (CREATION OATE = 06105/86)

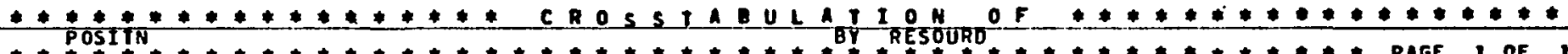

RESOURO

ROH PCI ISOME INV HOD INYO GREAT IN TOTAL IN TROY TL

POSITN
CHANCELLOR

PRE SIOENT

2.

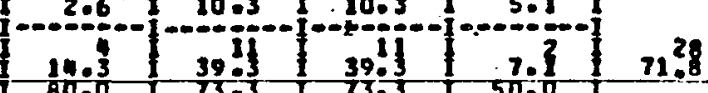

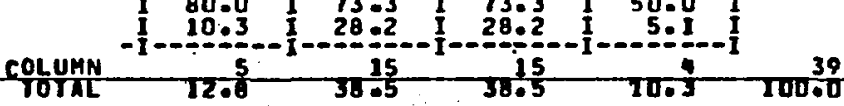

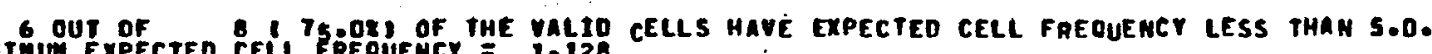

MINIHUH EXPECTED CELL FREQUENCY = 
CHANCELLORS AND PRESIOENTS SURVEY

$06 / 05 / 86$ PAGE 19

FILE NONARE (CREATION DATE = 06/05/86)

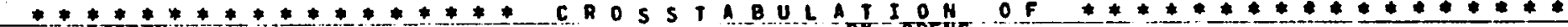

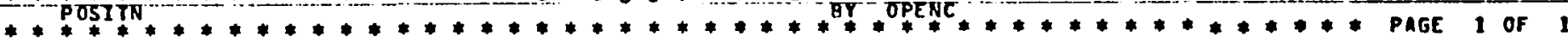

OPENC

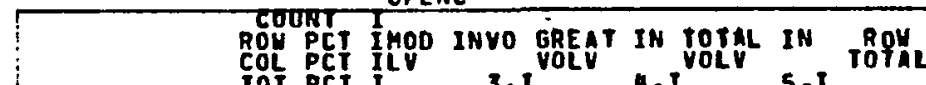

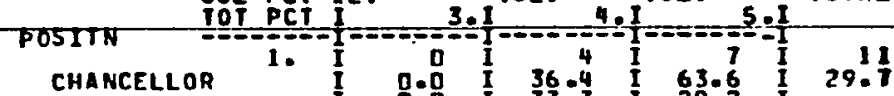

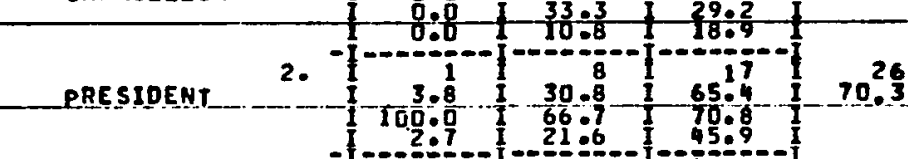

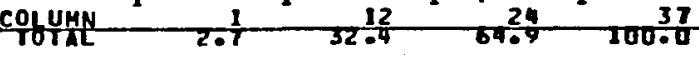

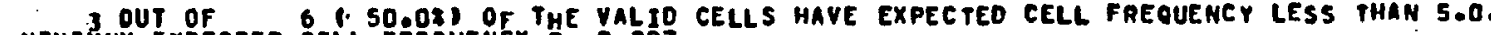

CHI SOURRE =

NUMBER OF MISSING OBSERVATIONS $=2$

CHANCELLQRS AND PRESIOENTS SURVEY

$06 / 05 / 86$

PAGE 20

FILE NONAME ICREATION OATE = 06/05/86)

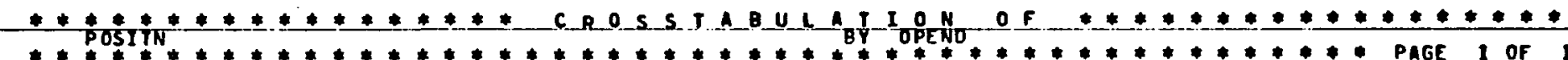

OPEND

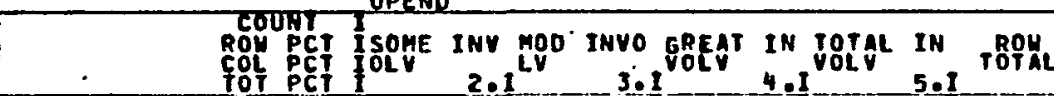

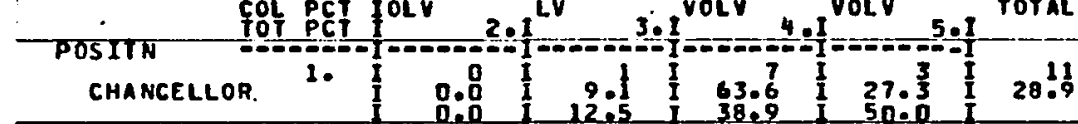

PRESIDENT

2.

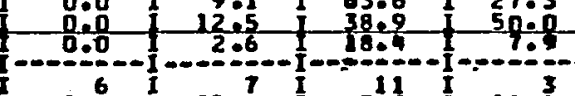

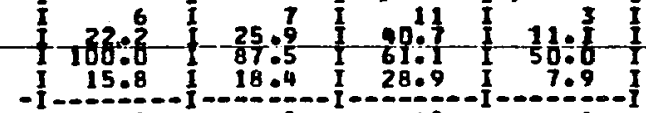

CoLUHA

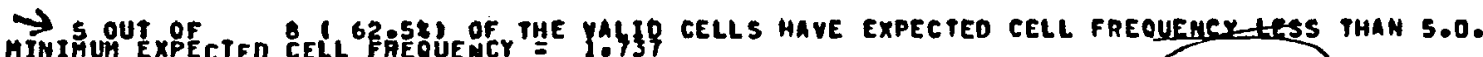

MINIMUN EXPECTEO CELL FHEOUENCY

NUHBER OF MISSING OBSERVATIONS = 
CHANCELLORS NDO PRESIDENTS SURVEY

$06 / 05 / 06$

PAGE 21

FILE NONAHE (CREATION DATE $=06 / 05 / 86$ )

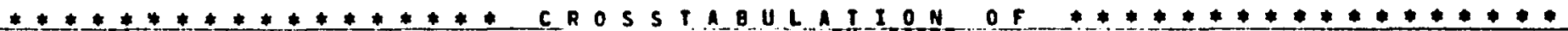

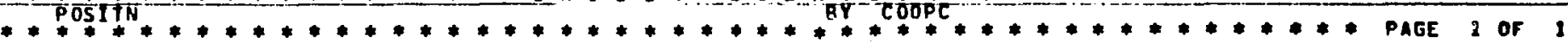

COOPC

RON PCT IHOO INVO GREAT IN POTAL IN ROY TOL
COL PCT ILY TOTAL

POSTIN

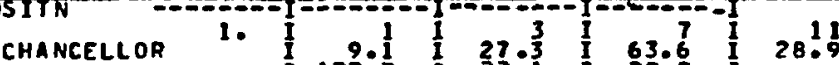

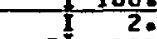

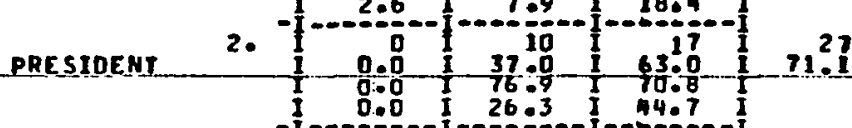

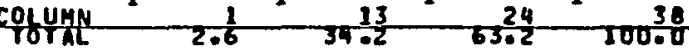

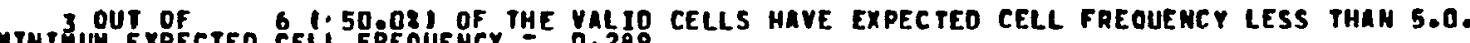

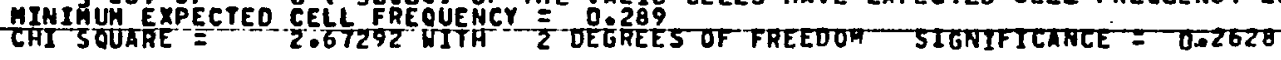

NUMBER OF MISSING OBSERYATIONS =

CHANCELLORS AND PRESIDENTS SURVEY

FILE NOHARE ICREATION OATE $=06 / 05 / 861$

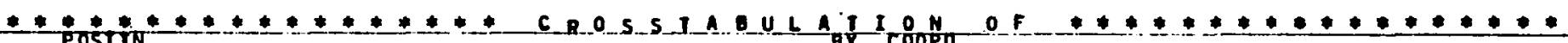

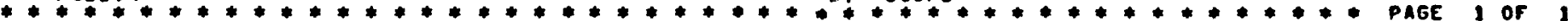

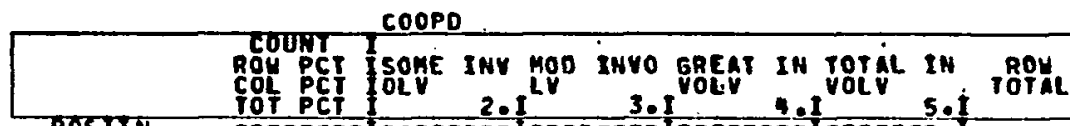

CHANCELLOR

PRESIOENT

2.

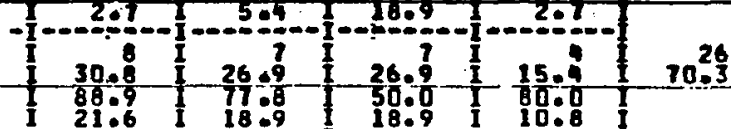

COLUHA

$\rightarrow$ OOU OF

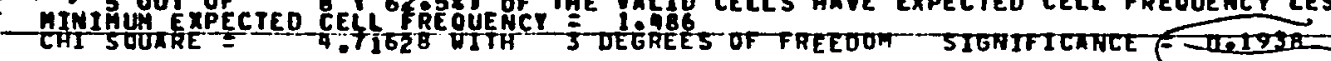

NUMBER OF MISSING OBSERVATIONS = 
I CHANCELLORS AND PRESIDENTS SURYEY

$06 / 05186$

PA6E 23

FILE NONAME ICREATION DATE $=06 / 05 / 861$

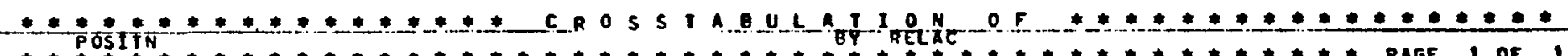

$* * * * * * * * * * * *$

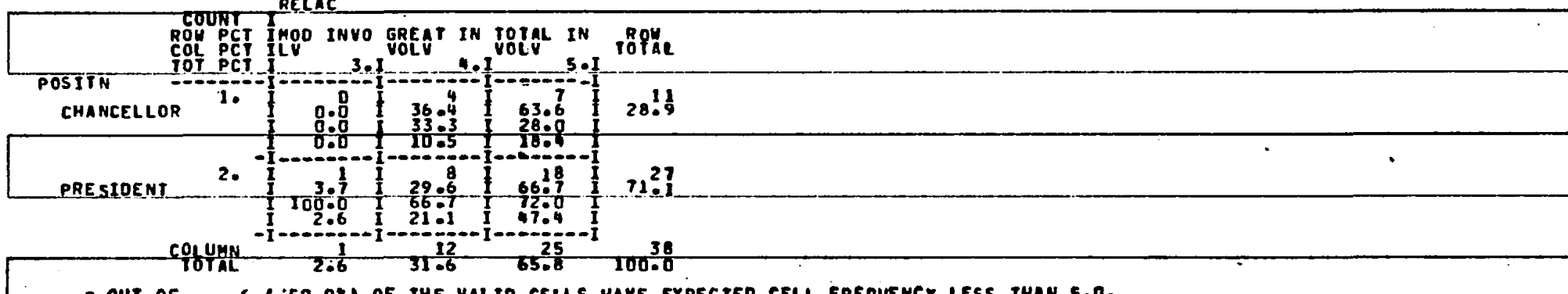

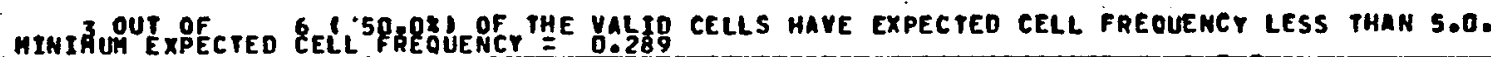

CHISOUAFE

MUMBER OF MISSING OBSERYATIONS =

CHANCELLORS AND PRESIOENTS SURVEY

$06 / 05 / 86$

PAGE - 24

FILE NONAME (CAEATION DATE $=06 / 05 / 86$,

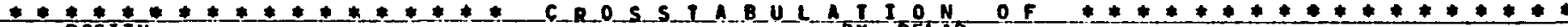

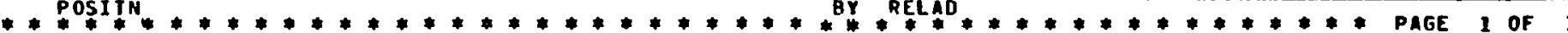

RELAD

ROHUTCY INO INVOL SOME INV MOD INVO GREAT IN TOTEL IN ROY TOL

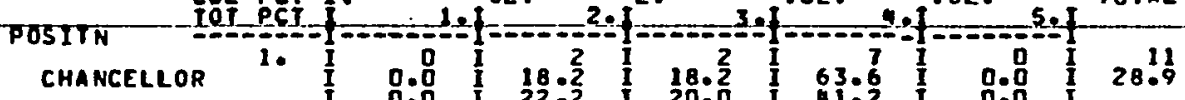

CHANCELLOR

PRESIDENT

2.

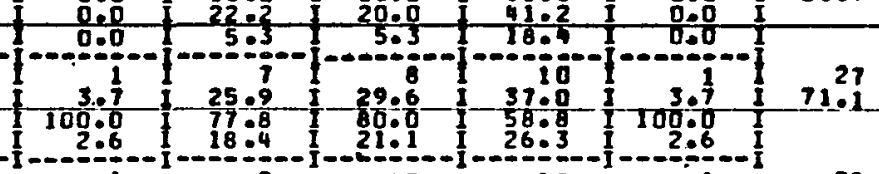

ColunN

$2.6-23.9$

26.9

$\frac{13}{2.6^{2}}+10000$

MINITUN OUT OF

NUMBER OF MISSING OBSERVATIONS = 
CHANCELLRS ANO PRESIRENIS SURYEY

$0610518_{6}$

PAGE 25

FILE NONAME ICREATION DATE = D6/05/86)

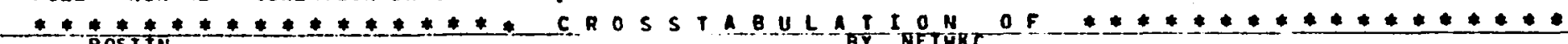

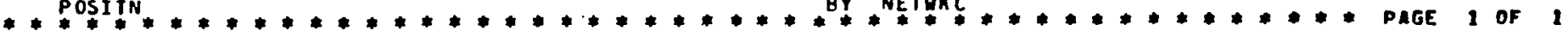

\begin{tabular}{|c|c|c|c|}
\hline $\begin{array}{r}\mathrm{R} \\
\mathrm{C} \\
\mathrm{C}\end{array}$ & 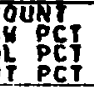 & $\begin{array}{c}\text { MOO INYO GAEAT IN TOTAL IN } \\
3.1\end{array}$ & TofHL \\
\hline $\begin{array}{l}\text { POSITN } \\
\text { CHANCELLOR }\end{array}$ & 10 & $9.1 \quad 145.5$ & 28.9 \\
\hline & 2. & & $71^{2}$ \\
\hline
\end{tabular}

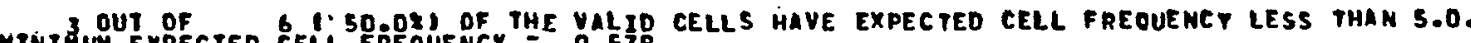

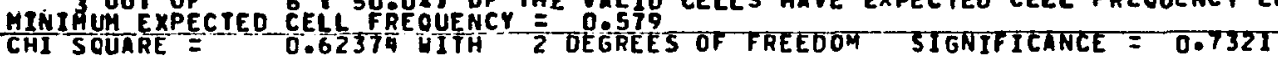

NUHBER OF MISSING OBSERVATIONS =

CHAMCELLORS ANO PRESIDENTS SURYEY

$06 / 05 / 86$

PRGE 26

FILE NOHAHE TCREATION DATE = 06/05/86)

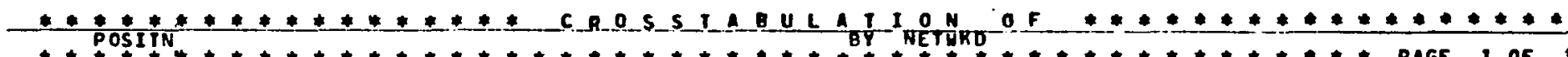

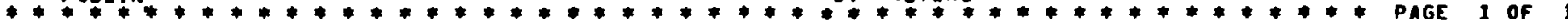

METUKO

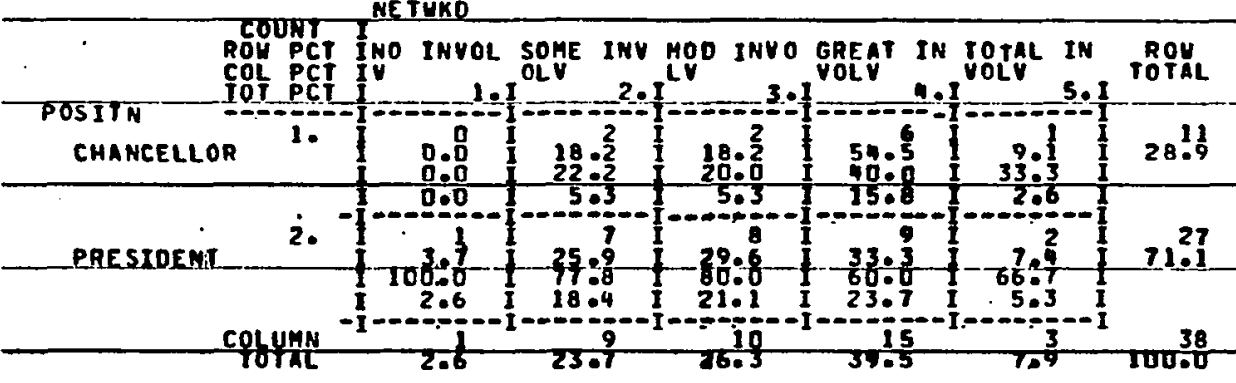

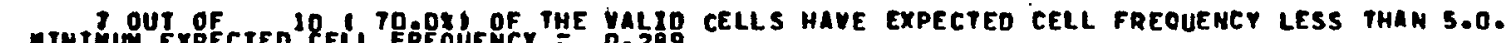

MIHITUN EXPECIEO CELL FREOUENCY

NUMBER OF HISSING OBSERYATIONS = 
CHANCELL ORS AND PRESIDENTS SURVEY

$06 / 05 / 86$

PAGE 2T

FILE NONAME ICREATION DATE $=06 / 05 / 861$

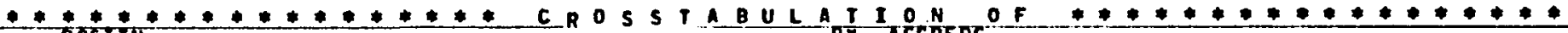

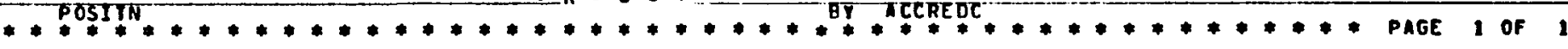
ACCREDC

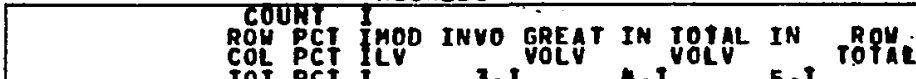

POSITN TOI PCI

CHANCELLOR

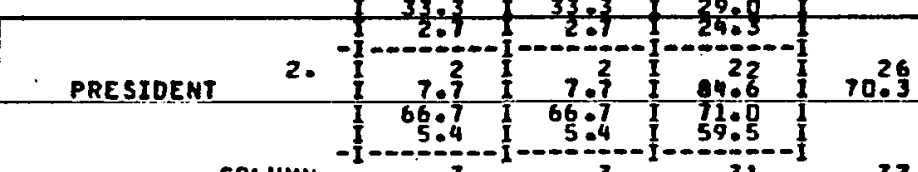

COLUMA

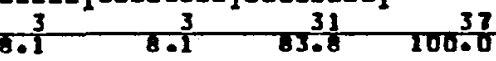

DOUT OF $6(66.78)$ OF THE YALIO CELLS HAVE EXPECTEO CELL FREQUENCY LESS THan S.0.

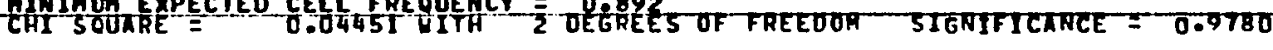

NUMBER OF HISSING OBSERVATIONS =

CHAMCELLORS AND PRESIOENIS SURYEY

$06 / 05 / 86$

PAGE 28

FILE MONAME ICREATION DATE = 06/05/88

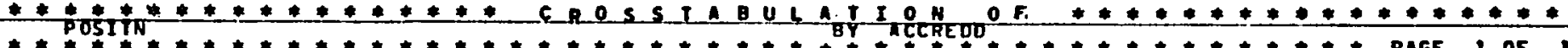

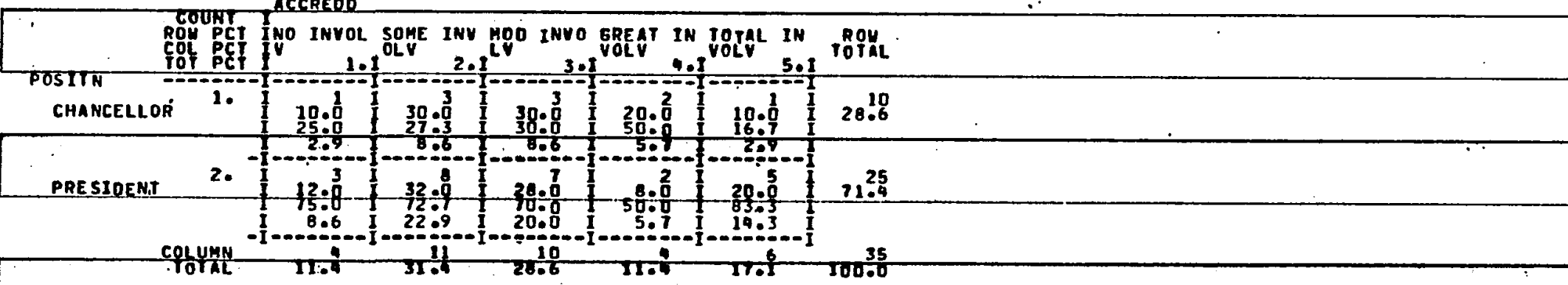

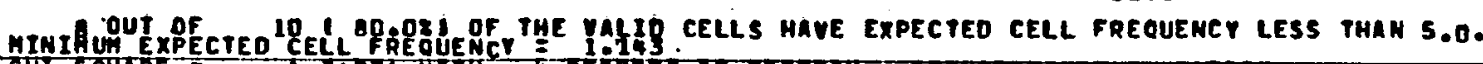

CHI SOOKRE

NUMBER OF MISSING OBSERVATIONS = 
CHANCELL ORS AND PRESTOENTS SURUEY

$06 / 05 / 86$

PAGE 29

FILE NONAME ICREATION DATE $=06 / 05 / 96$,

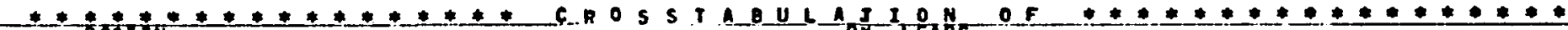

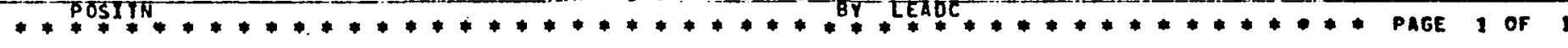

LEAOC

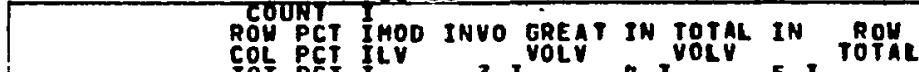

POSIIN

PRESIDENT

2. $\frac{-1}{1}$

cofunit

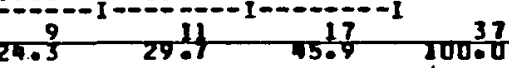

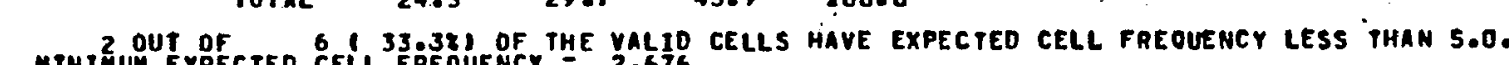

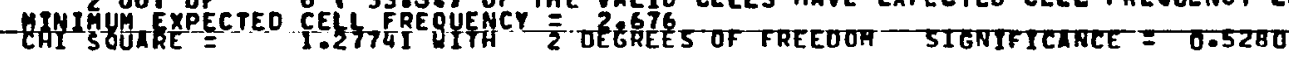

NUMBER OF MISSING OBSERVATIONS =

CHANCELLORS AND PRESIDENTS SURVEY

FILE NOMAHE ICREATION DATE = 06/05/B6)

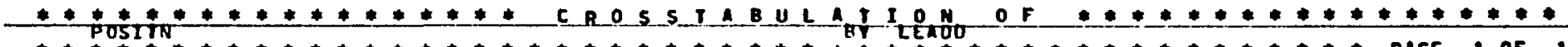

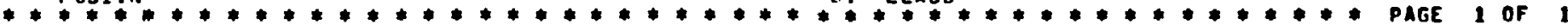

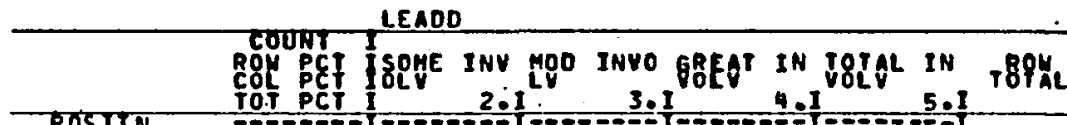

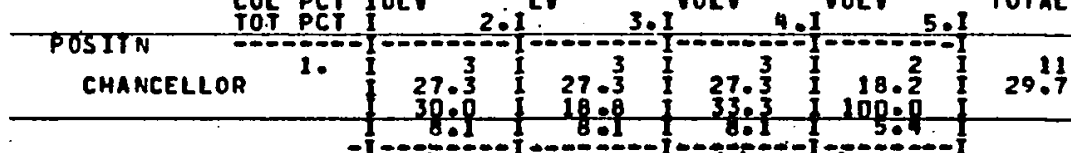

PRESIDEHT

2.

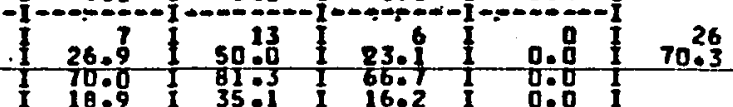

COLUAH

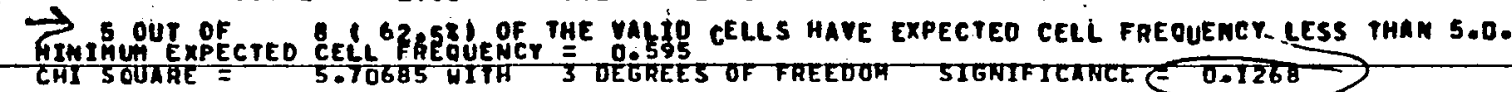

NUMBER OF MISSING OBSERVATIONS = 


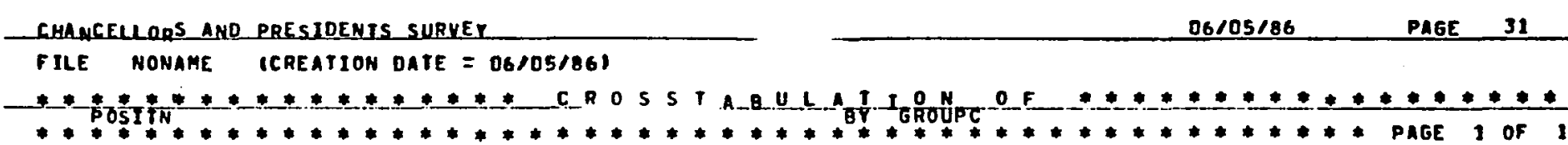

GROUPC

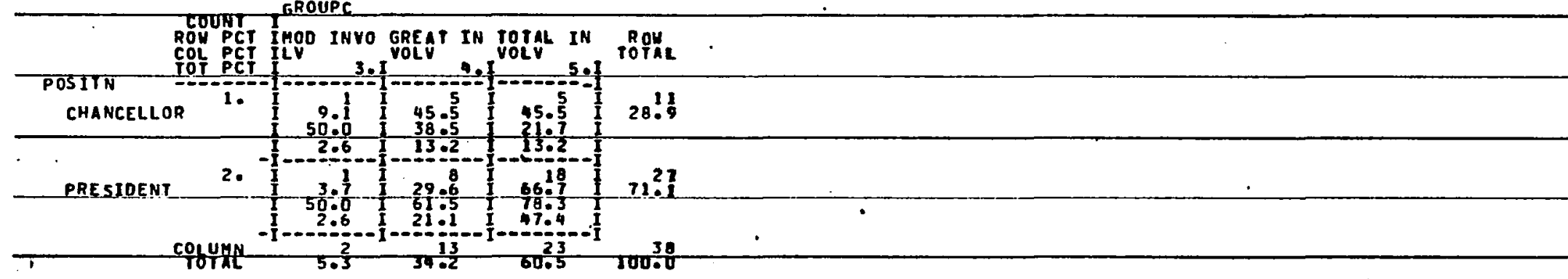

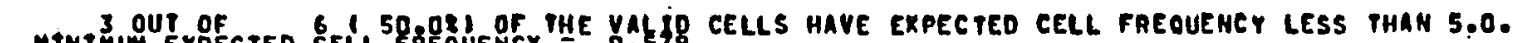

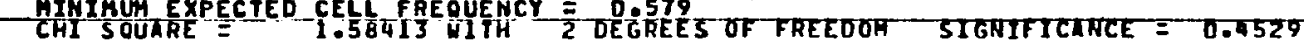

HUHBER OF MISSING OBSERVATIONS =

CHAMCELL ORS ANO PRESIOENTS SURVEY

$06 / 05 / 86$

PAGE 32

FILE NOMAME ICREATION DATE = 06/05/86I

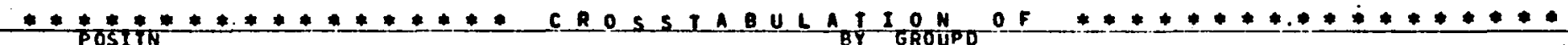

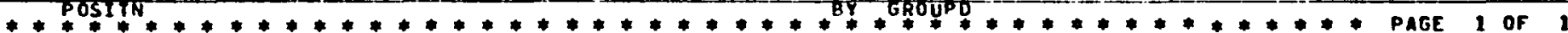

GROUPD

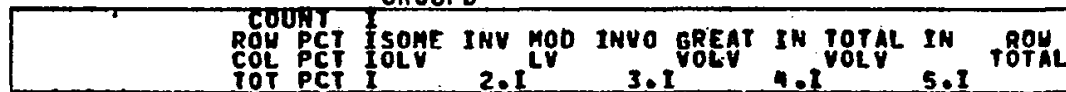

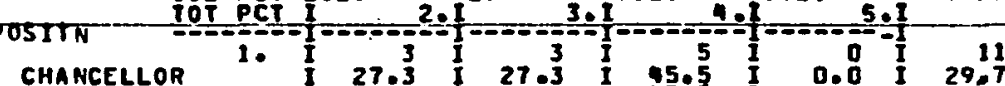

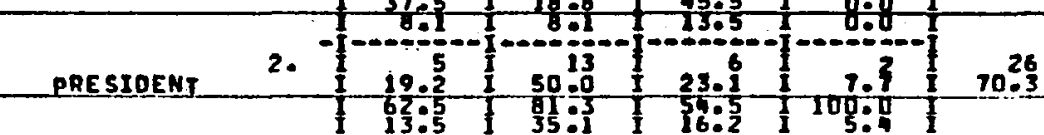

COLUHN

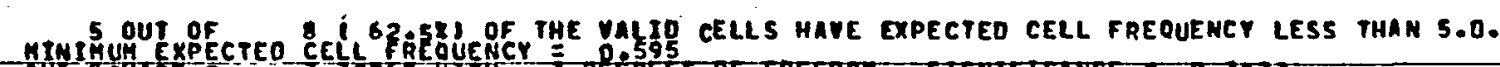

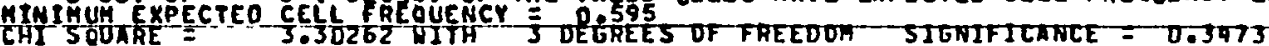

NUMBER OF MISSING OBSERVATIONS = 
CHANCELLORS AND PRESIDENIS SURYEX

$06 / 05 / 86$

PAGE 33

FILE NONAME TCREATION DATE = O6/OS/B6

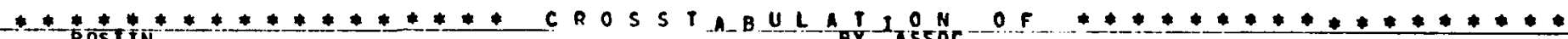

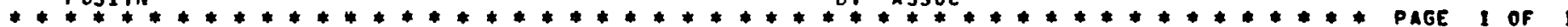

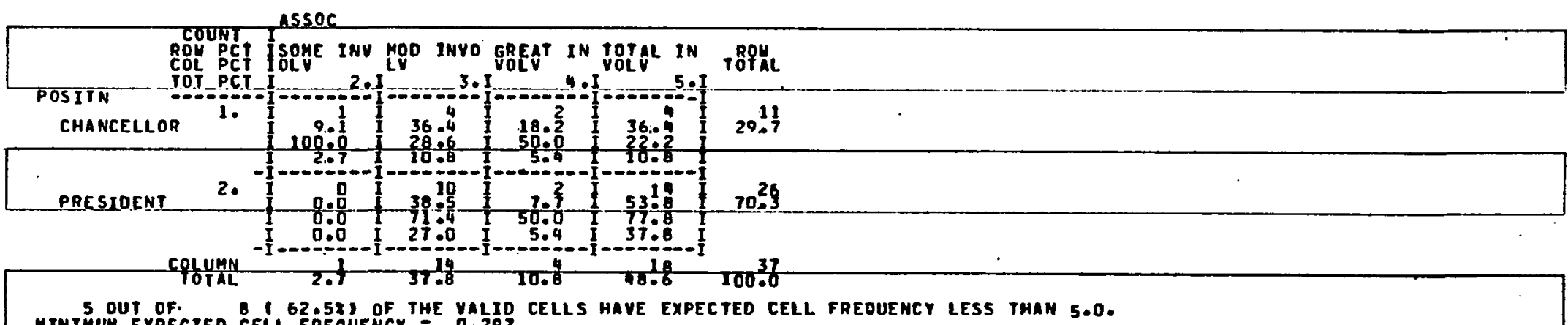

S OUT OF.

CHI SOUARE

NUMBER OF MISSING OBSERVATIONS = 2

CHANCELLORS AND PRESIDENTS SURVEY

$06 / 05 / 86$

PAGE 34

FILE NONAME ICREATION DATE = 06/05/86)

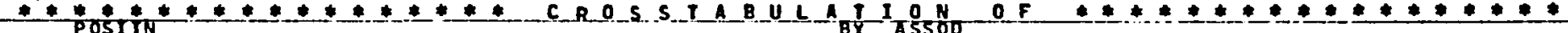

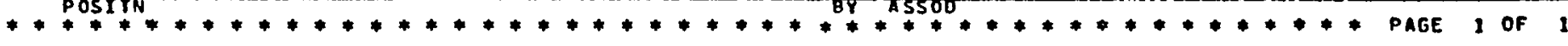

15500

ROH PCT INO INVOL SOME INV MOO INUO GREAT IN TOTAL IN TROY

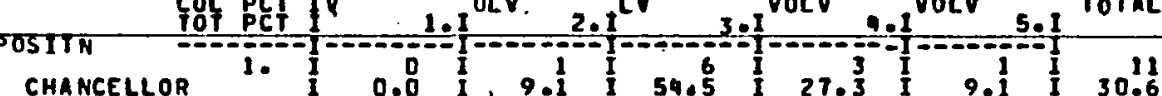

PRESIDENT

2.

COLUAN

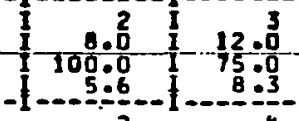

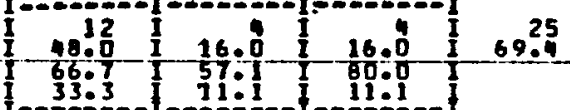

$5.6-11.1 \quad 50.0$

19.4013 .90000

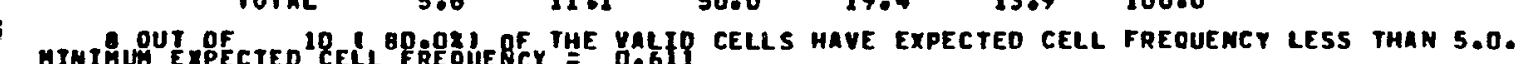

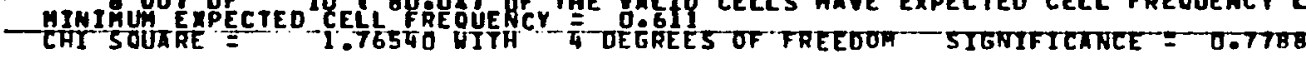

NUMBER OF MISSING OBSERVATIONS = 3 
CHANCELLORS AND PRESIOENTS SURVEY

$06 / 05 / 86$

PAGE 35

FILE NONAME ICREATION DATE = 06/05/86)

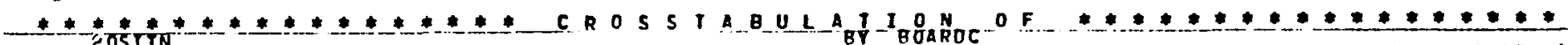

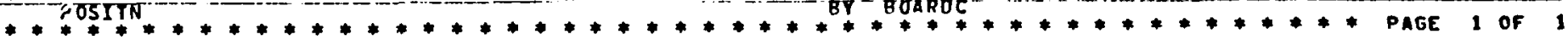

BQAROC

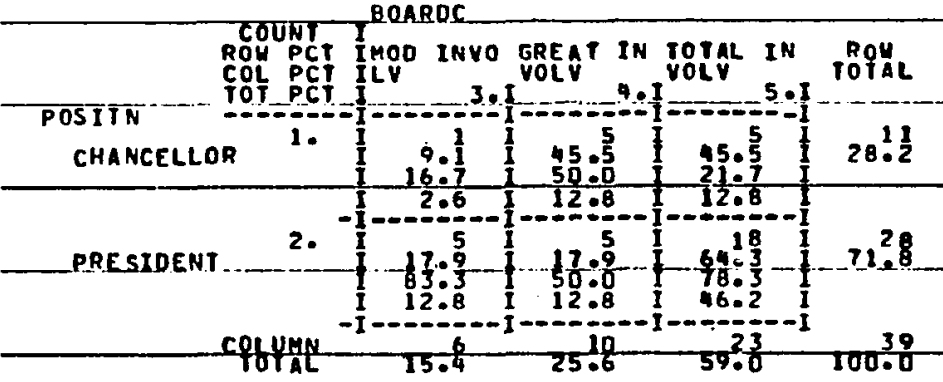

HT OUT OF 6 50.08 OF THE YALIO CELLS HAVE EXPECTED CELL FREOUENCY LESS THAN 5.0.

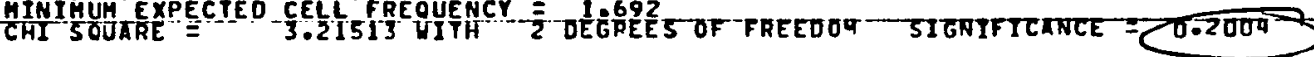

CHANCELLORS AND PRESIOENTS SURVEY

$06 / 05 / 86$

PRGE 36

FILE NONAME ICREATION OATE = 06/05/861

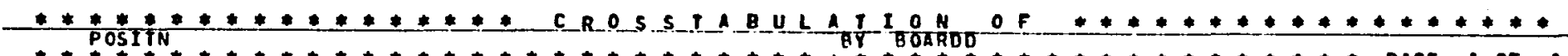

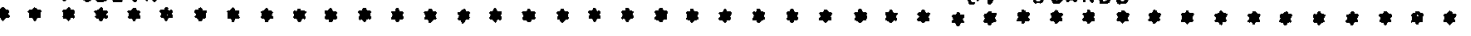

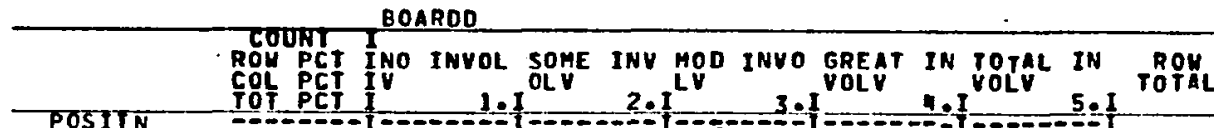

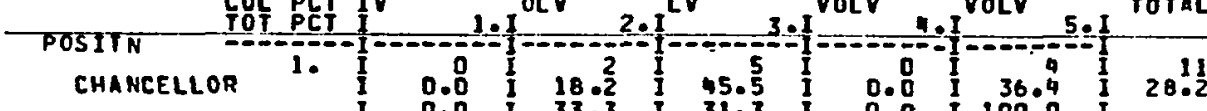

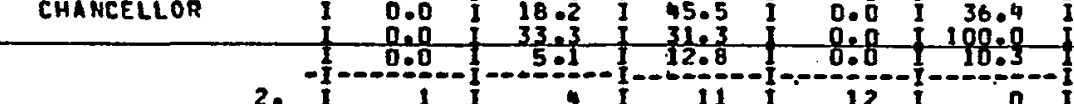

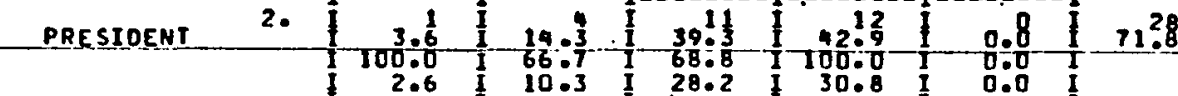

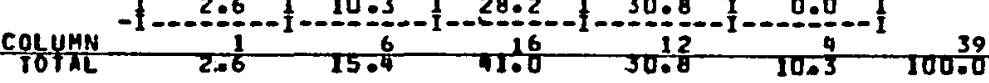

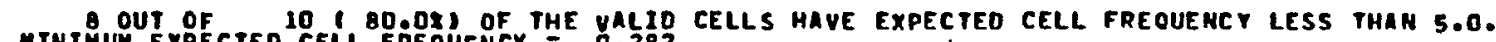


CHANCELLORS ANO PRESIDENTS SURVEY

$06 / 05 / 86$

PAGE $T^{7}$

FILE NONAME ICREATION DATE = 06/05/86)

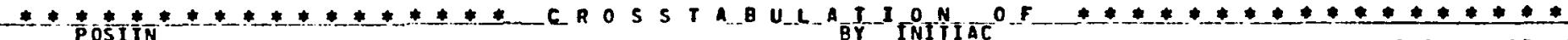

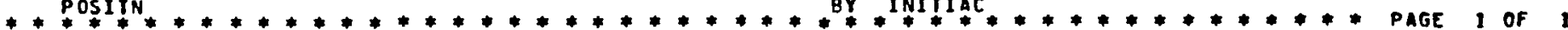

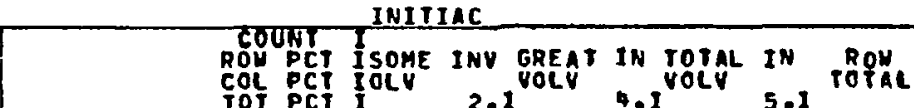

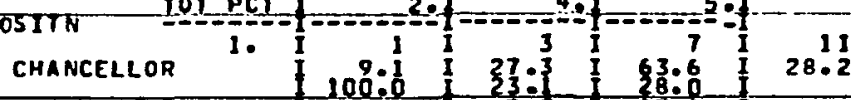

PRESIOENT

2.

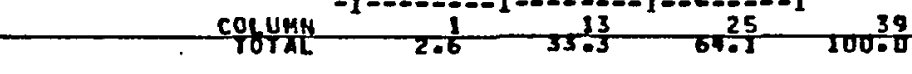

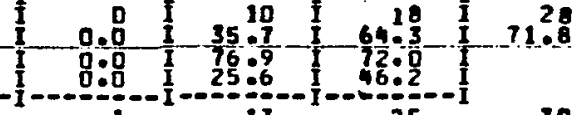

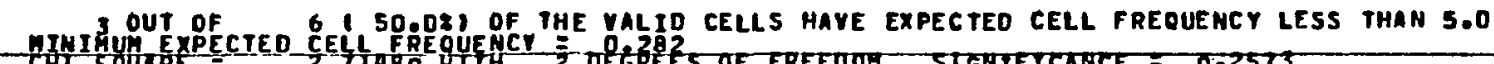

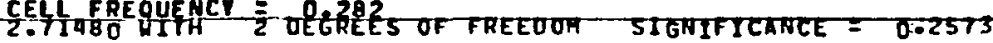

CHAMCELLORS AND PRESIDENTS SURVEY

$06 / 05 / 86$

PAGE 38

FILE NOMAME (CREATION DATE = O6/05/86)

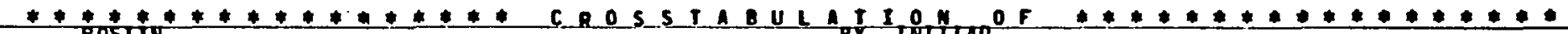

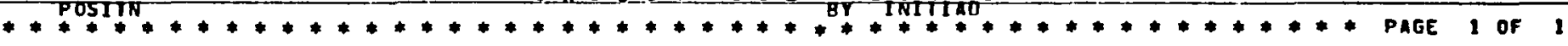

INITIAR

ROUW PCT INO INVOL SOME INV HOD INVO GREAT IN TOTAL IN TROY

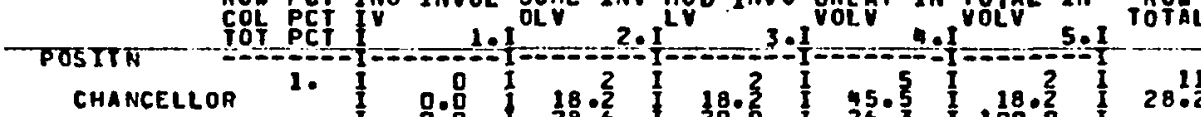

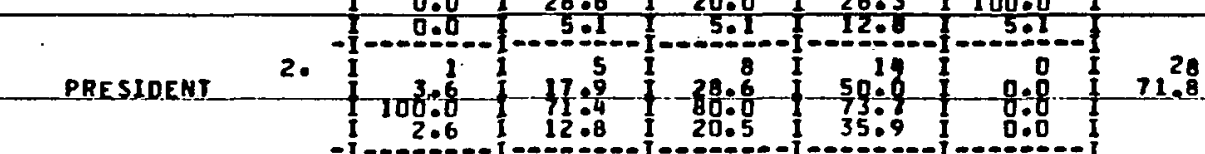

COLUMN

$\frac{1}{2.6} 17.9-25.6$

$5.1 \quad 300.0$

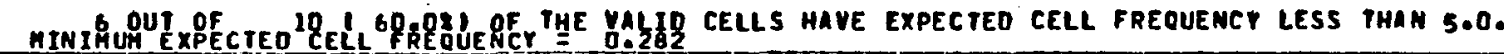


1 CHANCELLORS AND PRESIOENTS SURVEY

$06 / 05 / 86$ PAGE 39

FILE NONAME ICREATION DATE $=06 / 05 / 861$

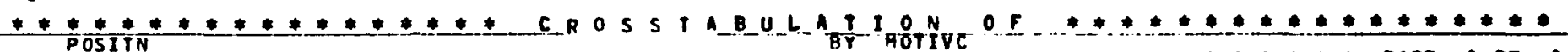

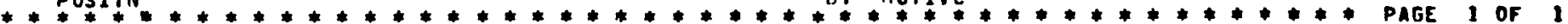

\begin{tabular}{|c|c|c|c|}
\hline 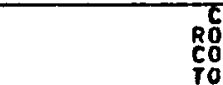 & 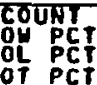 & IGREAT IN TOIAL IN & TOPHAL \\
\hline $\begin{array}{l}\text { POSITN } \\
\text { CHANCELLOR }\end{array}$ & 1 & $\begin{array}{r}1 \\
1 \\
1 \\
15.6 \\
25.9 \\
\end{array}$ & $28.1 \frac{1}{2}$ \\
\hline PRESTDENT & 2. & $77^{20}: 1-$ & $\begin{aligned} 21.8 \\
\end{aligned}$ \\
\hline
\end{tabular}

HIMIAUUY OPOE

CORRECTEO CHY SODARE

CHANCELLORS AND PRESIDENTS SURYEY

$06 / 05 / 86$

PAGE

FILE HONAME ICREATION OATE = 06/05/86)

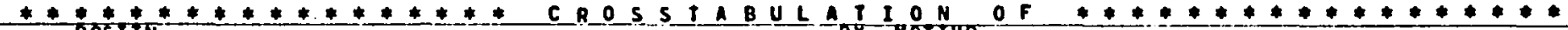

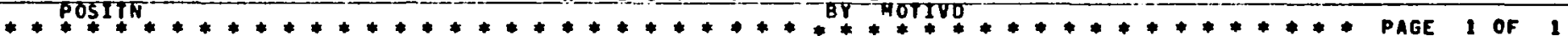

MOTIVD

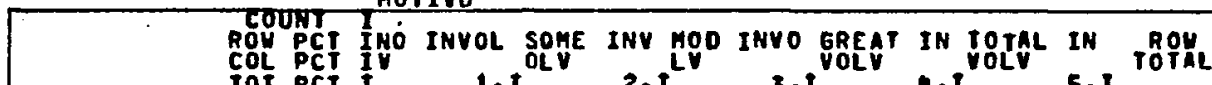

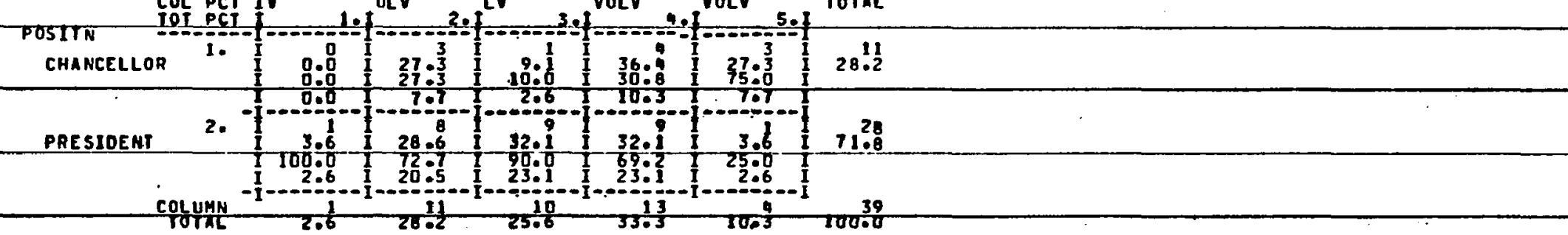

7 OUT Of 10 ( T0.0\%) OF THE VALTO CELLS HAVE EXPECTEO CELL FRE OUENCY LESS THAN 5.0.

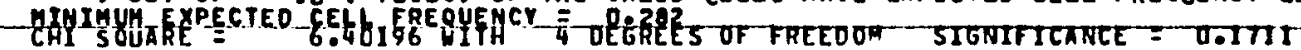


CHANCELL ORS AND PRESIOENTS SURVEY

$06 / 05 / 80$

PAGE A1

FILE NONAME (CREATION DATE $=06 / 05 / 86$ )

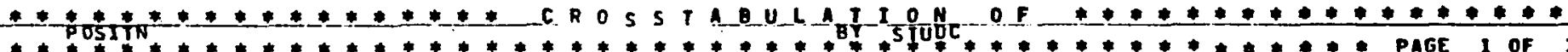

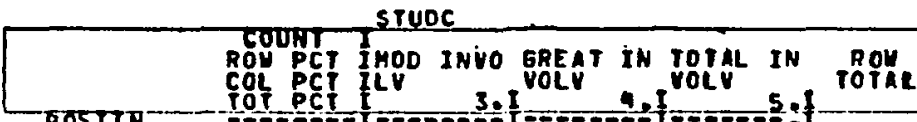

CHANCELLOR

PRESIDENT.

2.

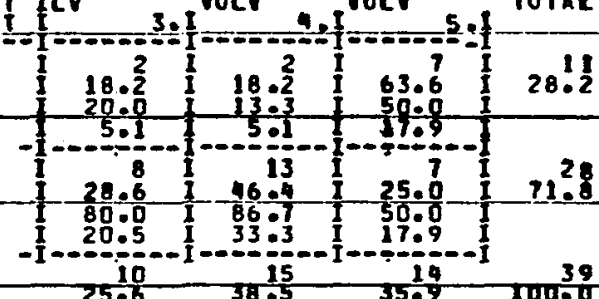

COLUMA $\frac{1-10}{25.8} 38.5$

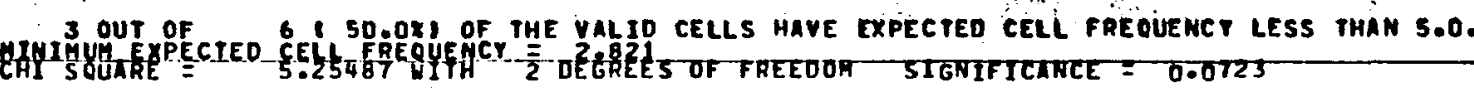

CHANCELLORS AND PRES IOENTS SURYEY

$06 / 05 / 86$

PAGE 42

\section{FILE NOMARE ICREATION DATE $=06 / 05 / 86)$}

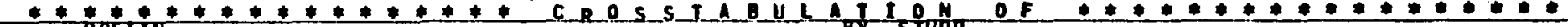

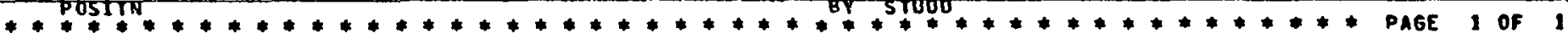
STUDO

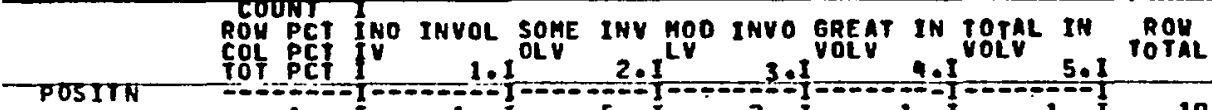

CHANCELLOR

CHANELLR

PRESIDENT

2.

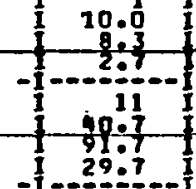

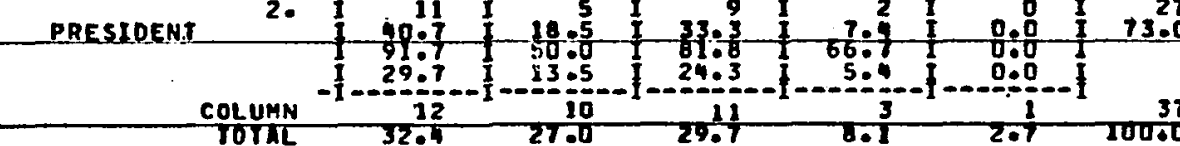

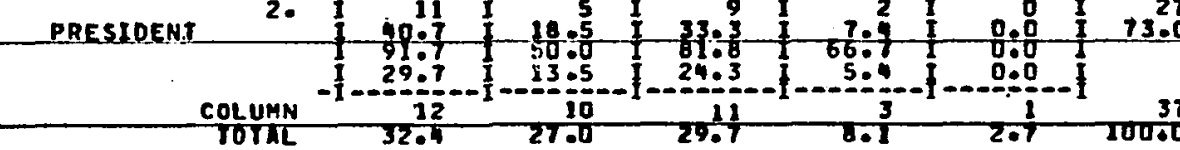

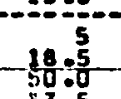

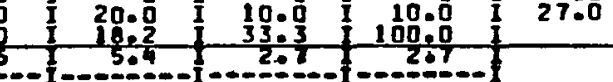

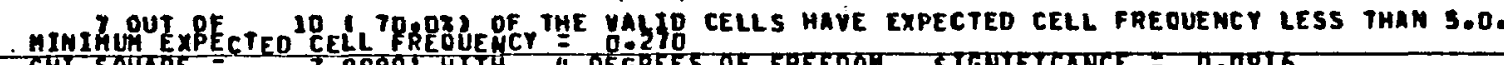

S OEGREES OF FREEDOH SIENIFICANCE $=0.0916$

NUHBER OF MISSING DQSERVATIONS $=2$ 
CHANCELLORS ANO PRESIOEHIS SURYEY

$06 / 05 / 86$

PAGE 43

FILE NOMAME ICREATION DATE = 06/05/86)

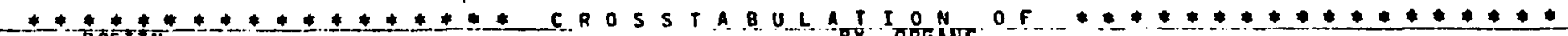

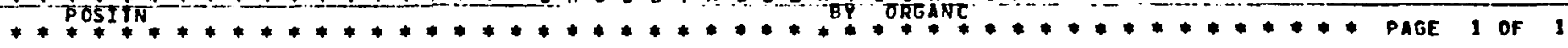

ORGANC

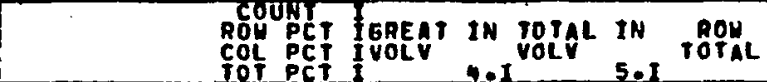

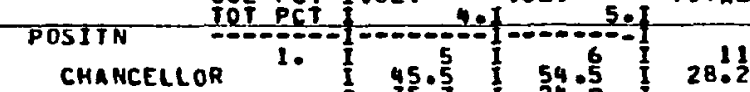

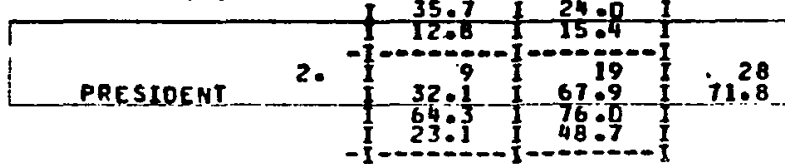

COLUHN

$35.9-64.15-100.0$

AMT OUY OF OF O 25.08 OF THE YALTD CELLS HAVE EXPECTED CELL FREQUENCY LESS THAN 5.0.

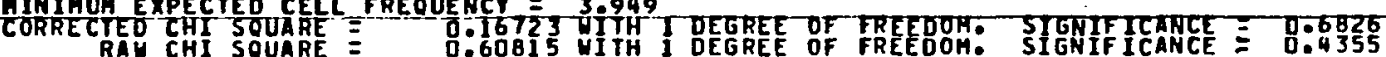

CHANCELLORS AND PRES IOENTS SURVEY

$06 / 05 / 86$

PAGE AM

FILE NONAME (CREATION DATE = 06/05/86)

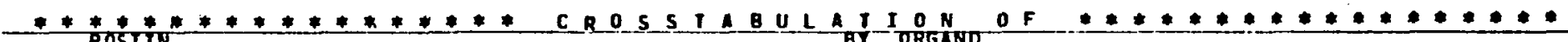

ORGANO

ROH PCT ISOHE INV MOD INVO GREAT IN TOTAL IN ROY TOL

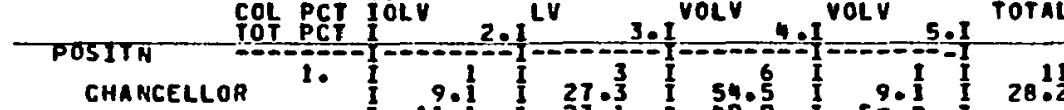

PRESTDENT 2.

COLUMN

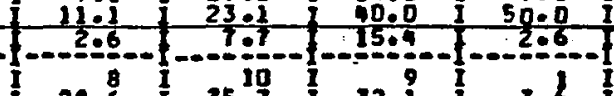

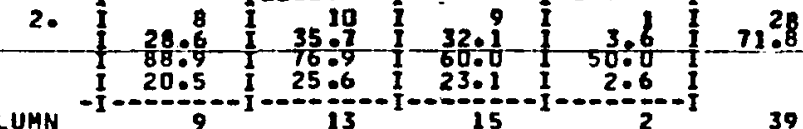

4 5 OUI OF $6162.5 \%$ OF THE YALIO CELLS HAVE EXPECTEO CELl FREOUENCY LESS THAM 5.0.

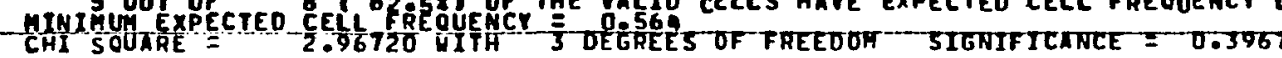


1 CHANCELLLORS AND PRESIDENTS SURVEY

$06 / 05 / 86$

PAGE 45

FILE NONAME (CREATION DATE $=06 / 05 / 861$

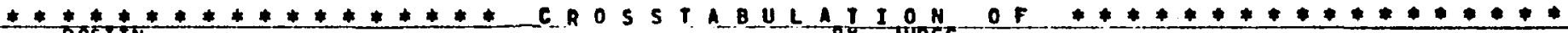

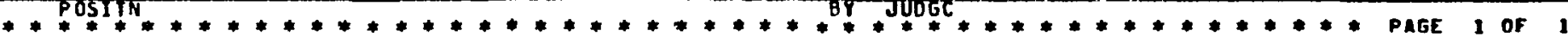
Judec

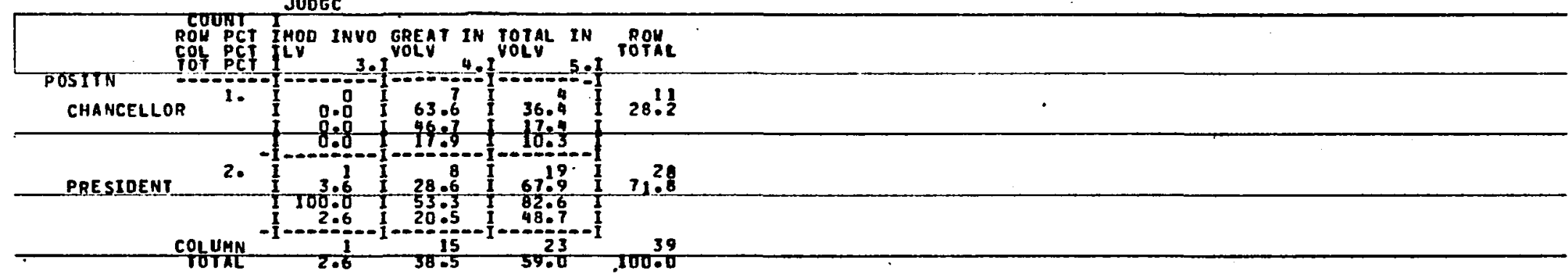

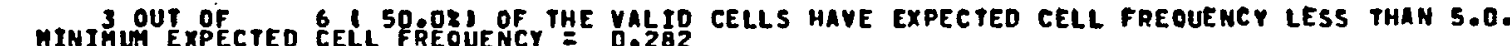

CHI SOUARE $=$ T.

CHANCELLORS AND PRESIDENTS SURUEY

$06 / 05 / 86$

PAGE 46

FILE NONARE ICREATION DATE = 06/05/86

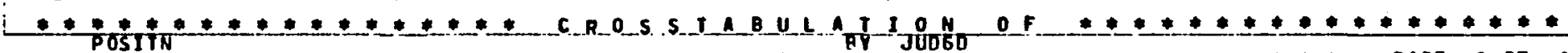

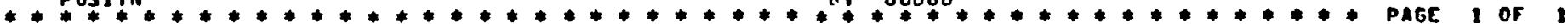

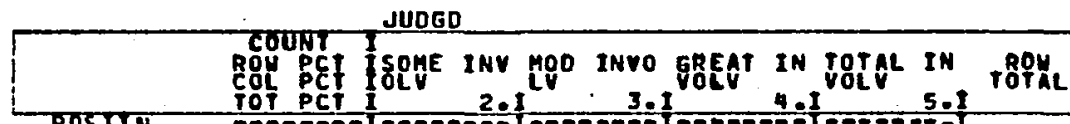

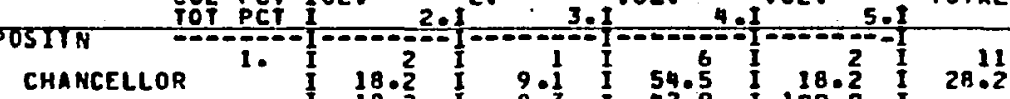

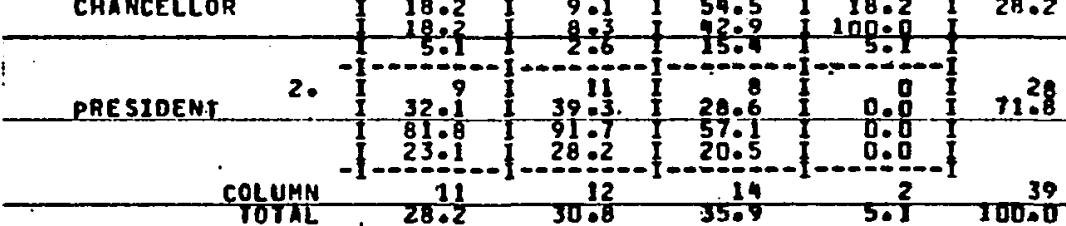

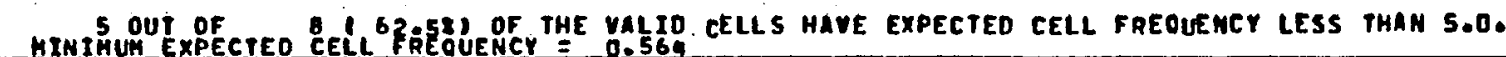

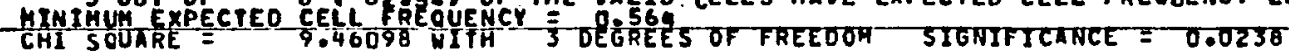


CHANCELLLORS ANO PRESIDENTS SURVEY

$06 / 05 / 86$

PAGE AT

FILE NONAME (CREATION DATE = 06/05/06)

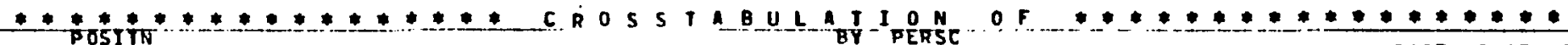

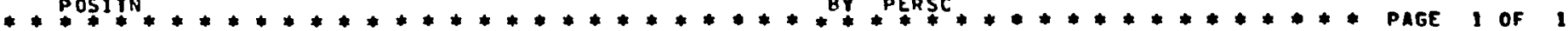

PERSC

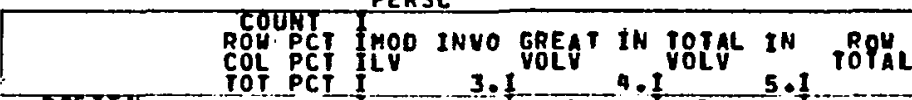

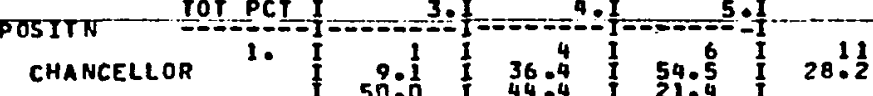

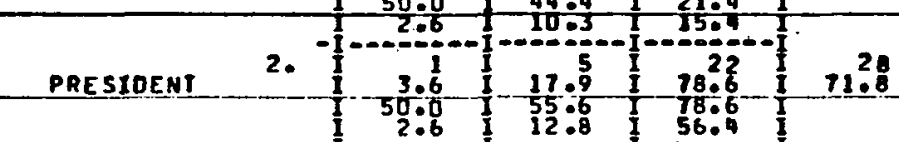

CPf

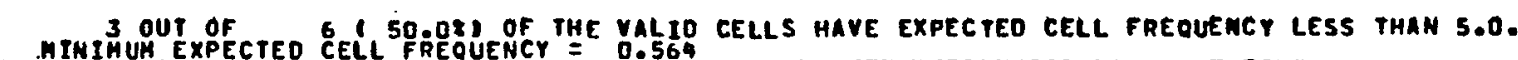

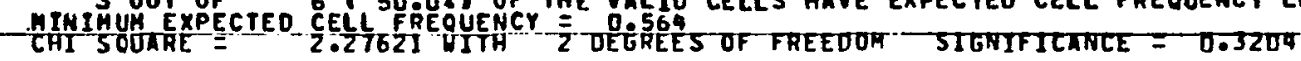

CHANCELLORS ANO PRESIDENTS SURVEY

$06 / 05 / 06$

PAGE 40

FILE NOMAHE ICREATION DATE $=06 / 05 / 86$

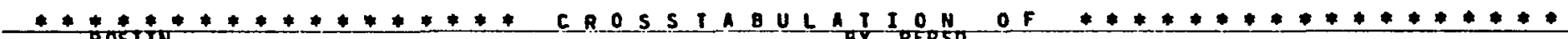

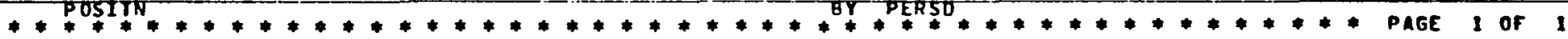

PERSD.

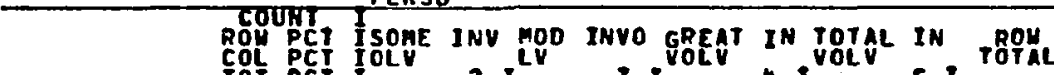

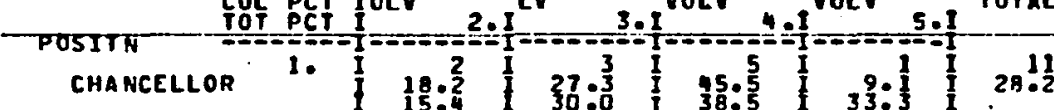

2.

PRESIOENT

CQLUAM

i.

$2-11$

$10-3303$

$13-1.8^{3} 100.00$

MIMI OUT DF

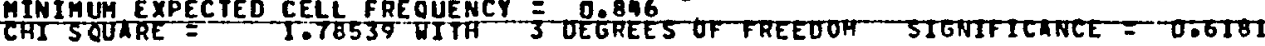




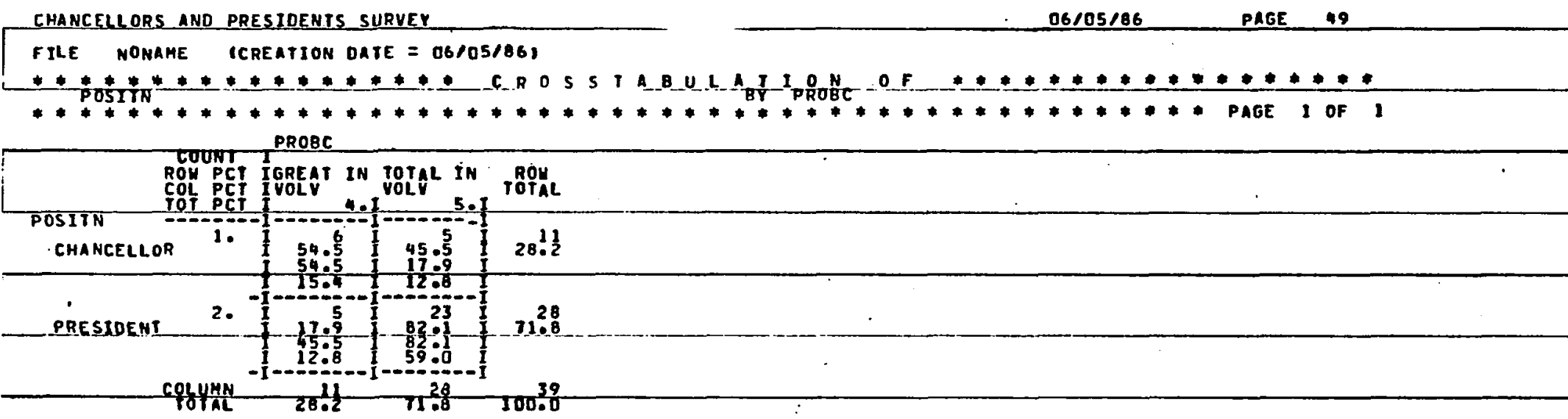

MINI DUT OF

CORAETEU CHI SOUARE

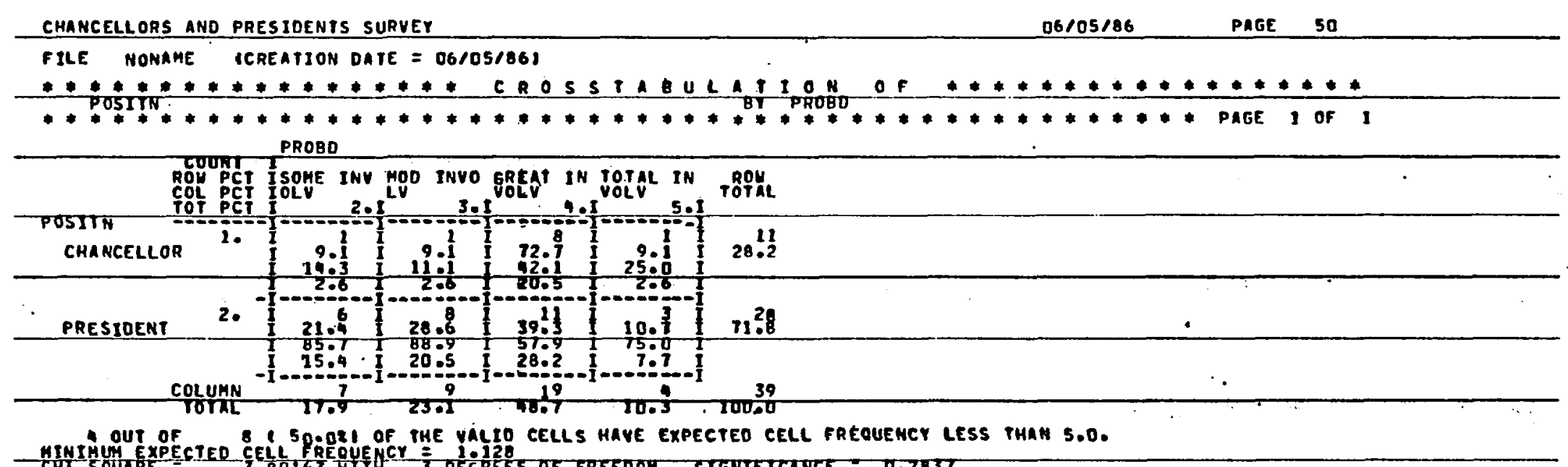




\section{APPENDIX E \\ Chancellors' and Presidents' Years of Administrative Experience in Multi-College Districts}


Chancellors' Years of Administrative Experience in Multi-College Districts

\begin{tabular}{|c|c|c|c|c|c|}
\hline Chancellor & $\begin{array}{c}\text { Experience } \\
\text { Chancellor }\end{array}$ & $\begin{array}{l}\text { Chat } \\
\text { thi }\end{array}$ & $\begin{array}{l}\text { ncellor } \\
\text { s Distr }\end{array}$ & $\begin{array}{l}\text { in } \\
\text { ict }\end{array}$ & $\begin{array}{c}\text { Total in } \\
\text { his District } \\
\end{array}$ \\
\hline \multirow[t]{2}{*}{$\begin{array}{r}1 \\
2 \\
3 \\
4 \\
5 \\
6 \\
7 \\
8 \\
9 \\
10 \\
11\end{array}$} & $\begin{array}{r}2.00 \\
13.00 \\
3.00 \\
8.00 \\
5.00 \\
0.17 \\
0.33 \\
5.00 \\
6.00 \\
4.00 \\
0.92\end{array}$ & & $\begin{array}{l}2.00 \\
8.00 \\
3.00 \\
8.00 \\
5.00 \\
0.17 \\
0.33 \\
5.00 \\
6.00 \\
4.00 \\
0.92\end{array}$ & & $\begin{array}{r}30.00 \\
8.00 \\
3.00 \\
14.00 \\
20.00 \\
1.00 \\
3.00 \\
5.00 \\
22.00 \\
10.00 \\
1.00\end{array}$ \\
\hline & $\begin{array}{l}\operatorname{an}=4.31 \\
\text { an }=4.00\end{array}$ & $\begin{array}{r}\text { Mean } \\
\text { Median }\end{array}$ & $\begin{array}{l}=3.85 \\
=4.00\end{array}$ & $\begin{array}{r}\text { Mean } \\
\text { Median }\end{array}$ & $\begin{array}{l}=10.63 \\
=8.00\end{array}$ \\
\hline
\end{tabular}


Presidents' Years of Administrative Experience in Multi-College Districts

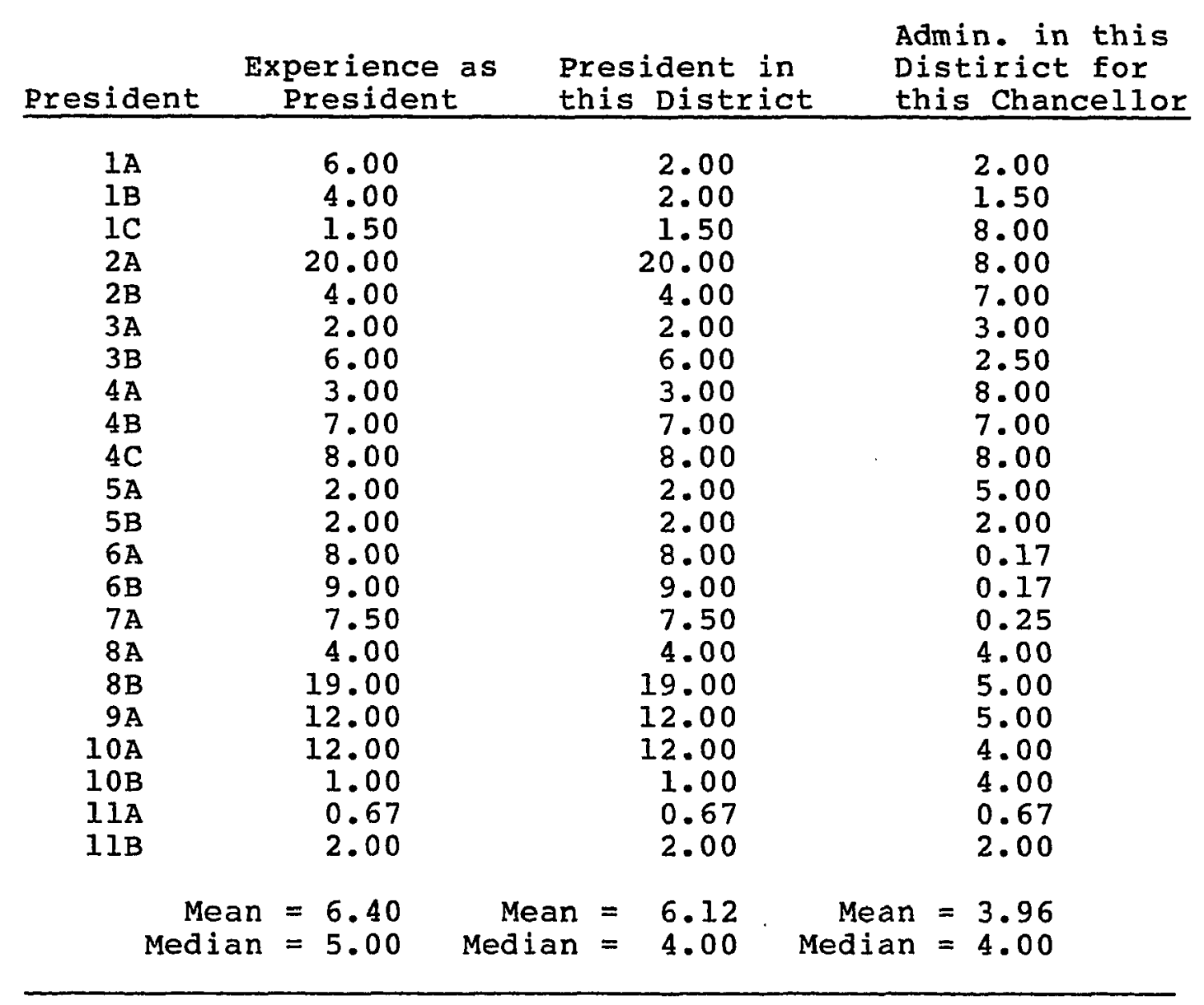


REFERENCES

162

Reproduced with permission of the copyright owner. Further reproduction prohibited without permission. 


\section{References}

ACCCA Personnel Commission (1985-86). Annual benchmark compensation study for administrative positions. Unpublished study. Association of California Community College Administrators. Pleasant Hill, California

Argyris, C. (1976). Increasing leadership effectiveness. New York: McGraw Hill.

Baldridge, J. V. (1973, May). Institutional size and professional autonomy: The death of the small college myth? (Report No. RD-Memo-109). Stanford University, California: Stanford Center for Research and Development. (ERIC Document Reproduction Service, No. ED 078785).

Baldridge, J. V. (1971). Power and conflict in the university. New York: wiley.

Bennis, W., \& Slater, P. E. (1968) . The temporary society. New York: Harper and Row.

Blankenship, L. V., \& Miles, R. E. (1968). Organizational structure and managerial decision behavior. Administrative Science Quarterly, 13, 106-120.

Block, M. H. (1970), M. V. D. An increasing dilemma for community junior colleges. Community and Junior College Journal, 40, 23-25.

Bogue, J. P. (1950) - The community college. New York: McGraw Hill.

Buckner, R. G. (1975). An investigation of the role of community college chief executive officers: A comparison of selected multicampus and multi-institution public community college districts. Dissertation Abstracts Internationa1, 36, no. $12 a, 78 \overline{26}$.

Chang, N. - K. (1978) - Organizational structure in multi-campus community junior colleges/districts. Unpublished manuscript: (ERIC Document Reproduction Service No. ED 158795).

Cohen, A. M., \& Brawer, E. B. (1982). The American community college. San Francisco: Jossey-Bass.

Cohen, A. M., \& Roueche, J. E. (1969). Institutional administration or educational leader? Washington, DC: American Association of Junior Colleges. 
Commission for the Review of the Masterplan (1986a, March). Background papers: The challenge of change. Sacramento, California.

Commission for the Review of the Masterplan (1986b, March). The challenge of change. Sacramento, California.

Dressel, P. J. (1981). Administrative leadership. San Francisco: Jossey-Bass.

Evan, W. M. (1966). The organizational set: Toward a theory of interorganizational relations. In James $D$. Thompson (Ed.), Approaches to organizational design, 173-188. Pittsburg: University of Pittsburg Press.

Gordon, R. L. (1977). Unidimensional scaling of social variables. New York: Free Press.

Gordon, T. (1955) . Group-centered leadership. Boston: Houghton-Mifflin.

Graham, R. G. (1965). The junior college presidents' job: An analysis of perceived job performance and possible influencing variables. Dissertation Abstracts International, 26, no. 4, 2010 .

Gross, N., Mason, W. S., \& McEacher, A. W. (1958). Exploration in role analysis: Studies of the school superintendency role. New York: John Wiley and Sons.

Henry, T. C., \& Creswell, J. W. (1983). The levels of decision-making in multi-unit community college systems. Community/Junior College Quarterly, 7, 115-130.

Hersey, P., \& Blanchard, K. H. (1977). Management of organizational behavior: Utilizing human resources. Englewood Cliffs, New Jersey: Prentice-Hall.

Hill, R. A. (1985). Multicampus university organizational structure and branch campus administrative problems. Dissertation Abstracts International, 46, no. 4, 858A.

Hinkle, D. E., Wiersma, W. \& Jurs, S. 9. (1979). Applied statistics for behavioral sciences. Chicago: Rand McNally.

Jenkins, J. A., \& Rossmeier, J. G. (1974). Relationships between centralization/decentralization and organizational effectiveness in urban multi-unit community college systems: A summary report. Ann Arbor: Center for the Study of Higher Education, University of Michigan. (ERIC Document Reproduction Service No. ED 110103). 
Jensen, A. M. (1965). An investigation of the administration of junior college districts with multi-campuses. Dissertation Abstracts International, 26, no. 7,3720 .

Jensen, A. M. (1984). Multicampus community colleges, twenty years later. Unpublished manuscript, San Bernardino Valley College, California.

Jones, M. O. (1968). The development of multi-unit junior colleges. Unpublished manuscript, (ERIC Document Reproduction Service No. ED 023341).

Kanter, R. M. (1983). The change masters. New York: Simon and Schuster.

Kintzer, F. C. (1984). Decision-making in multi-unit institutions of higher education. Unpublished manuscript, Institute of Higher Education, University of Florida, Gainesville.

Kintzer, F. C. (1972, January). Decision-making in the multi-unit college. Washington, DC: American Association of Junior Colleges, (ERIC Document Reproduction Service, No. ED 056687).

Kintzer, F. C., Jensen, A. M. \& Hansen, J. A. (1969) : The multi-institution junior college district. Unpublished manuscript, (ERIC Document Reproduction Service, No. ED $030415)$.

La vire, W. A. (1961). Critical tasks for public junior college administrators. Dissertation Abstracts International, 22, no. 10,3491.

Lawrence, P. R. \& Lorsch, J. W. (1967). Differentiation and integration in complex organizations. Administrative Science Quarterly, 12, 1-47.

Likert, R. (1961). New patterns of management. New York: McGraw-Hill.

Mann, F. C. (1965). Toward an understanding of the leadership role in formal organization. In R. Durbia, G. C. Homans, F. C. Mann, \& D. C. Miller (Eds.), Leadership and productivity. San Francisco: Chandler.

Mayhew, I. b. (1977). Legacy of the seventies. San Francisco: Jossey-Bass.

McGregox, D. M. (1960). The human side of enterprise. New York: McGraw Hill. 
Meeth, L. R. (1971). Administration and leadership. In H. L. Hodgkinson, \& L. R. Meeth (Eds.), Power and authority, 41-47. San Francisco: Jossey-Bass.

Morrissey, K. C. (1967) . Creative leadership of multi-unit colleges. Junior College Journal, 38, (1) 38-42.

Odiorne, G. S. (1965) - Management of objectives. New York: Pitman.

Olswang, S. G. (1977). A comparative study of role prescriptions, perceptions and performances of provosts, deans and department chairpersons. Dissertation Abstracts International, 36 , no. 3, 1161A.

Peters, T. J., \& Waterman, Jr., R. H. (1982). In search of excellence. New York: Harper \& Row.

Richman, B. M., \& Earmer, R. N. (1977). Leadership, goals and power in higher education. San Francisco: Jossey-Bass.

Richardson, R. C., Blocker, C. E., \& Bender, L. W. (1972). Governance for the two-year college. New Jersey: Prentice-Hall.

Rossmeier, J. G. (1967). Perspectives on multi-unit colleges. New Directions in Community Colleges, (4) $77-78$.

San Diego Community College District. (1982). Communications audit of managers. Unpublished study, San Diego Community College District Management Association, California.

Sayles, L. R. (1979) - Leadership: What effective managers really do and how they do it. New York: McGraw Hill.

Schein, E. H. (1985) . Organizational culture and leadership. San Francisco: Jossey-Bass.

Scigliano, J. A. (1981, July - September). Planned structural change in two-year colleges with turbulent contexts. Community/Junior College Research Quarterly, 5 , (4) $351-365$.

Shannon, W. G. (1962) . The community college president: A study of the role of presidents of the public community junior college. Unpublished doctoral dissertation, Columbia University, New York.

Stiern, W. (1985). Senate bill 2064, chapter 1506. California State Legislature, Sacramento, California. 
Tuckman, B. W. (1978) . Conducting educational research. New York: Harcourt, Brace \& Jovanovich.

Tyne, W. L. (1984). Role of the secondary school principal: A comparison of superintendents' and secondary school principals' perceptions. Dissertation Abstracts International, 45 , no. $10,3045 \mathrm{~A}$.

Van Trease, D. P. (1972). An analysis of the understanding of authority relationships between chief district administrators and chief campus administrators in multicampus junior college systems. Dissertation Abstracts International, 33, no. 11, 6040A.

Wattenbarger, J. L. (1977, Fal1). Decision-making in multi-unit districts. Community College Review, $\underline{5}$, (2) 14-21.

Wattenbarger, J. L., \& Holcombe, W. N. (1975). Central administration in multi-unit community colleges. Gainesville, Florida: Institute of Higher Education, University of Florida.

Whiting, A. N. (1980) . Restrictive aspects of centralized governance. In $H_{\text {. Delaney (Ed.), Views on system }}$ governance, 26-27. Washington, DC: Association of state Colleges and Universities.

Wynn, J. T. (1973). A study of selected aspects of centralization versus autonomy in the administration of multi-campus two-year colleges. Dissertation Abstracts International, X1973 (ERIC Document Reproduction Services, ED 082745).

Yukl, G. A. (1984). Leadership in organizations. Englewood Cliffs, New Jersey: Prentice-Hall. 